\title{
O ELEMENTO DE INTENÇÃO NAS OBSERVAÇÕES FILOSÓFICAS DE WITTGENSTEIN: FUNDAMENTOS TEÓRICOS
}

On the intentional element in Wittgenstein's “Philosophical Observations": theoretical foundations

Márcio Rodrigo Mello ${ }^{1}$

\begin{abstract}
RESUMO
O propósito deste trabalho é analisar o conceito de intencionalidade de Wittgenstein desenvolvido no texto das Observações filosóficas, esclarecer o contexto imediato do seu surgimento e localizar suas relações com a filosofia do Tractatus Logico-Philosophicus. Tal conceito aparece de modo explícito pela primeira vez no contexto do debate do autor com Russell, no qual Wittgenstein critica a visão desse autor presente na obra The Analysis of Mind, ao dizer que a concepção da relação entre pensamento e fato, segundo Russell, depende de uma relação externa, enquanto a sua própria concepção figurativa depende apenas de uma relação interna. As raízes dessa afirmação se encontram no Tractatus, no qual ele apresenta a sua concepção de "relações internas". É o objetivo deste trabalho analisar a necessidade deste "elemento de intenção" e seus fundamentos no Tractatus, para o contexto do debate com Russell e o desenvolvimento do pensamento de Wittgenstein no período intermediário de sua filosofia.
\end{abstract}

Palavras-chave: Filosofia da Linguagem. Filosofia da Mente. Intencionalidade. Verificacionismo. Wittgenstein Intermediário.

\begin{abstract}
The purpose of this work is to analyze Wittgenstein's concept of intentionality, developed in the text of the Philosophical Remarks, to clarify the immediate context of its emergence and to find its relations with the philosophy of the Tractatus Logico-Philosophicus. Such concept appears explicitly for its first time in the context of the author's debate with Russell, in which Wittgenstein criticizes the author's view present in the work The Analysis of Mind, when saying that the conception of the relation between thought and fact developed in this work depends on an external relation, while his own picture conception depends only on an internal relation. The roots of this statement are found in the Tractatus, in which he fully develops his concept of "internal relations". It is the aim of this paper to analyze the need for this "element of intention" and its foundations in the Tractatus, in the
\end{abstract}

\footnotetext{
${ }^{1}$ Universidade Federal de São Paulo.

E-mail: marciormello@hotmail.com. ORCID: 0000-0003-2488-0949.
} 
context of the debate with Russell and the development of Wittgenstein's thought in the intermediate period of his philosophy.

Keywords: Philosophy of Language. Philosophy of Mind. Intentionality. Verificationism. Middle Wittgenstein.

\section{Introdução}

O filósofo austríaco Ludwig Wittgenstein (1889-1951) é famoso não só pela sua importância no desenvolvimento da Filosofia da Linguagem, mas também pela dinâmica do seu percurso filosófico. Após chegar à conclusão de que havia resolvido todos os problemas da Filosofia (considerando-os como problemas resultantes de uma má compreensão da lógica da linguagem, ou seja, pseudoproblemas), decidiu se tornar um professor primário em uma pequena cidade. Porém, algum tempo depois começou a desenvolver um trabalho com o matemático Frank Ramsey, com o propósito de retornar à universidade de Cambridge. Ramsey, por sua vez, faz críticas relevantes à sua obra, que parecia definitiva. No contexto da revisão do seu primeiro trabalho, Wittgenstein também encontra problemas importantes que o levarão a desenvolver um pensamento novo, ainda que continue sustentando algumas concepções anteriores. E é neste período (cerca de final de 1929 e início de 1930) que suas investigações o levaram à necessidade de um "elemento de intenção, sem o qual toda a função da linguagem desmorona"2. Sustentamos que este elemento de intenção seja uma forma de intencionalidade presente na relação entre linguagem e mundo, que passa a se tornar indispensável para esse momento da filosofia de Wittgenstein. É possível encontrar o debate acerca desse elemento de intenção em um texto datilografado e enviado para Russell, com o objetivo de conseguir uma bolsa de estudos na Universidade de Cambridge: o TS 209, editado após a sua morte por Rush Rhees e chamado de Philosophische Bemerkungen (a partir daqui usaremos somente 'PB'), que pode ser traduzido como 'Observações Filosóficas'. Tal elemento nos leva imediatamente ao termo 'intencionalidade', que adquire o seu uso moderno mais conhecido a partir do pensamento de Franz Brentano. Porém, aqui não se trata simplesmente de uma adoção da concepção de consciência segundo a tradição de Brentano e Husserl:

\footnotetext{
2 WITTGENSTEIN, Ludwig. Philosophische Bemerkungen. p. 63.
} 
Wittgenstein, a partir desta época, passa a localizar a necessidade de um tipo de intencionalidade na relação entre pensamento e fato, ou seja, na sua nova concepção de figuração. Também procura evitar a todo custo qualquer forma de psicologismo, como veremos adiante. Portanto ele se limita a localizar e analisar tal elemento somente na estrutura da linguagem.

A elaboração das $\mathrm{PB}$ se insere no desmoronamento do edifício lógico do Tractatus Logico-Philosophicus ('TLP' a partir deste ponto), com o surgimento da necessidade da consideração das questões de ordem fenomenológica e da necessidade de se tratar das 'declarações de grau' que não foram plenamente abordadas nesta obra. Tais declarações se referem às proposições sobre cor, temperatura, altura e peso, por exemplo, e que colocam a necessidade de se levar em conta, na análise da linguagem, que duas cores, como o verde e o vermelho, não podem ocupar o mesmo ponto no espaço visual ao mesmo tempo. Apresentando as consequências desse problema de forma sintética, tal impossibilidade fere o método de análise das proposições elementares e o próprio princípio da independência lógica das mesmas, pois a afirmação de que um ponto é vermelho em um tempo (p) determina a falsidade da afirmação de que o mesmo ponto, ao mesmo tempo, seria verde $(q)$, deixando claro que a conjunção $p^{\wedge} q(p$ e $q)$ não poderia ser falsa, mas sim um contrassenso (nonsense). Tal problema levou Wittgenstein à necessidade de se admitir uma linguagem fenomenológica, ou "primária", que pudesse preencher as lacunas da análise da linguagem do TLP, e o levou também a tentar estruturar uma "notação complementar baseada na estrutura da experiência" ${ }^{4}$. Tal linguagem primária, além de modificar a estrutura de algumas tabelas de verdade, também utilizaria um sistema de coordenadas para descrever com precisão o espaço visual, além de um 'octaedro de cores', que permitiria entender como algumas cores podem ser combinadas, enquanto outras não. No entanto, esse projeto durou pouco, e foi abandonado no início de 1930, quando o autor se deparou com problemas relacionados à inexatidão dos dados sensoriais, com a dificuldade de se apresentar os fenômenos por meio do sistema de coordenadas e com a ambiguidade do es-

\footnotetext{
3 Id. Ibid. p. 51.

4 ENGELMANN, M. Wittgenstein's Philosophical Development: phenomenology, grammar, method and the anthropological view. p. 23-25.
} 
paço visual: alguém poderia dizer que aquilo que vê é um círculo, o que na verdade, sob o olhar do microscópio, se revelaria como uma figura de cem lados, por exemplo ${ }^{5}$. Portanto foi necessária a elaboração de um novo pensamento a respeito do funcionamento da linguagem, que não mais considerasse a prioridade de uma linguagem especificamente fenomenológica, mas que ainda assim admitisse um tipo de fenomenologia: pensamento este que foi desenvolvido principalmente nos quatro primeiros capítulos das PB. É importante notar que as PB tratam de muitos temas, que não serão abordados aqui. Elas são o resultado de uma tentativa de organização de textos anteriores, nos quais o autor ainda sustentava uma linguagem fenomenológica, e que foram modificados para apresentar um tipo de 'relatório de produção' para Russell, responsável pela avaliação do seu trabalho para a universidade. Portanto, para apresentar um texto que desse conta das mudanças pelas quais as suas ideias estavam passando, com pouco tempo, Wittgenstein alterou a ordem dos seus manuscritos, suprimindo algumas partes e acrescentando outros trechos. É o nosso propósito nos concentrarmos na análise dos quatro primeiros capítulos das $\mathrm{PB}$, nos quais podemos encontrar as declarações mais importantes a respeito desse elemento de intenção.

Um dos propósitos deste trabalho é dar continuidade à pesquisa desenvolvida em nível mestrado ${ }^{6}$, e agora prosseguida no doutorado. Essa pesquisa recebeu influência direta do trabalho dos professores Marcelo Carvalho, J. Cuter, M. Engelmann e B. Prado Neto acerca do 'período intermediário' da filosofia de Wittgenstein.

Wittgenstein apresenta um novo pensamento nas PB, explicitando as características do seu pensamento em oposição às ideias de Russell, Ogden e Richards. As críticas à Russell se endereçam à teoria causal da expectativa $\mathrm{e}$ do significado presente na obra The Analysis of Mind ('AM' a partir daqui), de 1921, enquanto as críticas contra Ogden e Richards se dirigem à obra The Meaning of 'Meaning' de 1923. No entanto, pela familiaridade das concepções presentes nessas obras, Wittgenstein se dirige, na maior parte do tempo, à Russell, ao qual ele contrapõe a sua própria concepção de figuração. Esta

\footnotetext{
${ }^{5}$ Id. Ibid. p. 35-36.

${ }^{6}$ MELLO, Marcio R. Intencionalidade nas Observações Filosóficas de Wittgenstein: o elemento de intenção, de 2015 sob orientação do prof ${ }^{\circ}$ Dr. Marcelo Carvalho pela Universidade Federal de São Paulo - UNIFESP.
} 
tem como pressuposto uma relação interna entre o pensamento e o fato, enquanto a de Russell necessita de uma relação externa, ou seja, de um terceiro elemento diferente do pensamento e do fato, exterior aos mesmos e que poderia ser um tipo de 'sentimento de satisfação'. No contexto desse debate com Russell, Wittgenstein chama a atenção para a necessidade do já citado elemento de intenção no funcionamento da linguagem.

A estrutura deste trabalho consistirá em três tópicos, para melhor compreensão do mesmo: Começaremos com uma breve exposição da concepção causal de Russell, seguida pelas críticas de Wittgenstein; o segundo tópico tratará dos pressupostos teóricos da concepção de intencionalidade das $\mathrm{PB}$, encontrados nas relações e propriedades internas entre figuração e fato explicitadas no TLP; e finalmente o último tópico será uma análise da concepção de intenção das $\mathrm{PB}$, e também da relação entre intenção e métodos de verificação de expectativas. Terminados os tópicos haverá uma conclusão geral sobre o valor dessa forma de intencionalidade nesse momento do percurso teórico do autor.

\section{A teoria causal de Russell e as críticas de Wittgenstein}

Na seção $§ 20$ das PB, Wittgenstein cita pela primeira vez a necessidade de uma intencionalidade na linguagem, ao advertir que "uma concepção errônea a respeito da linguagem pode destruir toda a lógica da mesma, e não somente causar uma mera perturbação local"'. Tal advertência é uma referência direta à teoria causal de Russell. Russell sustenta a concepção de que desejos, expectativas e crenças obedecem a certas leis causais, defendendo também que o nosso conhecimento acerca dos mesmos depende de "relações muito externas" àquelas que costumamos perceber. Para entender melhor essas relações, precisamos partir daquilo que Russell pensou a respeito do desejo, caso que deixa bem claro quais são as premissas por trás de sua visão. Segundo ele, o comportamento humano a respeito dos desejos pode ser melhor conhecido observando-se o comportamento dos animais em relação aos seus próprios desejos, como a fome, por exemplo. Para ele, nada podemos aprender a partir de nossos próprios estados mentais, mas, pelo

${ }^{7}$ WITTGENSTEIN, Ludwig. Philosophische Bemerkungen. p.63.

${ }^{8}$ RUSSELL. B. The Analisys of Mind. p. 141. 
contrário, um observador neutro poderia saber muito mais sobre o comportamento de outra pessoa do que acerca do seu. Ao observarmos o comportamento dos animais, é possível perceber que eles, ao manifestarem a necessidade de comer, andam de um lugar para o outro, inquietos, até o momento em que comem e finalmente entram em um estado de aquietação. Para Russell, esse fenômeno é comum em todos animais, inclusive no próprio ser humano, denominado como um "ciclo de comportamento". Não somos diferentes dos outros animais, mas o hábito teria a função de antecipar certos eventos que podem servir como satisfação de nossas necessidades e nos daria a ilusão cômoda da consciência dos objetos dos nossos desejos.

Nessa concepção, seres humanos e outros animais não sabem o que é capaz de dar um fim a esse ciclo de comportamento e, por isso, só podem saber o que pode satisfazer o seu desejo no final do próprio ciclo, experimentando um tipo de 'sentimento de satisfação'. Russell afirma que, por mais que pensemos ter certeza acerca do que desejamos, não é assim que se passa na realidade: todos os desejos são conhecidos pela experiência, ou seja, um animal só consegue saber qual alimento poderá satisfazer sua fome depois de comê-lo. Se sempre soubéssemos o que desejamos, então como poderíamos nos enganar tantas vezes com relação ao que realmente queremos?

É possível entender que a relação aqui estabelecida entre desejos e suas realizações depende de um terceiro acontecimento exterior à ambos: experimentar um tipo de sensação de satisfação, que teria o papel de confirmar que o evento em questão (comer determinado alimento) pôde ser a realização do desejo da fome, por exemplo. Esse tipo de relação externa entre um desejo e sua realização também se encontra na concepção de Russell a respeito das crenças e do significado na linguagem. As crenças são consideradas aqui pelo filósofo como sentimentos, e se dividem em três tipos: memórias, que se referem aos eventos do passado, expectativas, que se referem aos eventos do futuro, e o assentimento, que se refere ao presente. Crenças possuiriam um conteúdo, que pode ser formado por palavras, imagens e sensações, e também um objetivo, que são os fatos. Estes últimos seriam exteriores aos conteúdos das crenças, e também seriam, para Russell, as

9 Id. Ibid. p. 36-37. 
referências das crenças verdadeiras ${ }^{10}$. Aqui o maior problema está na concepção de expectativa: como é possível saber que uma expectativa foi realizada? Segundo Russell, isso só é possível no momento da sua realização, ao se experimentar também uma sensação de satisfação. Se há algum tipo de comparação possível, seria apenas entre esse sentimento de satisfação com um certo "sentimento de expectativa" (AM p.163), experimentado na origem da mesma. O processo ocorreria da seguinte forma: a expectativa, como afirmado acima, é um tipo de crença. Fazem parte do conteúdo da crença também sentimentos associados. Ao se ter uma expectativa de que 'vai chover hoje a tarde', geralmente formamos na mente imagens da chuva caindo, nuvens escuras, sons característicos de chuva, bem como também sentimentos em relação à mesma (ela pode ser esperada com medo ou alegria, por exemplo). O problema está em se saber como a imagem que alguém formou da chuva, no momento da expectativa, pode ser comparada com o que se vê agora. Segundo Russell, para que um evento possa ser comprovado como a realização dessa expectativa, devemos comparar o sentimento que se experimentaria no momento de satisfação, concomitante ao próprio evento, com a lembrança do provável sentimento experimentado na origem da expectativa (AM p.163). Se o sentimento experimentado no momento da realização está relacionado à lembrança do sentimento original e se a pessoa agiu de forma condizente com o comportamento de quem vê realizado algo que espera, então, segundo ele, chegamos ao "máximo da verificação"". Sendo assim, essa forma de verificação, segundo o próprio autor, se fundamenta em uma relação externa, na qual uma sensação cumpre o papel de ser o 'significado' da expectativa.

Concluindo a exposição do pensamento de Russell, é importante notar o modo como esse autor entende a função da linguagem e o modo como as palavras adquirem significado. Segundo ele, "o uso de uma palavra vem primeiro, e o significado deve destilar-se dele, por meio da observação e da análise" ${ }^{\prime 2}$, ou seja, o significado de uma palavra aqui também é conhecido

\footnotetext{
${ }^{10}$ ENGELMANN, Mauro. A Crítica a Russell: os capítulos II, III e IV das PB in CARVALHO. M. et al. Fenomenologia, Análise e Gramática: comentário às Observações Filosóficas de Wittgenstein. p. 66.

11 RUSSELL. B. The Analisys of Mind. p. 163.

12 Id. Ibid. p. 118.
} 
por sua eficácia causal, segundo os efeitos que pode causar no ouvinte (AM p. 118). Russell distingue quatro formas de se entender as palavras: em primeiro lugar, pelo seu uso apropriado em cada situação (de forma a não causar estranhamento nos ouvintes), em segundo, na maneira como as palavras são capazes de causar certos comportamentos no ouvinte; em terceiro lugar, quando fazemos uma associação com palavras de outro idioma e, por último, quando ela é associada a algum objeto, principalmente nas situações em que se ensina um nome apontando-se para um objeto e falando a palavra com a qual o nomeamos (AM p.119). Portanto, as palavras são definidas pelo efeito que podem causar para se alcançar certos resultados. E isso pode acontecer mesmo que os objetos não estejam diante daquele que fala: outros dois usos das palavras podem ser, segundo Russell, de suscitar lembranças no ouvinte ou um uso narrativo, o qual tem o objetivo de causar a produção de imagens fantasiosas no ouvinte (AM p.120). Por isso, da mesma forma que nos casos anteriores, as palavras também estariam submetidas às leis causais que citamos anteriormente (AM p.118).

O nosso segundo passo neste primeiro tópico consiste em fazer uma exposição das críticas de Wittgenstein acerca da teoria causal de Russell, tomando como referência o capítulo III das PB. A teoria de Russell ataca exatamente as colunas de sustentação da linguagem, e é contra a teoria de Russell que Wittgenstein se posiciona. Nesse momento o autor trata de contrapor a sua teoria à de Russell: enquanto a concepção de Wittgenstein depende apenas de uma relação interna entre figuração e fato, na concepção de Russell faz-se necessário um terceiro elemento além desses, ou seja, um sentimento que dê sentido à própria expectativa. Wittgenstein afirma que este sentimento de satisfação é irrelevante e descartável. Dessa forma, somente duas coisas devem ser necessárias: o pensamento e o fato. Tal sentimento de satisfação não é simplesmente um acessório acrescentado nesta relação: o seu maior problema consiste na sua possibilidade de ser um critério de atribuição de sentido à própria expectativa.

De acordo com o pensamento de Wittgenstein em 1930, proposições são hipóteses que devem ser verificadas segundo determinados critérios, tais como a observação direta e o uso de instrumentos de medida, por exemplo. Portanto nas PB as proposições são pensadas como expectativas: se alguém 
dá uma ordem, então espera que a mesma seja cumprida, ou se alguém deseja algo, também tem a expectativa de alcançar o objeto do seu desejo, e se alguém diz que há uma mancha vermelha no carpete, também espera que essa descrição corresponda a esse fato descrito, por exemplo. Então se alguém tem uma expectativa, a mesma deve ser definida. Não é possível pensar em uma expectativa na qual não se sabe o que se espera. Segundo as regras gramaticais da linguagem, ou seja, segundo a sua estrutura, o sentido de uma proposição (e de uma expectativa, por conseguinte) deve ser anterior à sua possibilidade de ser verdadeira ou falsa. Nos moldes de Russell, o sentido de uma expectativa, ou desejo, só pode ser conhecido depois da verificação da sua verdade ou falsidade. Russell afirma também que, em muitos momentos só sabemos que uma expectativa não foi realizada no momento de sua frustração (AM p.146), ou seja, esse tipo de visão a respeito do funcionamento da expectativa não causa apenas uma mera perturbação, mas ataca o próprio princípio da anterioridade do sentido da proposição e da sua bipolaridade, já expostas no TLP. O que Russell põe em risco aqui é a própria possibilidade de sentido da proposição. Ele inverte um dos princípios fundamentais do pensamento de Wittgenstein desde o TLP: pressupõe que a verdade de uma proposição, ou de uma expectativa, anteceda o seu sentido. $\mathrm{Na}$ teoria causal de Russell, alguém só poderá saber qual era a sua expectativa ou desejo depois de experimentar um sentimento de satisfação, ou seja, depois da 'confirmação' de sua verdade. Em alguns momentos das PB Wittgenstein deixa esse problema bem claro: Na seção \$29 ele reforça a ideia de que o evento que realiza a expectativa é uma resposta suficiente a ela, não sendo necessário supor qualquer outro evento. Colocar isso em dúvida seria como colocar em dúvida o próprio sentido da expectativa. Segundo Wittgenstein, somente duas coisas são necessárias para a conexão entre expectativa e o evento: a própria expectativa e o evento esperado (PB §21). Uma relação interna deve estar estabelecida entre ambos para que se possa compreender o sentido da expectativa. É nesse sentido que o autor afirma, na seção §26, que deve existir uma conexão interna antes mesmo de uma externa. Segundo o que o autor afirma no TLP, uma relação externa é contingente, enquanto uma relação interna é logicamente necessária. Se tal relação interna pudesse ser considerada falsa, a própria proposição não teria sentido. 
Aqui uma expectativa é pensada de modo que se encontra indissociavelmente ligada ao seu evento correspondente.

É possível fazer um mapeamento das principais críticas de Wittgenstein a Russell nesse momento. Para isso me apoio no trabalho realizado por Mauro Engelmann ${ }^{13}$ e também na leitura do capítulo III das PB. Nesse capítulo Wittgenstein reduz ao absurdo a teoria de Russell em dois momentos do parágrafo $\S 22$. De modo irônico ele afirma que, se alguém quisesse comer uma maçã e levasse, em vez disso, um soco no estômago que fizesse cessar a fome, então deveria ser isso o que a pessoa realmente queria (o soco). Ora, não se trata aqui apenas de uma interrupção acidental de um ciclo de comportamento, mas do próprio sentido do desejo específico de se comer uma maçã. Mais uma vez é importante lembrar que não se trata de se entender um processo psicológico, porém de se perguntar como é possível que a proposição 'eu desejo uma maçã' possa significar outra coisa além de se desejar uma maçã? Esse mesmo problema aparece de outra forma no mesmo parágrafo: se alguém der uma ordem para alguém e essa pessoa fizer algo que deixou a primeira feliz, então era exatamente isso, segundo o modo de pensar de Russell, que ela realmente queria (PB §22). No entanto, não é possível afirmar isso somente pelo sentimento causado na pessoa solicitante. Imaginemos um exemplo: um chefe de fábrica pede para o seu funcionário comprar algumas ferramentas com o dinheiro do caixa da empresa para o seu setor. O funcionário volta com as ferramentas, que ele comprou com dinheiro roubado, e deixa o seu chefe (que não sabe do ocorrido) feliz. Neste exemplo o sentimento de satisfação do patrão não é suficiente para se saber se a expectativa foi realizada. O sentimento de satisfação, dessa forma, não é capaz de ser um critério fiel para a verificação das nossas expectativas pois, se tal fosse o caso, este sentimento poderia nos dar a certeza de que a mesma foi cumprida, sem que a mesma o tivesse sido (como no exemplo da compra das ferramentas). Um exemplo semelhante poderia ser usado para mostrar um conflito de critérios, segundo a teoria causal: o

\footnotetext{
${ }^{13}$ Especificamente em ENGELMANN. Mauro. A Crítica a Russell: os capítulos II, III e IV das PB. In CARVALHO. M. et al. Fenomenologia, Análise e Gramática: comentário às Observações Filosóficas de Wittgenstein. p. 69-79. ENGELMANN, M. Wittgenstein's Philosophical Development: phenomenology, grammar, method and the anthropological view. p. 69-76.
} 
funcionário poderia realmente comprar as ferramentas com o dinheiro do caixa, mas por um preço muito mais caro do que o chefe esperava, fazendoo experimentar uma grande decepção. Sendo assim, qual sentimento deveria ser levado em conta? A alegria pela compra das ferramentas ou a decepção por causa do preço? Aqui a ordem é dissolvida, de forma que ela foi cumprida e não o foi ao mesmo tempo, se o critério for apenas o sentimento. A teoria de Russell também implica em uma regressão ao infinito. Segundo Wittgenstein, para que alguém pudesse ter um sentimento de satisfação da expectativa, então também deveria ser necessário reconhecer que se experimentou aquela sensação (PB §22). Portanto, seria necessário outro critério de reconhecimento para o reconhecimento anterior, e assim até o infinito. Não seria possível saber se a expectativa foi realmente realizada ou não.

A falta de especificidade que leva à indeterminação das expectativas na teoria de Russell fere, como dissemos, o princípio da independência do sentido das proposições com relação à sua verdade ou falsidade (PB §23). É preciso que deva ser possível "antecipar", por meio da expectativa, a ocorrência de algum fato e, portanto, de se fazer uma figuração, independente da mesma ser verdadeira ou falsa (PB §34). A comparação entre figuração e fato "não está presente na teoria de Russell” (PB §23), ou seja, não é relevante. Para Wittgenstein, a expectativa de que o evento ' $p$ ' aconteça é realizada pelo evento ' $p$ ' acontecer, e não pelo acontecimento de um evento completamente diferente de 'p' (PB §25).

A principal falha de Russell foi, portanto, sustentar uma dependência de uma relação externa entre pensamento e fato, enquanto somente se faz necessária uma relação interna. No entanto, é necessário notar que as os termos 'relação interna', assim como 'propriedade interna', já desempenharam uma função importante no TLP. Portanto, se faz necessário um retorno a essa obra para localizar o modo como esses termos foram utilizados, e também para se entender como a distinção entre 'interno' e ‘externo' nas PB sofreu influência da importância que possuía no TLP e quais características dessa distinção se conservaram. A partir dessa necessidade, analisaremos, a seguir, a importância das relações e propriedades internas presentes no TLP, para um melhor entendimento acerca das concepções de figuração, expectativa e intenção nas PB. 


\section{A concepção de relações internas e seus pressupostos no TLP}

No início da exposição do pensamento de Russell e de sua crítica por Wittgenstein na seção $§ 21$ das PB é possível notar que o autor se fundamenta no que ele chamou de 'relações internas' entre pensamento e ação, ou seja, entre a figuração e o evento que é figurado. O autor afirma que não é necessário nada mais do que o pensamento e o fato, e que ambos estejam em relação interna, de forma a não haver dúvidas sobre a conexão entre eles, para que seja possível que proposições, enquanto hipóteses, tenham a sua confirmação no próprio fato. Sem apelar para um terceiro evento alheio, o filósofo busca sua certeza em um fundamento lógico-gramatical próximo daquele que podemos encontrar no TLP, porém sem recorrer à concepção de 'forma lógica'. É deste fundamento que vamos tratar agora.

Wittgenstein define o que ele chamou de relações e propriedades internas a partir da sentença 4.123 do TLP, onde ele afirma que uma propriedade é interna se é indispensável para algo, de forma que não possa sequer ser pensada sem ela. De igual forma uma relação é interna se for impensável que seus componentes (dois objetos, por exemplo) não estejam nesta relação ${ }^{14}$. Diferente das relações internas, as relações externas entre objetos em estados de coisas podem ou não estar presentes, ou seja, podem ser verdadeiras ou falsas e, por isso, podem ser descritas pela linguagem, enquanto as relações internas não. São justamente estas últimas que tornam possível que se possa descrever a realidade por meio da linguagem, pois há, entre a estrutura da proposição e suas partes constituintes, relações internas que espelham as relações internas entre os fatos e suas partes. Portanto são as relações internas entre proposição e fato que permitem as relações externas. Se imaginarmos, por exemplo, duas pessoas: Pedro e João, um ao lado do outro, podemos perceber uma relação externa se João estiver à direita ou à esquerda de Pedro, pois tanto uma situação quanto a outra são contingentes. Porém, se Pedro tem 1,86 m e João 1,79 m, então aqui há uma relação interna entre ambos, pois não é pensável, e nem possível (TLP 3.02), que os dois possam estar em uma relação diferente, ou seja, não é possível que João esteja em uma relação na qual ele seja mais alto do que Pedro. Dessa forma,

14 WitTGEnSteIN, L. Tractatus Logico-Philosophicus. p. 181. 
relações internas, além de serem condições para qualquer figuração possível, também fazem parte da própria estrutura lógica da figuração. Tais relações são necessárias e tornam possível a figuração, por serem as mesmas relações presentes entre fatos e estados de coisas, entre estados de coisas e seus objetos e, finalmente, entre os objetos em suas relações uns com os outros em estados de coisas (TLP 2.0123, 2.01231 e 3.24). É possível notar, portanto, uma conexão entre relações internas e aquilo que o autor afirma sobre forma lógica. É possível para a linguagem, e também para qualquer forma de figuração lógica, representar os fatos da realidade (sejam eles verdadeiros ou falsos) desde que ambos possuam a mesma forma lógica. Um exemplo relevante aparece a partir de 4.0141: uma escrita musical em uma partitura pode ser convertida na execução sonora da própria música, que por sua vez pode ser convertida em sulcos de um disco (e atualmente também pode ser convertida em dados, em um arquivo de mp3). Isso é possível porque todas essas formas de expressão musical estão em relação interna, de forma que uma possa ser a figuração da outra. No entanto, a forma de afiguração destes não pode ser descrita e nem explicada, mas pode ser apenas exibida neles (TLP 2.172).

É a combinação dos elementos da proposição, ou seja, sua forma lógica de afiguração, que reflete como um espelho, a forma lógica dos fatos. Mais especificamente reflete o modo como os elementos dos fatos se combinam. No entanto, as relações internas que tornam isso possível não podem ser descritas, pois elas são condições da própria linguagem (TLP 5.131). Falar sobre as mesmas só seria possível com outra linguagem 'acima' da nossa, o que também se revelaria impossível, pois qualquer linguagem que pudesse descrever a forma lógica também deveria pressupor a estrutura que deve explicar. E mesmo que isso fosse possível, incorreríamos em uma regressão ao infinito, pois qualquer linguagem que pretendesse explica-la precisaria também se estruturar em outra forma lógica que, por sua vez, também deveria ser explicada, e assim por diante. Portanto ressaltamos aqui que, tanto as relações e propriedades internas, por espelharem a forma lógica comum entre linguagem e mundo, quanto as propriedades internas, que permitem a multiplicidade das combinações possíveis dos nomes e objetos, 
não podem ser explicadas, mas simplesmente estão presentes e não podem ser negadas.

Voltaremos agora para o texto das PB: O capítulo III se refere diretamente às relações internas, tal como foram explicitadas no TLP, porém, com uma concepção mais ampla de figuração. Neste momento o autor passa a considerar também proposições na forma de expectativas, desejos, comandos, e não somente descrições de estados de coisas. Uma diferença fundamental que começa a se tornar mais importante é a utilização de objetos de medida como parte da linguagem, ou como instrumentos para a verificação das nossas expectativas ou descrições, tais como modelos de cores (PB $\S 38)$, réguas (PB §40) e fitas métricas (PB §33), por exemplo ${ }^{15}$. Apesar disso, o fundamento dessa nova concepção de figuração pressupõe muitos fundamentos teóricos do TLP, apesar da negação tanto da independência das proposições elementares ${ }^{16}$, quanto da necessidade de uma forma lógica comum entre figuração e fato; ainda assim é necessário que a proposição e o evento estejam em relação interna, de forma a não ser pensável que entre eles não exista tal relação. Um ponto importante a ser lembrado nesta relação explicitada por Wittgenstein é a já citada anterioridade do sentido de uma expectativa, de modo que é possível saber qual é o evento que realiza a expectativa antes mesmo de sua realização. Ao contrário do que Russell pensava, o sentido da expressão de expectativa não é algo que emerge depois de certa reação, mas já está presente na própria expectativa (ou seja, em sua descrição) o evento que a realiza. Se a teoria de Russell fosse verdadeira, então alguém poderia ter um estado, ou um pensamento, sobre o qual não fizesse a menor ideia, de maneira que não soubesse se é uma expectativa, ou um desejo, ou uma recordação, etc. Wittgenstein afirma que é possível saber que as expectativas, proposições descritivas, desejos e quaisquer figurações estão relacionadas à realidade porque podemos saber o que esperamos, o que desejamos, do que temos medo, por exemplo (PB §35).

\footnotetext{
${ }^{15}$ ENGELMANN, Mauro. A Crítica a Russell: os capítulos II, III e IV das PB in CARVALHO. M. et al. Fenomenologia, Análise e Gramática: comentário às Observações Filosóficas de Wittgenstein. p.101-104.

${ }^{16}$ WITTGENSTEIN, L. Philosophical Remarks. p. 317, "Yardsticks and System of Propositions" e p. 109-111, §82.
} 
Porém, resta ainda a pergunta: como seria possível comparar um evento que aconteceu agora com uma expectativa anterior? Se alguém espera ver uma mancha azul, como poderia saber que aquele azul é o mesmo que esperava antes (PB §28)? Wittgenstein afirma que "a descrição de uma expectativa por meio daquilo que se espera é dar uma descrição interna dela" (PB §29). Isso significa que é possível saber se determinado evento é a realização de uma expectativa quando a descrição da mesma corresponder à descrição do evento que a realiza. Wittgenstein torna esse ponto explícito na seção §30, ao afirmar que a descrição da expectativa acontece com o mesmo símbolo utilizado para descrever a sua realização. Dessa forma, se alguém tem a expectativa de que o evento descrito pela proposição ' $p$ ' aconteça, a expressão de sua expectativa deve necessariamente utilizar o símbolo ' $\mathrm{p}$ '. Isso mostra que expectativa e evento já estão em relação interna, pois ambos são descritos da mesma forma. Segundo Wittgenstein, essa simetria no uso dos signos já mostra que nada mais é necessário nessa relação, e que a descrição da expectativa já a define, já que essa descrição não poderia ser pensável sem a descrição do evento que a realiza. Dessa forma, não é necessário qualquer outro evento. Na seção $§ 25$ o autor deixa claro também esse critério: o estado de coisas que realiza a expectativa de ' $p$ ' é representado pela proposição 'p'. Portanto, é possível concluir que a expectativa é definida pelo evento que a realiza, de modo que a expectativa é sempre direcionada a algo. Isso mostra que ambas estão em relação interna, tal como o autor afirmou na seção §21c. Conforme dissemos, essa relação interna se mostra especialmente significativa no fato de que a estrutura gramatical da proposição que descreve a expectativa está em relação interna com a estrutura da proposição que descreve o evento que a realiza. Dessa forma, se alguém tem a expectativa de 'ver uma mancha azul no tapete', também terá a certeza da realização dessa expectativa, se puder comparar a proposição 'vejo uma mancha azul no tapete' com a proposição que expressa a sua expectativa 'espero ver uma mancha azul no tapete'. A relação interna entre expectativa e evento pode ser mostrada na linguagem, pois a mesma estrutura gramatical da proposição pode ser usada para descrever tanto a expectativa quanto o evento. 
Até aqui foi possível perceber o quanto ainda se mostrou fundamental a concepção de 'relações internas', presente no TLP, na estruturação do pensamento desenvolvido nas $\mathrm{PB}$. Wittgenstein a pressupõe na sua crítica à Russell, e a partir dela corrige muito problemas que colocavam em risco o entendimento da estrutura da gramática e de seu funcionamento. Diferente de sua concepção anterior, que pressupunha a estrutura lógica da linguagem em consonância direta com a estrutura lógica do mundo, o autor agora expõe uma concepção mais aberta acerca da relação entre linguagem e mundo, fundamentando-se na importância dos critérios de verificação e no papel da intencionalidade, também indissociável de sua nova concepção figurativa. No próximo tópico analisaremos o elemento de intenção da linguagem e sua relação com a gramática e com a figuração.

\section{Um elemento de intenção na linguagem}

Este tópico pretende ser ao mesmo tempo uma apresentação das características do elemento de intenção presente nas PB e uma conclusão geral deste trabalho. Ainda na seção §21 o autor afirma que, o que é essencial à intenção é a figuração daquilo que se intenta, ou seja, daquilo que se "tem em vista” (PB §21). Apesar de estarem ligadas, a intenção não é a própria figuração em si, mas ela está implícita no modo como se compara a figuração e o fato. E este 'como' é muito importante, pois chama a nossa atenção para a importância que o método de verificação de nossas expectativas, desejos e instruções adquire neste momento. O ponto principal aqui é que, da mesma forma que nas relações internas, a intenção também já está impressa no modo como se compara figuração e realidade. A importância desse modo de comparação aparece muitas vezes no texto das PB associado a tudo aquilo que o autor considera como métodos de verificação. Um exemplo se encontra na seção $\$ 27$, onde ele diz que o significado de uma pergunta é o método de se verificar a sua resposta, ou seja, significa saber como verificar a realização de uma expectativa. Assim sendo, é necessário saber o que se procura (PB §28) e "dirigir a atenção" (PB §35) para aquilo que pode realiza-la, de forma a se "preparar" (PB §33) para o evento que a realiza. Segundo Wittgenstein, a intenção está implícita na maneira como alguém, por 
exemplo, procura por um livro na estante, quanto se tem a expectativa de que o livro ainda esteja lá, de que não foi perdido ou emprestado, etc. Dessa forma, alguém que espera encontrar o livro 'Dom Casmurro', de Machado de Assis, deve se dirigir à estante, no local onde costuma guardar os livros desse autor, passando os olhos pelos livros até encontrá-lo. Em outro exemplo, se alguém procura um livro perdido, pode olhar em gavetas ou até embaixo da cama; ou se procura um livro emprestado pode se sentar e tentar se lembrar de quem o tomou emprestado, ligar para a pessoa, etc. Portanto, diferentes ações podem ser admitidas como métodos de verificação e, por isso, a intenção não pode ser a própria figuração (PB §24), mas precisa estar implícita na maneira como alguém procura verificar sua expectativa. Existe aqui uma grande diferença entre dirigir o olhar à uma estante para procurar um livro, ou conversar com um amigo ao telefone, para perguntar por um livro emprestado, por exemplo.

Para se entender melhor o elemento de intenção apresentado nas PB é importante retornar ao capítulo I: nele o autor começa a destacar a necessidade da sua concepção de gramática e a explicitar a estrutura da linguagem a partir das suas regras implícitas. Tais regras são arbitrárias e não é possível explicar o sentido das mesmas, pois, caso isso fosse possível, precisaríamos de outras regras que fossem pressupostas nas proposições, que explicariam o sentido das primeiras regras, e assim em uma regressão infinita (PB $§ 4$ e §7). Nesse momento do pensamento de Wittgenstein não há mais uma forma lógica da linguagem refletida na forma lógica do mundo, mas apenas a gramática, ou seja, conjuntos de regras, a partir das quais se estruturam diferentes linguagens. A tarefa da análise da linguagem aqui é "separar aquilo que é essencial daquilo que não é" na linguagem e "mostrar as engrenagens que giram em falso" (PB §1b), descrevendo e comparando "diferentes classes de linguagem" (PB §1c) e excluindo aquilo que não é essencial para se descrever o mundo. Não se trata aqui de procurar uma linguagem ideal (PB §3) ou de se procurar por uma "linguagem fenomenológica" (PB §1) como no início de 1929, mas de analisar a gramática da própria linguagem ordinária, procurando entender a sua estrutura implícita e o modo como a mesma pode ser uma figuração da realidade. Nessa gramática é possível encontrar diferentes espaços que correspondem ao modo como usamos as palavras em 
diferentes situações. Como já vimos anteriormente, podemos encontrar nela o 'espaço das cores', o 'espaço do som', o 'espaço da sensação de dor', o espaço do 'leve ou pesado', ou da 'altura', por exemplo ${ }^{17}$. Tais espaços poderiam ser considerados como "capítulos da nossa gramática" (PB §3). As palavras possuem possibilidades de combinação em diferentes contextos gramaticais e o significado das mesmas só existe no modo como são usadas nestes mesmos contextos. Nesse momento o autor resgata sua concepção contextualista acerca da linguagem, que aparece na sentença 3.3 do TLP, na qual afirma que um nome só tem significado no contexto da proposição. Essa concepção também aparece nos parágrafos $\S 12$ e $§ 14$ das PB: palavras são como peças de um jogo de xadrez (PB §18), ou como alavancas com diferentes funções: da mesma forma que as peças só têm o seu uso no contexto do jogo e as alavancas no contexto da estrutura da máquina, as palavras também só têm significado no seu contexto segundo as regras gramaticais, em seus espaços.

A conclusão a que podemos chegar é a de que há uma intenção no modo como os sinais, ou seja, as palavras são combinadas nos seus respectivos contextos ou espaços da gramática para se obter uma proposição com sentido. $\mathrm{O}$ modo como as palavras são usadas permite que possamos falar de objetos, mesmo que eles não existam (PB §36), cores e sons "mesmo quando eles não estejam presentes" (PB §32), pressupondo não os "elementos do complexo" (PB §28), mas sim o uso correto das palavras em seus diferentes espaços e das proposições como figurações de estados de coisas. Se alguém deseja representar um fato qualquer sem utilizar palavras, ainda assim precisa de uma intenção. Se alguém quer mostrar que 'João chegou em casa' poderá utilizar, por exemplo, uma caixinha de fósforos para representar a casa e um palito para representar João, colocando o palito dentro da caixa ${ }^{18}$. Este exemplo mostra de forma clara como a figuração acontece: uma forma de intencionalidade usa um fato (a relação entre o palito e a caixinha) como fi-

\footnotetext{
${ }^{17}$ Podemos encontrar os diferentes "espaços" gramaticais na divisão do texto das PB feita por Rhees da seguinte forma: os parágrafos $\S 3, \S 7, \S 8, \S 33, \S 36, \S 38$ dos capítulos I a III tratam de maneira geral desses espaços, enquanto a discussão sobre o "espaço das cores" se encontra em grande parte dos capítulos IV, VIII, IX e XXI. O capítulo V trata do tempo, o VI da dor e o VII do espaço visual. Os capítulos XX a XIX tratam da filosofia da matemática enquanto os capítulos finais (XX-XXII) voltam a tratar do espaço visual.

18 ENGELMANN, M. Wittgenstein's Philosophical Development: phenomenology, grammar, method and the anthropological view. p. 79.
} 
guração de outro (João e sua casa). No caso da figuração por meio da linguagem, uma proposição, como uma expressão de expectativa, que também é um fato, é utilizada como uma figuração de outro fato (no caso, aquele que realiza a expectativa) por uma forma de intencionalidade, fazendo uso das palavras dentro de contextos específicos. Terminada essa exposição, voltamos, portanto, para a relação entre intenção e métodos de verificação.

Na seção §31 o autor volta a falar da importância da intenção e a comparar a linguagem com uma sala de controle, com várias alavancas ou mecanismos. Esse ponto é importante, pois faz mais uma vez uma crítica à filosofia de Russell, ao dizer que tal mecanismo não pode ser conhecido "somente a partir dele mesmo" (PB §31b), ou seja, a partir de seus efeitos. Nessa metáfora não é possível conhecer o que é uma expectativa pelo efeito que um evento produziu em alguém, mas sim a partir do ‘propósito' para o qual a mesma foi construída. Dessa forma, de maneira semelhante à expectativa, uma máquina já tem uma função definida, assim como a expectativa é definida pelo evento que a realiza, ou seja, ela é sempre direcionada, expectativa 'de algo'. A máquina em questão foi construída para algo, ou seja, com uma função específica. E da mesma forma a expectativa é sempre 'de algo' específico, antes mesmo de sua realização. Nesse ponto encontramos o ponto de convergência entre a intenção e as relações internas explicitadas anteriormente: o que mostra que expectativa e evento estão em relação interna é justamente o seu direcionamento, o 'ser expectativa de algo', e assim ser definida pelo evento, sendo verificada pelo acontecimento do mesmo, e nada mais. Tal direcionamento é encontrado também na seção $§ 35$, aonde de lê sobre a necessidade de se 'dirigir a atenção', ou seja, de se 'apontar na direção de algo', de se pressupor um determinado direcionamento que vai da expectativa para um ponto específico da realidade. Uma expectativa pode ser descrita e verificada quando se é possível descrever o evento em questão, ou seja, na possibilidade de comparar a descrição do evento com a descrição da expectativa (PB §35). Descrever o evento significa dar uma descrição da expectativa, e isso só é possível 'olhando para o mundo' segundo um método. A verificação aqui constitui a possibilidade de se aplicar um padrão, uma escala (Maßstab), ou seja, um critério ao evento esperado. Se alguém espera que alguém tenha $1,80 \mathrm{~m}$ de altura, utilizará uma 
fita métrica para verificar essa expectativa, por exemplo, e não uma balança. Mais uma vez aqui notamos a importância de uma intenção no modo como nos dirigimos ao evento para verificá-lo: expectativa e evento devem estar no mesmo espaço de possibilidades gramaticais, a saber, no "espaço da altura” (PB §33). É importante ressaltar que aqui a fita métrica ou a régua fazem parte da linguagem ${ }^{19}$, assim como a balança ou uma tabela de cores, com a qual podemos comparar determinada mancha, ainda que seja um tipo de linguagem diferente da proposição. Não há mais uma linguagem ideal na filosofia das PB, mas diferentes linguagens, ou seja, "diferentes classes de linguagem" (PB §1) funcionando ao mesmo tempo, com possibilidades de combinação e de diferentes formas de figuração (PB §24).

A intenção aqui permanece no modo de se usar sinais sonoros ou escritos para se expressar expectativas e verificá-las por meio de um método, no qual também está implícito um elemento intencional. Conforme Wittgenstein afirma no $\S 30$, podemos ter desejos e expectativas por meio de signos, de forma que estes sinais também sejam usados de modo intencional. Portanto a intenção se manifesta nas $\mathrm{PB}$, tanto no modo de se usar 'sinais escritos' em uma folha de papel (que podem ser entendidos como fatos) para se expressar expectativas ou descrever eventos (outros fatos), quanto na maneira como se usa um método de verificação específico para se comparar a expectativa com o evento.

O sentido de uma expressão de expectativa, de um desejo ou de uma proposição descritiva está intimamente relacionado ao modo como nos dirigimos ao mundo para verificá-las. Na seção $§ 43$ o autor, mais uma vez, diz que entender o sentido de uma proposição significa 'como' a sua verdade ou falsidade é decidida, ou seja, como ela pode ser verificada. Os espaços de cor, de 'claro e escuro', 'pesado e leve', 'peso' e 'comprimento', por exemplo, aqui citados, fazem parte do simbolismo (PB §45), ou seja, fazem parte da linguagem. É o modo como nos direcionamos à realidade que permite saber a verdade ou falsidade de uma expectativa, desejo, etc. O seu sentido é a possibilidade de a expectativa ser verificada de tal e tal maneira. É ao se comparar uma expectativa com um evento por um determinado "padrão"

19 ENGELMANN, Mauro. Figuração, 'espaços e Intencionalidade': adaptando o Tractatus (PB II, III, IV) in CARVALHO. M. et al. Fenomenologia, Análise e Gramática: comentário às Observações Filosóficas de Wittgenstein. p. 80. 
(PB §44) que aplicamos o método de verificação, medindo com uma fita métrica, pesando com uma balança, comparando duas coisas lado a lado, procurando aproximar o ouvido para diferenciar sons, etc. Isso é especialmente evidente quando procuramos algum ponto no espaço visual. Se alguém afirma que uma estante de um metro e meio está a dois metros de distância, todas as outras possibilidades descritivas são excluídas. Todos os estados de coisas que não correspondem a essa descrição são, portanto, falsos. Esse é justamente um dos pontos que levam o autor a mudar a sua visão a respeito das proposições elementares, quando tratam de um conteúdo fenomenológico (ainda que a discussão permaneça no terreno gramatical e o sentido não deva depender de qualquer observação). Se um ponto no espaço visual é verde, ele não poderá ser vermelho, de forma que uma proposição que descreve o ponto verde exclui necessariamente a possibilidade de o mesmo ponto ser vermelho. E como estas são cores que não se combinam e são adequadamente representadas em oposição no octaedro das cores (PB §1 e §221), não há possibilidade de passar de uma para a outra. Dessa forma, o padrão a ser aplicado deve levar isso em consideração. Tal padrão deve corresponder às características do espaço no qual a expectativa acontece. Pois também não seria possível verificar uma cor no campo visual por meio do sentido do tato (PB §43). Não seria possível procurar de modo errado, neste sentido, pois a intenção já está implícita no próprio ato de procurar, ou seja, no próprio sentido de se procurar por alguma coisa. Portanto o próprio sentido da procura já exprime algo que se quer encontrar (PB §33), ou em outras palavras, o sentido da procura da expectativa, já expressa o que se pretende encontrar, ou esperar, ou desejar: o sentido de um não é diferente do sentido do outro. Como o próprio autor afirma no $\S 46$, o nome da cidade 'Londres' só tem significado se for possível localizá-la de alguma forma, dentro dos seus contextos específicos. É a intencionalidade implícita no uso da linguagem que encontrará a melhor forma de se chegar à Londres.

A partir de toda a análise empreendida neste trabalho é possível concluir que um elemento de intencionalidade se encontra presente no que o autor chamou de 'elemento de intenção' nas PB. Com o objetivo de apresentar o real funcionamento da linguagem, Wittgenstein se opõe, nessa obra, à teoria causal de expectativa e de linguagem de Russell, denunciando a sua de- 
pendência de uma relação externa por meio de um terceiro evento que nada teria a ver com a relação entre pensamento e fato. Contra essa visão, Wittgenstein apresenta a dependência da linguagem de um elemento de intenção, implícito no modo como se compara figuração e fato, por meio de um método de verificação. Tal método dialoga com a concepção de gramática desenvolvida nas $\mathrm{PB}$, na qual um tipo de contextualismo está presente nos diferentes espaços gramaticais (cor, altura, peso, etc), aos quais os usos das palavras estão sujeitos, e segundo os quais a verificação de uma expectativa pode ser empreendida. Para isso, nessa concepção de figuração mais ampla, objetos como réguas, balanças e tabelas de cores podem ser usados como partes da linguagem. Podemos perceber que, a partir da necessidade de uma forma de intencionalidade na relação entre linguagem e mundo, delineia-se um novo rumo para a filosofia de Wittgenstein. Por meio dela, o autor procura reparar problemas encontrados no TLP, ao mesmo tempo reparando os erros de Russell na sua descrição do funcionamento da linguagem. Nota-se ainda que Wittgenstein sustenta ideias anteriores, tais como de relações internas e expõe novas ideias com base em termos anteriores, tal como o método de projeção. As PB se constituem como um trabalho de transição, mas não se resumem a apenas isso, pois apresentam uma filosofia nova, sendo um trabalho rico, de novas ideias e novos caminhos, possuindo uma relevância fundamental para o percurso filosófico do autor e para o desenvolvimento da própria Filosofia da Linguagem enquanto corrente filosófica.

\section{Referências}

CARVALHO, Marcelo, CUTER, J. V. G., ENGELMANN, M. L., PRADO NETO, B. Fenomenologia, Análise e Gramática: comentário às Observações Filosóficas de Wittgenstein. Vol. 1. São Paulo: Mundaréu, 2017.

CUTER, J. V. G. Por que o Tractatus Necessita de um Sujeito Transcendental? in Revista Dois Pontos: subjetividade e linguagem. v. 3. Curitiba: Universidade Federal do Paraná, 2006.

ENGELMANN, Mauro Luiz. Wittgenstein's Philosophical Development: phenomenology, grammar, method and the anthropological view. New York: Palgrave Macmillan, 2013. (History of Analytic Philosophy). 
MÁCHA, Jakub. Wittgenstein on Internal and External Relations: tracing all the connections. London: Bloomsbury, 2016. (Blommsbury Research in Analytic Philosophy).

MELLO, Marcio R., Intencionalidade nas Observações Filosóficas de Wittgenstein: o elemento de intenção. 2015. 1f (Mestrado em Filosofia) - Universidade Federal de São Paulo, Escola de Filosofia, Letras e Ciências Humanas, Guarulhos, 2015. Orientação: Prof ${ }^{\circ}$ Dr. Marcelo Silva de Carvalho.

RUSSELL, Bertrand. The Analysis of Mind. New York: Dover, 2005.

WITTGENSTEIN, Ludwig. Observações Filosóficas. São Paulo: Loyola, 2005. Chicago Press, 1975.

Philosophical Remarks. Chicago: The University of . Philosophische Bemerkungen. Frankfurt a.M.: Suhrkamp Verlag, 2012. Werkausgabe Band 2. (Suhrkamp Taschenbuch Wissenschaft 502).

. Tractatus Logico-philosophicus. Trad. Luiz Henrique Lopes dos Santos. São Paulo: Edusp, 2017.

Tractatus Logico-philosophicus: Tractatus Logico-philosophicus, Tagebücher 1914-1916, Philosophische Untersuchungen. Werkausgabe Band 1. Frankfurt a.M.: Suhrkamp Verlag, 2014. (Suhrkamp Taschenbuch Wissenschaft 501). 
ANÁLISE DAS CONSIDERAÇÕES INTEMPESTIVAS A PARTIR DAS CARTAS DE NIETZSCHE: INDICATIVO DE UMA PERSPECTIVA ESTÉTICA E EDUCATIVA

\title{
Analysis of Untimely Meditations from Nietzsche's letters: indicative of an aesthetic and educational perspective
}

Enock Silva Peixoto ${ }^{1}$

\section{RESUMO}

Dentre os anos de 1873 e 1876 Nietzsche escreveu quatro livros que denominou como Considerações Intempestivas: David Strauss, confessor e escritor; Da utilidade e desvantagem da história para a vida; Schopenhauer como educador e Wagner em Bayreuth. Neles, o filósofo estabelece uma crítica a favor de uma cultura elevada, cujos clássicos da Grécia e Roma Antigas e da própria Alemanha são os meios educativos apresentados como contraponto. A adversária é a concepção gregária de cultura, vigenteno século XIX, que, conforme Nietzsche, tinha os interesses utilitários do Estado como forma principal de organização da vida. Esse [o Estado] sugava todas as forças criativas, como da educação juvenil, dos interesses científicos, reduzindo todos ao jugo dos negócios. Foi o período em que a Alemanha venceu a guerra franco-prussiana e buscava se estruturar politicamente, mas, Nietzsche percebe diversas armadilhas presentes neste processo, como o perigo da cultura se tornar serva da política. Essa preocupação aparece também nas suas correspondências, escritas dentre os anos de 1850 e 1888, nelas, também observamos o pensamento como "instrumentos de combate" contra a decadência social.

Palavras-chave: Arte. Intempestividade. Educação. Cultura.

\begin{abstract}
Between the years 1873 and 1876 Nietzsche wrote four books which He called Untimely Meditations: David Strauss, the confessor and thewriter; Onthe Uses and Disadvantages of History for Life; Schopenhauer as educator and Wagner in Bayreuth. In them, the philosophe restablishes a criticism in favor of a high culture, whose classics from Ancient Greece and Rome and Germanyit self are the educational means presented as a counter point. The adversaryis the gregarious conception of culture, in force in the 19 th century, which, according to Nietzsche, had the utilitarian interestsof the State as the main form of organizing life. This [the State] sucked up all creative

\footnotetext{
${ }^{1}$ Universidade do Estado do Rio de Janeiro e Universidade Federal do Rio de Janeiro.

E-mail: enock-peixoto@hotmail.com. ORCID: 0000-0003-4687-2018.
} 
forces, such as youth education, scientific interests, reducing everyone to the yoke of business. It was the period when Germany won the Franco-Prussian war and sought to structureit self politically, but, Nietzsche perceives several pitfalls present in this process, such as the danger of culture becoming a servant of politics. This concern also appears in their correspondence, written between the years 1850 and 1888, in them, we also see thought as "instruments of combat" against social decay.

Keywords: Art. Untimely. Education. Culture.

\section{As Considerações Intempestivas: combate a favor da cultura}

O nosso recorte de pesquisa, no momento, será apenas o período dentre os anos 1869 a 1874. Salientamos que fizemos traduções em português das citações das cartas, cuja principal fonte de pesquisa foi uma tradução para o espanhol das missivas nietzschianas. ${ }^{2}$ Nos deteremos a estas missivas que tratam de forma mais direta as correspondências que o filósofo abordou de forma mais intensa sobre as Considerações intempestivas. ${ }^{3}$ Refletiremos como estas obras figuraram como instrumentos de luta a favor de uma cultura elevada, não dominada pelos interesses institucionais e como, a partir delas, podemos pensar em uma formação intempestiva, impulsionada

\footnotetext{
${ }^{2}$ O presente texto é parte da tese doutoral com o título: As correspondências de Nietzsche e a educação em Assim falou Zaratustra: um processo de educação-estética na qual analisamos, tendo as cartas como principal fonte de pesquisa, como Nietzsche associou constantemente "escrita-vida-pensamento" na sua perspectiva filosófica. Limitaremos-nos a analisar as correspondências a seguir: NIETZSCHE, Friedrich. Correspondencia II: abril de 1869 dezembro de 1874.Traducción y notas a las cartas de José Manuel Romero Cuevas y Marco Parmeggiani Introducción y apéndices de Marco Parmeggiani. Editorial Trotta, Madrid, 2007. Elas fazem parte de uma tradução espanhola em seis volumes das correspondências do pensador alemão, publicadas pela editora Trota. É importante também destacar que seguiremos o modo como os tradutores numeram e datam as missivas nietzscheanas nessa tradução; para não sobrecarregar o texto, utilizaremos em alguns momentos apenas os números das cartas e em outros, a datação completa.

3 Salientamos que existem autores que traduzem este conjunto de textos como Considerações extemporâneas. Sobre o sentido dado ao termo, recomendamos o artigo de: (DENAT, 2010, p. 85-96); para a autora, extemporâneo tem o sentido de tomar distância do próprio tempo e dos seus valores. A interpretação de Tereza Calomeni também contribui para compreender o sentido deste termo, como estar fora do tempo e até mesmo ser contrário a ele, mesmo que nele presente: "Intempestividade precoce, desde os primeiros escritos, Nietzsche não é compreendido por seus contemporâneos que, em sua franca opinião, não são criadores ou legisladores, dado o hábito de pensar através da ótica dos valores já consagrados pela moral da metafísica e da religião cristã, dado o apreço que ainda nutrem pela verdade. A voz de Nietzsche destoa na modernidade ainda presa à valorização da educação como erudição, à necessidade de constituição da ciência como explicação da realidade, ao "excesso de sentido histórico" ou a um tipo de historiografia que, apelando sempre à memória e às ideias de evolução, progresso e finalidade e não ao esquecimento, tão favorável à felicidade humana, em nada favorece o respeito à vida e ao que, no tempo, se perfaz" (CALOMENI, 2011, sem paginação).
} 
para o futuro, confrontando os modos de vida dominantes; concepção que perpassa por uma educação intimamente associada à arte.

Na correspondência a Carl von Gersdorff de 5 de abril de 1873, (carta 301), há um relevante destaque: o anúncio sobre a Primeira consideração intempestiva. O propósito inicial de Nietzsche fora escrever treze textos deste tipo que, como veremos adiante, seriam como armas combativas contra a decadência da mesma:

No entanto, talvez um dia eu consiga fazê-lo, quando tiver realizado o que tenho agora em mãos, isto é, um escrito contra o famoso escritor David Strauss. Eu li agora sua Velha e nova fé e fiquei estupefato pela obtusidade e vulgaridade tanto do autor como do pensador.

Em agosto de 1873, foi publicada essa primeira obra com o título David Strauss, o confessor e o escritor; embora o filósofo tenha elaborado outras no mesmo período, As Intempestivas ganham destaque nas cartas e, por isso, abordaremos algumas das reflexões da fase em que estavam sendo gestadas, pois diversos temas revelados nelas fortalecem a nossa tese de que existe a constituição de uma educação pela arte na filosofia nietzschiana.

As reflexões presentes nas Intempestivas estiveram no contexto da luta pela cultura, em contestar uma sociedade que ele denominara como semibárbara, por não motivar modelos sui generis de vida. A cultura deveria motivar o impulso para provocar e manifestar a força mais expressiva em um povo, sem copiar outra cultura, como Nietzsche acusava ocorrer com a Alemanha em relação à França. Além disso, elevação cultural, de forma alguma, estava envolta em atrelar a formação dos jovens aos interesses utilitários do Estado, mas em constituir uma sociedade em que a cultura não figurasse como serva estatal. Para Safranski, comentando as três forças do existir que o historiador Jacob Burckhardt definiu como: o Estado, religião e cultura, acena que para Nietzsche a mais importante era a cultura: "Por ela tudo deve acontecer. Ela é o objetivo superior, e onde pensa ver uma subordinação da cultura aos objetivos do Estado ou da economia, ele fica indignado" (SAFRANSKI, 2001, p. 61). Burckhardt foi um dos personagens importantes para a construção da Segunda Consideração Intempestiva, a sua concepção de história está presente de forma clara na visão histórica de Ni- 
etzsche e na sua luta a favor da cultura. A história deveria existir para criar indivíduos que se tornam exceções e este é:

aquele sem o qual o mundo nos pareceria incompleto, porque determinadas grandes ações só podiam ser concretizadas por ele, em sua própria época e ambiente, sendo inconcebível sem ele. O grande homem está fundamentalmente ligado ao grande fluxo centraldas causas e efeitos. Há um provérbio que diz:"nenhum ser humano é indispensável", mas justamente os poucos que os são, são grandes homens (BURCKHARDT, 1961, p. 214-215).

Uma força extraordinária, não transcendente, é o que deveria marcar os grandes personagens históricos, a ponto de estes serem como "obras de arte", a saber, tão originais que não poderiam ser copiados, revividos, mas exatamente por isto, seriam um horizonte, um norte capazes de impulsionar novos criadores. O historiador classifica tais grandes homenscomo filósofos e eles são potencialmente os poetas, os artistas e os cientistas. São capazes de recriar o mundo, de inventar modos de vida, de desafiar a perenidade da história, mas essa potencialidade não se restringe a eles, pois eles devem: “ser incluídos na categoria de filósofos todos aqueles que veem a vida de maneira tão objetiva que parecem pairar acima dela, documentando essa sua Weltanschauung transcendente em observações formuladas sobre os mais diversos assuntos" (BURCKHARDT, 1961, p. 218).

Nietzsche contrasta o excesso de sentimento histórico presente em nossa cultura, com uma clara crítica à concepção hegeliana de história, para quem esta é a efetivação do Espírito Absoluto no mundo; tanto para Nietzsche, quanto para Burckhardt ela não tem sentido preciso, objetivo, não se trata de uma efetivação da Razão na história; a história não tem significado prévio. Neste caso, resta ao homem elaborar modos de existir, apesar da perenidade e inconstância dele. Conforme comenta Luiz Costa Lima, sobre a filosofia da história de Burckardt: "Em vez de ser isso ou aquilo, a História é a residência de um animal contraditório, capaz de atrocidades, de promover e de suportar dores incríveis e de criação" (LIMA, 2003, p. 14). Atrelar educação a uma aglomeração desordenada e indistinta dos comportamentos sem uma "unidade no estilo" seria um dano cultural

\footnotetext{
4 Na primeira Intempestiva, Nietzsche define cultura como "a unidade de estilo artístico em todas as manifestações de um povo" (NIETZSCHE, 1932, p. 6).
} 
pérfido. O filósofo questionava o predomínio de uma educação que anula o que é genuíno tanto em uma coletividade, como nos indivíduos, para ele quem promove a cultura de um povo "deve aspirar a promover esta unidade suprema e trabalhar conjuntamente na aniquilação deste modelo moderno de formação" (NIETZSCHE, 2003, p. 43). A formação de um estilo que o filósofo apregoava como tão fundamental na vida individual, era também uma exigência comum. A sociedade precisa ter identidade, feição própria, singularidade para ser forte; atingir esta meta, ao mesmo tempo particular e social era um dos esforços que o filósofo naquele período assumia como uma tarefa.

Junto com o seu trabalho intelectual, situações alegres e dolorosas o impulsionavam; a missiva 315 contém um comentário sobre o que Nietzsche denomina como "qualidade dos Nietzsche". Ele escreve àsua mãe Francisca, por ocasião do falecimento da tia Friederike Daechsel; após uma análise sobre o sentimento constante de solidão que a morte causa, observa:

[...] Eu gosto muito de pensar na tia Riekchen, [...] que até uma idade avançada mantinhauma natureza única e encontrou apoio em si mesma para depender o mínimo possível do exterior e da benevolência incerta dos homens: gosto disso, porque nisto encontro a qualidade da raça daqueles que se chamam Nietzsche, qualidade que também tenho. É por isso que a querida tia foi sempre afetuosamente disposta comigo, porque estávamos relacionados em uma coisa essencial, isto é, na essência dos Nietzsche. E assim eu honro a memória dela, desejando com todo meu coração, se chegar envelhecer, que eu não me separe de mim mesmo, isto é, do espírito de meus pais $[\ldots]$.

A tia e outros parentes falecidos serviram de exemplo para o filósofo. Foram pessoas que se esforçaram durante a vida para manter a autonomia, depender o menos possível do mundo externo e da benevolência humana, aventa isto. O filósofo sentia a postura propositiva da tia em relação a ele, possivelmente por perceber a sua vida austera, "que buscava apoio em si mesmo"algo que ela valorizava. Ele salienta a força dos Nietzsche. Notemos que a valorização de uma vida na qual a singularidade, a autonomia, a liberdade são enaltecidas, não fora um aprendizado apenas nas instituições escolares, com os filósofos, os artistas. Mas foi também, "dentro de casa"; ele teve exemplos consanguíneos de experiências próximas daquilo 
que denominava como exemplo de educação, a saber, estabelecer um peculiar trajeto existencial.

A Carl Fuchs em 30 setembro de 1873 (carta 317), Nietzsche alude ao seu problema de visão, pois as cartas estavam sendo escritas por outra pessoa. Mas o conteúdo essencial delamesma é a demonstração do seu domínio sobre teoria musical. O filósofo discorda do interlocutor sobre a interpretação da música: "Noite de julho".

[...] De fato, sobre "Noite de Julho" não estou totalmente de acordo, e minha perplexidade tem a ver exatamente com a sua parte central: o "adágio com sentimento". Se o compositor quer nos dar a impressão de que o cantor de noite de julho está recordando alguma felicidade interior, ele não precisa necessariamente expressá-lo com uma melodia que soa como uma lembrança, mas apenas lembrando, precisamente, melodias íntimas e alegres. O mesmo vale, creio eu, para a melodia de resignação na última página. Inclusive, estou inclinado a acreditar que a composição em seu conjunto, em vez de ter sido "sentida" antes, como deve ser com qualquer boa peça, só foi sentida "depois".

Salientemos a observação do final do fragmento de carta selecionado que é o aceno ao entendimento de que toda boa peça precisa ser antes sentida e só depois construída e executada. Essa visão suscita a interpretação de que uma composição harmoniosa nasce da vida, dos sentimentos e emoções bons ou ruins que a existência nos apresenta, ou seja, primeiro precisa ser vivida e depois pensada, o aspecto informal da composição se antepõe ao seu aspecto formal. Entendemos que somos autorizados a fazer esta observação considerando a relação de Nietzsche com as suas próprias composições. Ele sempre acena para algo vital que possibilitara o seu surgimento, além disso, nas obras publicadas, como em $O$ nascimento da tragédiahá clara alusão a esta valorização da vida sobre a formalidade da composição.Ao comentar em uma resenha à obra, Erwin Rohde, escrevendo como a tragédia nascera, para Nietzsche, no espírito da música, fortalece esta concepção:

Em uma luta aterradora, a música dá à luz o mito, uma imagem analógica das forças universais onipotentes. O conhecimento conceitual jamais possibilitará que se acompanhe a ação das forças por meio das quais a potência universal, que se encontra fora do tempo e do espaço, vem a se manifestar na obra do artista, tornando-se reconhecível primeiro na forma do tempo, e depois erigindo a partir 
da música a imagem analógica que se move simultaneamente no tempo e no espaço. Quem fosse capaz de entender esse processo teria resolvido o enigma do mundo (ROHDE, 2005, p. 37-38).

Esta interpretação, elogiada por Nietzsche e recusada pela revista à qual foi enviada, aponta paraa contiguidade entre vida e arte. Noção que a lógica seria incapaz de dar conta como do segredo inerente ao processo do real, que só pode ser manifesto, se tornando uma linguagem interpretável, pelo menos parcialmente, através da arte. Na continuidade da missiva em questão, além do aspecto técnico que ele aponta, demonstra claramente o seu descontentamento com a utilização mercadológica da arte, no caso específico, da música:

Mas neste trabalho precisamente, mais obrigatório que necessário, revela-se também um grande talento ilustrativo, e refiro-me sobretudo à primeira página. Muito mais autônoma e mais vívida, encontro a Viagem noturna, cuja introdução e parte central são realmente magistrais. A melodia principal que começa na página 4 , no entanto, não me parece muito boa, embora eu acredite que descubro aqui, como em geral ao longo da composição, uma orquestração encantadora. - Agora, a questão número dois: "Dr. Fuchs, o sintomático"! Durante o verão, tive tempo de refletir sobre os músicos escritores, e justo com vistas a um semanário dedicado à música. Um semanário desse tipo é dirigido, como sabemos, quase exclusivamente para leitores músicos; e os interesses destes, que determinam a natureza da revista, não são, graças a Deus, literários quase em vão, e ainda mais, na medida em que pedem um semanário, são exclusivamente interesses comerciais. Um procura por uma posição, outro procura alguém para tocar sua música: este, por sorte, ainda é o sentido ingênuode uma revista de música desse tipo.

Nietzsche estava ciente que a música poderia ser utilizada como mercadoria, mas ele acena a palavra exclusivamente, certamente atentando para o perigo de a arte perder a sua característica principal e se tornar um negócio como outro. Ela, conforme comenta Guervós, deveria existir como um meio de educarmanifesto em sua capacidade de estar plenamente em si mesma: "aprender a pensar e a pensar e ouvir o silêncio musical deixando que as coisas sejam por si mesmas em seu silêncio" (GUERVÓS, 2004, p. 457). Ao invés de proporcionar a função de educar o ser humano para a singularidade viria a se tornar algo que massifica, iguala, nivela os comportamentos. Como é a tendência da maioria dos produtos que tem como objetivo principal a negociação, trata-se do perigo da música perder a sua "essência". Algo que ocorreu posteriormente em grande escala. A carta 324 a Carl von 
Gersdorff merece destaque porque Nietzsche revela nela a publicação da segunda edição de $O$ nascimento da tragédia que seria lançada em janeiro daquele ano. Também anuncia que a Primeira intempestiva chegara ao público, acena também para a segunda edição desta e manifesta que a segunda já tinha o manuscrito pedido pelo editor Fritzsch. Além desses dados editoriais, a carta mostra que o incômodo com as obras do filósofo ganhara intensidade.

Os cadernos verdes do Grenzboten publicaram recentemente um non plus ultra com o título "Sr. Friedrich Nietzsche e a cultura alemã". Apela a todos os poderes, polícia, tribunais, colegas, afirmase expressamente que em todas as universidades alemãs a minha reputação é péssima, e é desejável que mais cedo ou mais tarde ocorra o mesmo em Basileia. É relatado que, graças à habilidade de Ritschl e à estupidez do povo de Basileia, como estudante eu teria me tornado um professor numerário, etc. Insultou Basileia, chamando-a de "universidade provincial", eu próprio fui denunciado como inimigo do Estado alemão, associado à Internacional etc. Em suma, um documento altamente recomendado por sua comicidade. Que pena que eu não posso enviar para você. Fritzsch também é atacado: é considerado um escândalo que um editor alemão me tenha aceitado. Portanto, queridíssimo amigo, nossa primeira Intempestiva "encontrou o favor do público" [...].

O filósofo alemão alude à sua posição quando passava por muitas críticas, assim como comenta a situaçãodo amigo, que não fora aceito como professor universitário com a justificativa de ser muito jovem. Diante de tantas barreiras, apresenta-se o desespero ou a esperança como alternativas, ele assume a última como escolha.A correspondência 342 a Carl Fuchs mostra que as circunstâncias encaminham Nietzsche ao distanciamento da função acadêmica. Além de demonstrar que queria uma vida mais livre, como destacamos, mesmo antes de começar a trabalhar na atividade formal docente, ele indicava os limites dessa função, entretanto, parece possível considerar que o filósofo fora precocemente empurrado para o ostracismo acadêmico:

[...] A verdadeira solidão reside em uma grande obra. O ensino ou vida acadêmica - eles não representam nada, ou pouco mais que o marco externo de nossa existência. Refugiar-se nela é algo que Overbeck e eu - já não entendemos bem, já que muitas vezes temos pensado o contrário, na fuga até a completa liberdade de qualquer obrigação para continuar a viver com absoluta liberdade de pensamento em um rincão qualquer da terra, ainda que seja em condições modestíssimas. E por essa razão, dificilmente podemos 
ser bons conselheiros para você. Para Basileia, para o resto, ninguém poderia garantir nada para você. Nós não temos nenhuma cátedra de música, e nós não poderemos obtê-la porque nesta cidade pouco musical você dificilmente poderia encontrar mais do que dois estudantes. As cátedras pagas da filosofia são completamente inacessíveis para um seguidor de Schopenhauer, como nos força a concluir alguma experiência muito significativa: em geral, há pouca inclinação em favorecer de alguma forma esta "tendência" [...].

Mais uma vez aparece a queixa por Basileia não ser um lugar musical e a dificuldade de seguidores de Schopenhauer conseguirem espaço de trabalho. A arte e a filosofia moviam os interesses de Nietzsche. Além disso, a possibilidade de viver com "absoluta liberdade de pensamento", que, possivelmente, poderia ajudar a emergir uma grande obra advinda de uma verdadeira solidão. O filósofo não pretendia se refugiar na vida acadêmica e esta afirmação vem após acentuar o desejo de liberdade, ficando claro que não eram apenas as dificuldades externas que o distanciaram da função docente e nem uma preguiça ou desdém pelo trabalho; mas o anseio por um modelo de vida sui generis.

É importante lembrar que a saúde de Nietzsche era frágil, sendo os momentos de estabilidade a exceção; nas cartas deste período ele relatara dados sobre a sua debilidade em vários momentos, como a constante dor de cabeça; mas a carta 354, à sua mãe, mostra que naquele período, especificamente, estava bem. O seu sofrimento era outro, aquele oriundo das dificuldades que passava na convivência social; admite que sofria demasiadamente e acrescenta: "[....] e posso ser feliz se estiver fisicamente doente, porque então eu penso que poderia ser ajudado: algo que agora, sem ter a doença como um pretexto, eu considero impossível de qualquer maneira." O itinerárioimediato da carta revela o que Nietzsche considerava o seu caminho: "[...] cada um deve seguir o seu próprio caminho: eu desafogo jogando minhas imprecações no papel impresso, e agora eu quero retomar o trabalho para o número 3 de minhas Intempestivas [...]."

Pode-se considerar que o filósofo está utilizando o termo caminho de forma genérica, ou seja, todo ser humano deve seguir as suas perspectivas, sem elas terem ressonância necessária em sua forma de viver, mas ele tinha um decurso claro: desafogava com o trabalho da escrita e todas as atividades que a envolvem: leitura, pesquisa... Atuar na elaboração de seus li- 
vros, este era o caminho, tinha um cunho particular, o senso de que escrever funcionava como uma tarefa, mas certamente, tinha também a intenção de repensar o modo de vida dominante na cultura ocidental.

\section{A luta pela cultural}

Diante de muitas informações ruins, Nietzsche recebera a boa notícia de que o professor Plüss pronunciara em Pforta uma conferência sobre $O$ nascimento da tragédia e sobre a Primeira intempestiva, acontecimento que o entusiasmoue foi narrado na carta 356 a Carl von Gersdorff de 1 de abril de 1874 e em outras seguintes. Na mesma, o filósofo contesta o modo como o amigo compreende a sua capacidade criativa:

[...] Eu realmente acredito que um dia eu vou te desapontar um pouco, e eu quero começar a fazê-lo imediatamente, confessando que, pelo que me conheço, eu não mereço em absoluto os seus elogios. Se você soubesse que opinião eu tenho no fundo de mim mesmo como ser criativo, com quanto abatimento e melancolia eu penso sobre tudo isso! Não procuro nada mais do que um pouco de liberdade, um pouco do ar autêntico da vida, e eu me oponho e me revolto contra todas as inumeráveis escravidões que me afogam. Mas não se pode falar em absoluto de uma autêntica criação, embora ainda seja tão escravizado, tão pouco livre do sofrimento e do sentimento opressivo de ser aprisionado em si mesmo. Eu vou conseguir? Dúvidas sobre dúvidas. O objetivo está demasiado longe, e quando finalmente o alcançamos, quase sempre esgotamos nossas forças na longa busca e luta: a pessoa chega à liberdade e se esgota, como uma mosca fugaz à noite. Isso me assusta muito. É uma infelicidade chegar tão cedo a tal consciência da luta em si!

Possivelmente, Gersdorff elogiara a sua capacidade de gozar de um "autêntico criar", mas, sustenta Nietzsche, ele buscava apenas um pouco de liberdade, diante de todas as escravidões que a vida oferecia. É possível que aquele sofrer não estivesse associado somente às suas dificuldades, mas também à própria compreensão da vida como dor, assim como um schopenhauereano interpretaria. O buscar e lutar frustra porque quando se adquire a liberdade, as forças já estão comprometidas. Alcançar a consciência dessa luta é uma desgraça. Embora Nietzsche conteste o seu ato criador e se considere frágil diante da avassaladora verdade de que a realidade é medonha, ele fora um criador e colocara exatamente no ato criativo a possibilidade de superação do sofrimento. 
Nietzsche escreve a carta 360 a Carl Fuchs em 28 de abril de 1874 que é valiosa para a hipótese em análise; nela indica certos caminhos que trilhava para a constituição de si mesmo e não há como negar que o seu "instrumento de combate" era a luta pela cultura elevada do seu povo. Ao escrever auma revista que Wagner tentara fundar sustenta: “[...] Mais tarde, depois, daqui a alguns anos, pensaremos em fundar uma arena pública para o nosso tipo de 'luta cultural' (realmente uma maldita expressão) - mais tarde, quando tivermos alguma assinatura a mais e não mais sejamos tão terrivelmente poucos quanto agora." A luta cultural está associada ao conhecimento. A luta contra a mediocridade do momento presente e por uma convivência social que supera a postura gregária dos comportamentos dando ênfase à singularidade. Nietzsche apresenta as suas armas para o embate naquele momento:

Até lá, cada um de nós tem que lutar sozinho com todas as suas forças: com as minhas treze Intempestivas, que estou publicando uma após a outra, eu forjei uma boa arma, com a qual golpeio a cabeça das pessoas até que saia algo. Eu gostaria que você fizesse o mesmo e se liberasse por este meio de todo o negativo, controverso e carregado de ódio que está em sua natureza, para então encontrar a paz e não mais ter nada que possa "induzi-lo a se contradizer". Conto com isso e me consolo pensando no tempo em que todo o combater, gemer e gritar será liquidado; mas, enquanto isso, devemos continuar "combatendo vigorosamente", como dissera algum velho marquês de Brandenburgo na época da Reforma.

O filósofo pretendia escrever treze intempestivas que na realidade foram quatro. Eram investidas virulentas, não para atingir como lanças ou bombas os corpos alheios e eliminá-los ou torná-los amedrontados, e por isso, submissos, mas elas deveriam golpear as inteligências, as cabeças, até que saísse algo. Trata-se de uma arma que levaria à reflexão, ao questionamento, ao pensamento, à elevação do senso comum e crítica ao momento vigente e a uma experiência civilizatória decadente. A continuidade da carta acentua o tom combativo pelo qual ele, diferente de carta anterior na qual admite não ser livre, não ser criador, deseja encontrar um caminho, ou, pelo menos, sentir por intermédio de onde poderia exercer certo grau dessa liberalidade: 
Porque no fundo todos sofremos intensamente e só suportamos a dor precisamente no combate mais assíduo, espada na mão. E como não queremos nada para nós mesmos, podemos nos lançar na luta mais sangrenta com uma consciência calma e serena, gritando uns aosoutros: "Só o soldado é um homem livre" [...] ele quer permanecer sendo ou se tornar um homem livre, não tem outra escolha: deve continuar "avançando e combatendo vigorosamente". E assim, que continue bem e seja valente, como companheiro de armas, na guerra e na vitória [...].

Nietzsche utiliza a linguagem militar para expressar a busca por uma cultura elevada como instrumentode guerra, mas quem são os adversários? Trata-se da falsa cultura, da falta de autodeterminação, na inação e ausência de constituição de si mesmo, de construção do próprio caráter. A coragem de dizer não a um mundo que oprime, que regula e obriga a oferecer a própria força favorecendo algo que não somose nem é do nosso interesse. Neste processo de luta, ele continua o seu labor. Nietzsche escreveu a Carl von Gersdorff conforme atesta a missiva 361 de 8 de maio de 1874 que já concluíra a Terceira intempestivae o trabalho de publicação em breve começaria. O título provisório fora "Schopenhauer entre os alemães", o definitivo trata de Schopenhauer como educador. Apresenta depois a elaboração de outro trabalho o "hino à amizade", considera como a sua melhor obra musical até o momento. A correspondência 362, para Emma Guerrieri-Gonzaga de10 de maio de 1874 está entre aquelas que tornam inequívoca a preocupação de Nietzsche com a educação. Essa é uma das mais sérias e relevantes tarefas da humanidade, por isso ele destaca:

Parece-me que você considera que uma transformação profunda da educação dos povos é a coisa mais importante do mundo - e, claro, você não estará esperando minha aprovação! Eu também não conheço um objetivo maior para mim mesmo do que tornar-me um dia "educador" em sentido grande: só que estou longe desse objetivo. Enquanto isso tenho que tirar tudo o que há de controvérsia, negação, ódio, tormento; e parece que todos nós temos que fazer isso para nos libertar: antes, temos que fazer toda a soma terrível de tudo o que evitamos, tememos e odiamos, mas, em seguida, uma vez que tenhamos concluído esta operação, não devemos dar nenhum olhar para trás, em direção à negatividade e esterilidade! Devemos nos limitar a plantar, construir e criar! É verdade que isso significaria "educar a si mesmo"! Mas quem o consegue bem e com continuidade! E, no entanto, é necessário, e não há outro modo de ajudar-se [...]. 
Nietzsche coloca lado a lado os verbos desejar e esperar. Mas isto sugere que tanto o desejo quanto a espera não estão isentos de ação e de responsabilidade. Na carta da amiga, ela salienta a transformação da educação como a tarefa mais elevada; o autor das Intempestivas orienta para a educação de si mesmo. Esta é, para o filósofo, o papel fundamental do ato de educar. A meta mais alta para Nietzsche era se tornar educador, mas salienta, em sentido amplo. Para entendermos este sentido amplo, basta que observemos as críticas de Nietzsche aos estabelecimentos de ensino de sua época e aqueles que ele considerava como mestres: os gregos arcaicos, Wagner, Schopenhauer, logo, o modelo de educador que ele visava ultrapassava o mestre escolar, embora este também pudesse exercer este papel. Ele se considera distante dessa meta e indica que sacar de si o ódio, a polêmica, a negação o tormento, seria o percurso necessário para ser livre, a meta deveria ser "plantar, construir e criar" o que significa "educar a si mesmo", o único modo de ajudar-se. Vejamos: a carta começou com um louvor ao esperar e desejar, que associamos à ação, à busca e o educar a si mesmo que o filósofo elabora parece estar neste esforço de estabelecer um ambiente de positividade; é possível que as experiências vividas naquele momento tenham gerado essas reflexões.

Ele devia estar envolto em sentimentos bastante negativos contra amigos, desafetos, a sua nação, a universidade, as várias circunstâncias que atingiam negativamente a sua vida. Esaber ultrapassar isto, conseguir viver em harmonia consigo, apesar das situações externas totalmente adversas era um desafio. A tarefa de educar a si mesmo se tornara uma necessidade vital. Oárduo e indispensável valorem saber colocar tanto o negativo como o positivo na balança da existência e vivê-los com harmonia foi uma exigência incessante.

A carta 364 a Erwin Rohde de aproximadamente 14 de maio de 1874 começaenfatizando os antídotos para a melancolia que o interlocutor antes citado the propusera. Os amigos estavam preocupados com Nietzsche, por este demonstrar certa soturnidade em suas missivas; ele admite este sentimento: 
algumas vezes me deixo levar por lamentos terríveis e estou sempre ciente de uma terrível melancolia para o meu destino e apesar de ser muito calmo; mas como não há nada que possa ser mudado, eu levo as coisas alegremente, procuro os elementos que universalizam minha miséria e recuso qualquer personalismo.

Mas o filósofo mantém de pé os seus projetos:

Para o resto, continuo fervorosamente fazendo projetos para me tornar completamente autônomo, e tendo abandonado todo relacionamento oficial com o Estado e a universidade, retirar-me para uma vida privada sem vergonha de ser individualista, miserável e simples, como queres, mas digna. Por enquanto, escolhi Rothenburg Del Tauber como uma fortaleza pessoal e solitária; no verão eu irei visitá-la. Ali pelo menos tudo segue a velha maneira alemã, odeio cidades feitas de elementos mistos, sem caráter, que não são mais algo inteiro. Além disso, a vida não deve ser cara. Espero que seja um lugar onde se possa ainda pensar a fundo as próprias ideias, fazer projetos por décadas e depois realizá-los [...].

O projeto de deixar a profissão docente e viver uma vida mais reclusa e livre ganhava corpo; indica Rothenburg Del Tauber como possível morada e acena para um aspecto importante, a falta de unidade no estilo das cidades alemãs, que segundo ele, não tinham "algo inteiro" devido aos seus aspectos demasiadamente híbridos. Um lugar, no qual se pudessem fazer projetos duradouros, era essencial. Para Nietzsche, o ambiente precisava ter caráter, que pode significar, a cidade precisaria ter uma dimensão estética que favorecesse a criação; o ambiente surge na reflexão de Nietzsche como aspecto fulcral na constituição de ideias e criações. Na carta 365 a Richard Wagner em 20 de maio de 1874, Nietzsche, já em um clima de tensão que se estabeleceu entre ambos, celebra a vida do mestre e faz uma associação direta entre ambiente-espaço-tempo e a criatividade, uma vez mais:

Muito venerado mestre: [...] faz cinco anos desde o sábado de pentecostes quando estive pela primeira vez diante de você em Tribschen. É o que é chamado de um lustro. E assim, nesta ocasião, quero usar seu aniversário para inventar uma nova maneira de contar o tempo, em lustro; os romanos os associavam a grandes sacrifícios de purificação e os celebravam como um verdadeiro festival de primavera. E assim devo celebrar também, como uma verdadeira festa de purificação e da juventude; porque para mim desde aquele maio de cinco anos atrás é como se eu realmente tivesse me tornado mais jovem e mais livre. Para o resto, as pessoas dizem que quanto mais anos se passam, melhor eu fico, pareço mais saudável e mais sereno e, em geral, pareço mais jovem. É uma sorte incomparável para quem anda cambaleando e tropeçando através de trilhas escuras e desconhecidas, encontrar alguém para conduzir lentamente em direção à luz, como você fez comigo; e por essa razão só tenho queestimá-lo como a um pai. 
O encontro com Wagner e o ambiente de Tribschen se tornou um novo nascimento; um nascimento para uma educação pela arte que trouxe luz para a sua vida. Foi um encontro que o rejuvenesceu fisicamente, e chega simbolicamente a remeter a uma contagem mais lenta do tempo. O filósofo lembra a celebração em quinquênio dos romanos, uma festa que comemorava a primavera, ou seja, tinha como pano de fundo a transformação da natureza relacionada às mutações do real. Mas o filósofo se sentia revitalizado, e externamente, era assim percebido. Ele que, cambaleava, possivelmente uma alusão à sua vida errante enquanto pensador, mas certamente, quanto às suas limitações físicas e visuais também. $\mathrm{O}$ encontro com a arte wagneriana figurou como um norte, uma luz. Eis que a "escola de arte" do músico, moldou, deu um ritmo e horizonte de vida, foi fonte de formação humana.

Malwida von Meysenbug em 25 de outubro de 1874 recebe uma missiva do filósofo (carta 398),onde testemunha que a vida de Nietzsche, embora não seja possível se falar em um alter ego, estava presente em seus textos, se referindo à Terceira intempestiva afirma: "O conteúdo deste último escrito lhe permitirá intuir várias coisas sobre as experiências que vivi durante este período. Apesar de que durante este ano minha situação foi às vezes muito pior e mais preocupante do que o que se pode ler neste livro." O filósofo ao mesmo tempo em que admiteque suas experiências mais singulares vividas naquele período ressoavam no livro, destaca certo distanciamento. A obra não era uma biografia, uma descrição dos seus próprios sentimentos, pois visava gerar informação, conhecimento, reflexão, algo próprio das obras filosóficas, entretanto, estava unida às vivências do seu autor, mesmo assim, ela não era capaz de mostrar a situação mais intensa que ele vivia. Como relatou em várias cartas nesse período, o filósofo indicava viver um momento sombrio:

Mas de qualquer modo as coisas seguem, seguem adiante, só há uma coisa que me falta muito, e é o aspecto solar da vida; se não fosse por isso eu teria que realmente dizer que não posso estar melhor do que estou. Pois é uma verdadeira sorte proceder no mesmo ritmo da própria tarefa - e agora terminei a três, das treze Considerações, e a quarta já está em minha mente [...]. Não pretendo muito sobre a vida, nem nada de extremo. Por outro lado, nos próximos anos, todos saberemos algo para que gerações passadas e futuras 
possam nos invejar. Eu também tive o dom, completamente imerecido, de magníficos amigos. Agora, falando em confiança, também desejo uma boa esposa, após a qual considerarei os desejos da minha vida satisfeitos. - Todo o resto depende de mim [...].

Ele tratava como tarefa os seus escritos, sua produção de pensamento, o analisar a cultura e oferecer certa perspectiva para ela. Nietzsche, como ocorre em várias cartas, destaca a intenção de se casar como algo que complementaria os seus desejos. Foram vários projetos de matrimônio que nunca se realizaram. Observemos nesta situação, uma das buscas de um aspecto solar como determinante para tornar a sua existência mais vibrante. Ele tivera a sorte de conseguir, naquele momento, adequar vida e tarefa. Mas, ainda havia certa dualidade no pensamento de Nietzsche, no entanto, mais tarde se tornará afirmativo e sustentará que o solar é primordial, mas o sombrio também o é. Trata-se do Nietzsche que vive a "metafísica de artista", ao mesmo tempo vai passando por transmutações que o levarão à sustentação irrestrita de uma vida movida pela dimensão estética e educativa; ou seja, que mesmo na luz, como na sombra busca forças para criar a si mesmo.

Eram as treze intempestivas que o moviam e eraanunciada na mesma missiva supracitada, o surgimento da quarta delas. Nietzsche trabalhou em torno deste quarto livro cujo título seria: "Nós filólogos"; mas o projeto não foi terminado, tendo se tornado a Quarta intempestiva, o livro Richard Wagner em Bayreuth de 1876. A correspondência a Carl von Gersdorff em 21 de julho de 1876 Nietzsche indica que Wagner legitimou o seu livro e se mostrou admirado como o amigo o conhecia tão profundamente. Considerou como um livro extraordinário. O teatro de Bayreuth era algo que tinha

\footnotetext{
5 Vários comentadores da filosofia de Nietzsche entendem que ela passa pela seguinte periodização: Metafísica de artista: O nascimento da tragédia e os textos preparatórios até as Considerações intempestivas e os Fragmentos póstumos do período, entre (1872-1877); trata-se do período de juventude, quando Nietzsche esteve influenciado além de outros pensadores, literatos e artistas, pela filosofia de Schopenhauer e pela música de Wagner. O período intermediário estaria entre Humano, demasiado humano e A gaia ciência (18781882), fase crítica de Nietzsche, à arte, a metafísica, ao conhecimento, aos artistas e finalmente, o período da maturidade, ocorrido a partir Assim falou Zaratustra até a última obra publicada Ecce Homo (1883-1888), neste momento, o filósofo teria elaborado os seus conceitos e concepções mais originais: como a de morte de Deus, niilismo, amor fati, superhomem, vontade de potência, eterno retorno e transvaloração de todos os valores. Sobre este tema da periodização da filosofia de Nietzsche, sugerimos a leitura do artigo do professor José Nicolau Julião: O Assim falou Zaratustra como obra capital de Nietzsche, em Leituras de Zaratustra. DIAS, R, VANDERLEI, S, BARROS, T. et.al. (Org.). Rio de Janeiro: Mauad X: FAPERJ, 2011, além das perspectivas de autores que defendem a divisão acima reunida, o comentador destaca outras visões importantes como Nehamas e Heidegger que partem de outras perspectivas.
} 
uma conotação não apenas artística, mas educativa e política também. Nietzsche acreditou que ele revolucionaria a arte, pois figurava como um modo de reviver a dimensão trágica da vida dos gregos arcaicos. $\mathrm{O}$ expectador, assim como na dramaturgia grega, era participante ativo da peça, se envolvia com ela e, desse modo, aquele teatro poderia ser um foco de transformação e produção de uma cultura elevada.Nietzsche considerou que se tratava não de uma nova arte, aquele ambiente de Bayreuth, mas, tratavase da arte mesma (Cf. NIETZSCHE, 2009). Foi neste contexto que o embate através das Intempestivasse mostrou como artilharia utilizada para enfrentar uma sociedade decadente visando o emergir de uma cultura vigorosa, criativa, inovadora.

Vimos que as cartas, no período da escrita e publicação das Intempestivas tratam de diversos eventos ocorridos na vida de Nietzsche: o seu contato com a arte, sobretudo a musical; o embate com função docente; a preocupação com o estilo na escrita; dentre outros aspectos. Elas revelam uma concepção estética e educativa, mas, não está atrelada, somente, aos parâmetros da formação institucionalizada, trata de algo que a extrapola, busca a constituição de um modo específico e singular de se colocar na existência. Um particular processo educativo de Nietzsche contribuiu para ele avaliar a formação coletiva e a imperiosidade de se pensar para além de um tempo desgastado e precário; por isso, a necessidade de uma postura intempestiva, voltada para o porvir, capaz de dar forma artística à existência, quando impulsiona à criação e a questionar o presente não apenas como contestação, mas provocando a invenção de novos mundos possíveis.

\section{Referências}

BURCKHARDT, Jacob. Reflexões sobre a história. Tradução de Leo Gilson Ribeiro, Rio de Janeiro: Zahar Editores, 1961.

.Cartas. Seleção e edição de Alexandre Dru. Tradução de Renato Rezende, Rio de Janeiro: Topbooks, 2003.

CALOMENI, Tereza Cristina Barreto. Intempestividade e Trágico em Nietzsche. Revista: O Percevejo. Programa de pós em Artes cênicas - UNIRIO. Volume 03 - Número 02-agosto-dezembro, 2011. 
DENAT, Céline. A filosofia e o valor da história em Nietzsche. Uma apresentação das Considerações Extemporâneas. Cadernos Nietzsche, n. 26, p. 85- 96, 2010

GUERVÓS, L. E. de Santiago. Arte y Poder. Aproximación a la estética de Nietzsche. Madrid: Trotta, 2004.

HEGEL, Georg Wilhelm Friedrich. Fenomenologia do Espírito. Trad. de Paulo Meneses e Karl-Heinz Efken. Petrópolis: Ed. Vozes, 1992.

JANZ, Paul Curt. Friedrich Nietzsche. 4 vols. Trad. Jacobo Muñoz. Madrid: Alianza, 1987.

LIMA, Luiz Costa. Alguém para ser conhecido: Jacob Burckhardt. In: BURCKHARDT, Jacob. Cartas. Seleção e edição de Alexandre Dru. Tradução de Renato Rezende, Rio de Janeiro: Topbooks, 2003.

MACHADO, Roberto. Nietzsche e a polêmica sobre $O$ nascimento da tragédia / textos de Rohde, Wagner e Wilamowitz-Mollendorff; Introdução e organização Roberto Machado; tradução do alemão e notas de Pedro Sussekind. Rio de Janeiro: Jorge Zahar Editor, 1995.

NIETZSCHE, Friedrich. David Strauss: El confesional y el escritor. In: ConsideracionesIntempestivas. Tradução E. Ovejero e F. González.Madri: Aguilar, 1932.

. DigitaleKritischeGesamtausgabe von NietzschesWerken und Briefen.Edição organizada por Paolo D'Iorio, baseada na edição crítica de G. Colli e M. Montinari e publicada pela Nietzsche Source. Edição eletrônica. Acesso em 01/04/2020.

.O nascimento da tragédia ou helenismo e pessimismo. Trad. J.

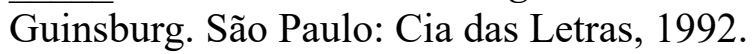

.Considerações extemporâneas. In: Obras incompletas. Coleção: Os Pensadores: seleção de textos de Gérard Lebrun. Tradução e notas de Rubens Rodrigues Torres Filho. São Paulo: Editora Nova Cultural, 1999.

.Sobre os nossos estabelecimentos de ensino. Escritos sobre educação. Tradução, apresentação e notas de Noéli Correia Sobrinho. Rio de Janeiro: Ed. PUC-Rio; São Paulo, Loyola, 2003.

. Escritos sobre educação (Sobre o futuro dos nossos estabelecimentos de ensino: III Consideração intempestiva - Schopenhauer como educador). Tradução de Noéli Correia de Melo Sobrinho, 2. ed. Rio de Janeiro: PUC-Rio; São Paulo: Loyola, 2004.

. Correspondencia II: abril de 1869 - dezembro de 1874.Traducción y notas a las cartas de José Manuel Romero Cuevas y Marco Parme- 
ggiani Introducción y apéndices de Marco Parmeggiani. Editorial Trotta, Madrid, 2007.

Escritos Sobre política. Trad. Noéli Correia de Melo Sobrinho. Rio de Janeiro: Editora PUC- Rio, vol. 1, 2007.

Ecce homo: como alguém se torna o que é. Trad. Paulo César de Souza. São Paulo: Companhia das Letras, 2008.

. Richard Wagner em Bayreuth. Quarta consideração extemporânea. Tradução de Anna Hartmann Cavalcanti. Editora Zahar, Rio de Janeiro, 2009.

. Assim falou Zaratustra, um livro para todos e para ninguém. Tradução de Mario da Silva. 18 a edição, Rio de Janeiro: Civilização Brasileira, 2010 .

SAFRANSKI, Rüdiger. Nietzsche: biografia de uma tragédia. Tradução de Lya Luft. São Paulo: Geração Editorial, 2001.

. Nietzsche. Biographie seines Denkens. Frankfurt am Main: Fischer TaschenbuchVerlag, 2005.

SALOMÉ, Lou Andrés. Nietzsche e Lou: In: Correspondências e outros documentos - Introdução, $1^{\mathrm{a}}$ edição, Via Verita, Rio de Janeiro, 2019.

SCHOPENHAUER, Arthur. O Mundo como Vontade e Representação. Tradução: Jair Barbosa. Rio de Janeiro: editora Contraponto, 2001.

WAGNER, Richard. Beethoven. Dichtungen und Schriften, vol. IX.Ed.de Dieter Borchmeyer. Frankfurt am Main: Insel, 1983. 
UMA CRÍTICA FILOSÓFICA À CRISTANDADE, SEGUNDO

KIERKEGAARD

\title{
A philosophical critique of christianity, according to Kierkegaard
}

\section{Adenilton Moisés da Silva ${ }^{1}$}

\begin{abstract}
RESUMO
Este trabalho é uma abordagem que busca analisar em algumas obras de Kierkegaard sua crítica a respeito da noção de Deus, sobretudo, a partir do cristianismo luterano de sua época. Religião esta profundamente marcada por um discurso idealista, com conceitos abstratos, de influências vindas do pensamento hegeliano. Busca-se, com este artigo, apresentar a impossibilidade, segundo Kierkegaard, de conceituar Deus através categorias objetivas ou dos dogmatismos religiosos. Apresentar-se-á Deus como sendo o Desconhecido, o Absoluto, o Paradoxo. Definições usadas para não definir nada de fato, apenas com o intuito de mostrar os limites do racionalismo; postulando que Deus pode ser conhecido mediante um vislumbramento da fé. O conhecer Deus é um pressuposto da fé, afirmando as limitações de uma ciência objetivista, ao mesmo tempo, recusando os dogmas religiosos, as trincheiras institucionais, narrando a incapacidade de abarcar a realidade de Deus. Diante disso, abre-se a possibilidade de romper com o Deus elaborado pelos discursos das instituições religiosas, na perspectiva de construir uma relação mais subjetiva entre "Eu e Deus".
\end{abstract}

Palavras-chave: Deus. Cristianismo. Desconhecido. Religião. Dogmas.

\begin{abstract}

\footnotetext{
${ }^{1}$ Universidade Católica de Pernambuco.

E-mail: adenilton.silva80@.gmail.com. ORCID: 0000-0002-2783-2857.
}

This work is an approach that seeks to analyze, in some works by Kierkegaard, his criticism of the notion of God, especially from the Lutheran Christianity of his time. Religion is deeply marked by an idealistic discourse, with abstract concepts, of influences from Hegelian thought. This article seeks to present the impossibility, according to Kierkegaard, of conceptualizing God through objective categories or religious dogmatisms. God will appear as the Unknown, the Absolute, the Paradox. Definitions used to define nothing at all, just to show the limits of rationalism; postulating that God can be known through a glimpse of faith. Knowing God is an assumption of faith, affirming the limitations of an objectivist science, at the same time, refusing religious dogmas, institutional trenches, narrating the inability to embrace the reality of God. In view of this, the possibility opens up to 
break with the God elaborated by the speeches of the religious institutions, in the perspective of building a more subjective relationship between "I and God".

Keywords: God. Christianity. Unknown. Religion. Dogmas.

\section{Introdução}

Este artigo se propõe a investigar a questão de Deus no pensamento kierkegaardiano. Por ser de raiz cristã luterana, questionando a perspectiva da época vigente, que fazia do cristianismo um discurso abstrato, contrariando a experiência religiosa como uma comunicação existencial, tornando-o um mero aglomerado de palavras abstratas, Kierkegaard, apresentará Deus como um Paradoxo, incompreensível aos desejos da razão. Desejos esses fundamentados num discurso científico da modernidade pretendido por muito pensadores pertencentes ao idealismo alemão. Todavia, Deus é uma relação dada na fé, na qual o sujeito, consciente da sua subjetividade descobre a sua comunicação com o Absoluto nos pressupostos da fé. Nesse contexto, a subjetividade da fé aparece como um caminho indispensável para se alcançar a verdade sobre Deus.

Como lidar com a consciência da sua subjetividade na formação de si enquanto indivíduo é outro problema inerente ao pensamento kierkegaardiano; a consciência da existência na subjetividade pelo indivíduo é o que possibilita a decisão na fé pela paixão paradoxal de conhecer quem é Deus. À medida que se avança no entendimento da análise sobre a formação da subjetividade humana, percebe-se o pressuposto da relação com Deus pelo dado da fé. Nesse momento, o homem como ser inserido no mudo, carece aprofundar o seu eu, decidir por si, assumir a responsabilidade dos seus atos, que examinando a si mesmo torne-se capaz de questionar as instituições que o amordaçam. Mais do que um questionamento à autoridade eclesial, é reconhecer que Deus está para além das normas institucionais.

Nota-se em Kierkegaard a ânsia de tirar do contexto teológico-filosófico racional o cristianismo. Ele constata que o cristianismo luterano não é o mesmo do Cristianismo do Novo Testamento. Essa religião, apontada por Kierkegaard, não pode ser vivida a partir dos postulados racionais dos seus intelectuais, muito menos, das normas estatais da Igreja Luterana. Para assu- 
mir o caráter de decisão na fé, o autor utiliza-se do conceito "homem crístico", com isso recusa a ideia de "homem intelectual", abandonando os paradigmas da ciência e os conceitos da metafísica institucional como pressupostos para o conhecimento de Deus. Tirar o cristianismo dessa inserção contextual será a tarefa paradoxal apaixonada desse autor. O seu problema é demonstrar os erros dos que se dizem cristãos ao tratarem de Deus via um princípio teórico, logicamente demonstrado e comprovado, e de terem negado ao cristianismo a sua essência, "uma comunicação existencial" entre o indivíduo e Deus.

\section{O Cristianismo}

Religião e não sistema filosófico, o Cristianismo é mais comunicação do que uma doutrina teórica com dogmas a serem decorados, ou quiçá compreendidos. É para ser vivido, na obediência aos mandamentos e, em primeiro lugar, o do amor ao próximo. Não constitui uma filosofia, que se explica, mas continua a ser, depois de dois mil anos, escândalo para os judeus e loucura para os gregos (isto é, irracionalidade para os filósofos gregos). E o amor que ele ensina, como tudo o mais que é "especificamente cristão" (crístico), é e tem que ser paradoxal (KIERKEGAARD, 2005, p. 10).

O cristianismo enquanto religião do martírio, do encantamento por Deus e pela criação, tem perdido o caráter de mistério. A sua vivência vem se definindo nas modalidades das correntes espirituais egoísticas e individualistas $^{2}$ segundo as novas interpretações da modernidade, há um deslocamento do eixo religioso; com isso, torna-se um rito terapêutico a controlar a ansiedade, a perda de paciência, de modo que, os que o procuram são comumente conduzidos a acreditarem que tudo em suas vidas devem ser tratado de maneira muito intimista; uma relação puramente abstrata que faz da realidade humana uma negação, que tende a distanciar os sujeitos das coisas hodiernas, através de uma transcendência desprovida de significado real. É nesse percurso que a fé é posta como um pressuposto para conhecer Deus ${ }^{3}$.

\footnotetext{
2 A noção de subjetividade em Kierkegaard não corresponde ao individualismo egoístico, ao isolamento, pelo contrário, trata-se da construção da personalidade humana de cada sujeito que se percebe na sua singularidade, enquanto ser no mundo, mas que se relaciona com o próximo.

3 “A Fé como pressuposto para conhecer Deus em Kierkegaard”, foi tema de dissertação de Mestrado, apresentada ao curso do programa de Pós-graduação em Ciências da Religião, da Universidade Católica de Pernambuco, 2019.
} 
Esse deslocamento religioso no contexto da sociedade pós-moderna interpreta a religião pelos paramentos do individualismo e da autossuficiência. Corre o risco de romper a ideia da relação existencial entre os sujeitos. Por isso, no pensamento de Kierkegaard, não há a possibilidade de interpretar esse fato como uma relação saudável, porque subtrai o princípio ético da experiência religiosa. Deus como o Absolutamente-Diferente é o outro que situa o indivíduo pelo compromisso "Tu deves amar". Se não é introduzido na atitude e não se toma consciência dessa necessidade, então, a relação é apenas uma ideia abstrata.

E assim um homem se compara com o outro, e aquele que compreendeu algo mais do que os outros já acredita ser alguma coisa. Quem dera que, caindo em si, pudesse compreender que diante de Deus ele não é nada. E dado que os homens querem tanto ser alguma coisa, não é de estranhar que eles, por mais que falem do amor de Deus, relutam tanto em se deixar realmente envolver por Ele, porque a exigência e seu critério os reduzem a nada (KIEREGAARD, 2005, p. 126).

É um cristianismo que nega a realidade, auxiliando-se numa idealização futura, abstrata, mas que exige a realização no aqui e no agora, profundamente imediatista, fazendo do sujeito religioso um estético no modo mais crítico que Kierkegaard descreveu na obra Temor e Tremor. Esse homem cristão da contemporaneidade, marcado pelo pluralismo religioso, é conduzido à ânsia de uma teologia abstrata e da prosperidade, das curas e dos milagres; obrigado a fugir da condição de homem real, limitado e carente de coisas e afetos.

O cristianismo compreendido por Kierkegaard é visto não como uma doutrina, mas, uma comunicação existencial, isto é, um encantamento pelos ensinamentos de Cristo, que busca salvar o homem da sua negação social. Contudo, os cristãos de hoje - ou pelo menos boa parte deles, buscam apenas o bem-estar prometido pela teologia da prosperidade, não se recordam do cristianismo vivenciado no martírio, pelo amor ao próximo (As Obras do Amor, 2005), antes procuram a prosperidade e o elogio das suas oratórias pronunciadas nos púlpitos eclesiais, "pois Lutero dizia ser preciso pregar nas ruas, mas infelizmente o dizia num púlpito de igreja" (KIERKEGAARD, 2005, p. 10). 
É contra essa religião do púlpito, dos altares das igrejas que se aliam ao Estado e partidos, que Kierkegaard descreve a sua crítica religiosa. Pois, na verdade, é um verniz religioso que não causa o desejo de mudança no crente, mas domesticando o fiel, o prende nas suas doutrinas e interesses pessoais, que é apenas de manter a subsistência institucional. Não se prega para libertar e salvar, mas para prender e fidelizar. Analisando os cristãos de cultura e/ou tradição, Kierkegaard procura fazer a sua crítica sobre a ideia de Deus, e de como Ele deve ser crido dentro da religião cristã.

Na concepção kierkegaardiana, o cristianismo não é, pois, relato histórico, mas uma possibilidade que se abre diante de cada indivíduo. $\mathrm{O}$ cerne passa a ser a paixão. Alguém pode ser apaixonado e não ser um cristão, tal como Feuerbach, e nem por isso sua paixão terá menos valor. Entretanto, no cristianismo, independentemente da paixão do indivíduo, a verdade do objeto é válida por ele mesmo, pelo Deus que lhe é exterior (PAULA, 2009, p. 28).

O cristianismo apontado por Kierkegaard não é entendido como um fato histórico. Desde que, o indivíduo se relacionar com o cristianismo por meio da fé, sem a necessidade da religião institucional, torna-se uma adesão pessoal, assumindo-a como uma possibilidade aberta a si mesmo, tendo o seu valor em si mesmo, não carecendo das explicações dogmáticas, nem da mediação eclesial. Tal aprendizagem na fé sobre o Cristianismo do Novo Testamento ensina que o Deus com o qual se relaciona é-lhe exterior e interior ao mesmo tempo. Essa dialética relacional indica que Deus é o OutroAbsolutamente-Diferente, por isso é-lhe exterior, como também é interior, pois esse Outro só pode ser alcançado pela interioridade da fé. Isso muda toda a perspectiva da relação e do entendimento humano consigo e com a religião cristã. Não é somente a paixão racional que está a mover a sua intencionalidade, mas a descoberta do Outro que lhe supera nas suas compreensões de si mesmo e do mundo, no descobrimento da paixão paradoxal da fé. Kierkegaard trabalha com palavras contraditórias para expressar a dificuldade da linguagem em dizer quem é Deus.

Quando na religião cristã, especificamente se tratando do luteranismo dinamarquês, entra a noção de absurdo, o desejo do autor de Temor e Tremor é mostrar a impossibilidade de falar de Deus como um conhecimento inteligível, objetivado como dado da razão, demonstrado em fatos palpá- 
veis, pelo contrário, conhecer Deus é uma ação que acontecerá via a paixão movida pela fé na esfera da subjetividade, que o autor denomina como um salto qualitativo. Quando a inteligência não consegue meter o paradoxo na cabeça, não é ela quem o inventou, mas o paradoxo mesmo, que seria bastante paradoxal para não ter escrúpulos de dizer que a inteligência é tão estúpida, que diante de uma mesma coisa no máximo diz sim e não (KIERKEGAARD, 2008, p. 81).

No pensamento kierkegaardiano Deus está para além do discurso religioso. A linguagem não tem aprimorado a relação entre "eu e Deus", apenas criado uma atmosfera de recusa ao mundo e uma existência relativa equivocada, semelhante à do movimento monástico ${ }^{4}$, e, ao mesmo tempo, uma certa nostalgia mental. Quando esse autor analisa a linguagem mística na obra Ou - Ou: um fragmento de vida, segunda parte, encontra o que identificamos como nostalgia mental, isto porque, trata-se de uma condição fundada no nível metafísico:

$\mathrm{Na}$ linguagem do místico, esta relação livre é muitas vezes expressa desta forma: ele é o tu absoluto. O místico escolheu-se a si mesmo em absoluto e, portanto, de acordo com a sua liberdade e, portanto, é eo ispso agente, mas a sua ação é uma ação interior. O místico escolhe-se a si mesmo no seu mais completo isolamento, o mundo inteiro está para ele morto e aniquilado, e a alma cansada, não tem de ser mal entendida nem usada erradamente para apoucamento do místico, como se fosse assunto escabroso a alma só escolher Deus quando ficasse cansada do mundo. É indubitável que através desta expressão o místico designa seu arrependimento pelo fato de não ter previamente escolhido Deus, e o seu cansaço não tem de ser considerado como idêntico a estar farto da vida (KIERKEGAARD, 2017, p. 246).

\section{Deus para além da Religião}

Na obra Migalhas Filosóficas, sobre o pseudônimo de João Climacus, Kierkegaard introduz a noção de Paradoxo e Absurdo para falar de Deus; tenta desconstruir toda a imagem fabricada pelos bispos da Igreja Luterana da Dinamarca a respeito do cristianismo e das falsas testemunhas que

\footnotetext{
4 O equívoco do movimento monástico (abstraindo-se do erro do presumido merecimento) estava em que a interioridade absoluta, provavelmente para demonstrar de forma bem enérgica que existia, adquiriu sua expressão óbvia numa exterioridade específica distinta, por meio da qual esta se torna, contudo, apenas relativamente diferente de todas as outras exterioridades, como quer que seja (KIERKEGAARD, 2016, p. 122).
} 
se elegem como verdadeiros crentes. Essa ideia é encontrada na obra $O$ Instante, onde é reelaborada uma severa crítica aos pastores e os seus discursos desencontrados sobre a verdade existente nos Evangelhos. Conhecer o Paradoxo, isto é, Deus, deixa a inteligência numa contradição de si. Para compreender de fato Deus, precisa-se do movimento efetuado pela paixão paradoxal da inteligência; contradição causada quando a paixão se depara com esse Desconhecido, que de fato existe, mas permanece desconhecido e inexistente. Esse Desconhecido, em Kierkegaard, é o Deus como mestre e salvador, o qual não é totalmente compreendido pela paixão da inteligência.

A inteligência não pode ir mais longe: mas o seu sentido de paradoxo leva-a a aproximar-se do obstáculo e a ocupar-se dele; porque, pretende exprimir a sua relação com ele negando a existência daquele desconhecido, não dá certo, visto que o enunciado desta negação envolve precisamente uma relação. Mas o que é então este desconhecido (pois dizer que ele é o deus significa simplesmente que ele é para nós desconhecido)? Enunciando-se sobre ele que é o desconhecido, dado que não se pode conhecê-lo, e que, se mesmo assim se pudesse conhecê-lo, não se poderia enunciá-lo, a paixão não se dará por satisfeita, embora ela tenha captado corretamente o desconhecido como limite: mas o limite é justamente o tormento da paixão, ainda que ao mesmo tempo seu incitamento. E, no entanto ela não consegue ir mais adiante, quer ela arrisque uma saída via negationis, quer via eminentiae (KIERKEGAARD, 2008, p. 71).

O que busca a inteligência racional é romper limites, embora use de malabarismos, na intenção de tornar o Desconhecido um objeto conhecido empiricamente, de modo que, ela seja a suprema compreensão da realidade. Todavia, essa paixão movedora, que a inteligência dispõe em si mesma, é portadora do elemento paradoxal, isto é, tem o seu limite de conhecimento, não dá conta de abarcar o todo da realidade que investiga. Significa dizer que, ao chegar ao limite do conhecimento almejado pela própria inteligência, ela percebe a presença do Paradoxo, do Desconhecido, ficando presa na incognoscibilidade. O Desconhecido tornar-se-á conhecido para logo em seguida voltar a ser novamente desconhecido quando se usa do salto qualitativo da fé.

Essa dialética, Kierkegaard a chame de "paixão paradoxal da inteligência”. Esse jogo dialético insere a compreensão do Desconhecido entre o ato cognoscível e a incognoscibilidade, isto é, o pensamento não consegue abarcar toda a contradição que existe, apenas aproximar-se quando o Para- 
doxo dá a condição que é a fé, sobretudo, porque, "a própria fé é um milagre, e tudo o que vale para o paradoxo vale também para a fé” (KIERKEGAARD, 2008, p. 95), portanto, não é possível provar a existência de Deus historicamente.

O pensamento se esgota diante do inesgotável ${ }^{5}$, por isso, Kierkegaard propõe a noção de Deus dentro do paradigma do Paradoxo, ou seja, aquele impronunciável totalmente, permanecendo desconhecido no limite entre a verdade e a não-verdade do discípulo. Diante desse paradigma religioso se confrontam o pensador subjetivo e o pensador objetivo nos seus modos existenciais. No cristianismo, segundo Kierkegaard, o discípulo é sempre a condição da não-verdade; para que chegue à verdade em si, é preciso que Deus a possibilite pela condição, isto é, a fé no Paradoxo. Tendo feita a aquisição da fé, o discípulo é questionado a tornar-se cristão segundo o modelo do Cristianismo do Novo Testamento. Nesse estádio religioso são confrontadas as atitudes do indivíduo com aquelas que estão a ser ensinadas nos Textos Sagrados, sem a intervenção manipuladora da instituição, que tenta adoçar os ensinamentos do Cristianismo, interessa-se, agradar uma ala de líderes, que buscar ludibriar a sociedade com falsos testemunhos e com discursos abstratos.

Kierkegaard, por intermédio do seu pseudônimo Clímacus, sugere que se dê a esse desconhecido o nome de "o deus". Deste modo, Clímacus confessa que Deus não é senão um nome e entende por esse "nome" uma denominação pura e simples para designar "a coisa desconhecida", "o desconhecido" com o qual se depara o homem, radicalmente não simbolizável. Mas, se Deus é o limite da esfera do conhecido, o além do conhecido, toda a afirmação sobre Deus é nua de sentido. Há coisas que a linguagem não pode dizer e, se mesmo assim a linguagem fala sobre elas, estas se transformam em outra coisa, passando da "existência" à "abstração" do pensamento privado de referências, mas então a linguagem está desconectada do sentido, dado que este só pode ser existencial (FARAGO, 2006, p. 201).

$\mathrm{Na}$ perspectiva do corpus kierkegaardiano, "Deus não é um nome, mas um conceito" (KIERKEGAARD, 2008, p. 66), que pode ser dito infinitamente, mas isso não oferece nenhum conhecimento definitivo a cerca da verdade que Ele é, apenas especulações, visto que, não pode ser abarcado

${ }^{5} \mathrm{O}$ entendimento conta e reconta, calcula e calcula, mas jamais alcança a certeza que a fé possui; assim também a lei, ela determina e determina, mas nunca chega à soma global que é o amor (KIERKEGAARD, 2005, p. 129). 
plenamente pela intelecção, existindo na impossibilidade cognitiva de expressar o ser em geral. Delimita-se a consciência a viver presa no mundo da parcialidade, dos conceitos postulados pela inteligência, "pois os conceitos, assim como os indivíduos, têm a sua história e, tal como eles, não conseguem resistir ao poder do tempo" (KIERKEGAARD, 2005, p. 23). Nesse contexto tem vivido os pregadores da Igreja Luterana da Dinamarca. Todos esses querem se apossar de Deus pelo intelecto ${ }^{6}$, deixando de lado o testemunho de uma vida pautada na ética e na caridade evangélica, apenas buscam falar de Deus em conceitos no intuito de mostrarem-se intelectuais, que tem como finalidade, adquirirem os melhores púlpitos eclesiais oferecidos pelo Estado dinamarquês.

Para Kierkegaard, "o deus"” se desfigura de um conceito, assume a condição de existente encarnado, torna-se outro indivíduo a ser compreendido por outro sujeito na e pala relação no instante. Ele pretende ultrapassar a conceitualização do nome de Deus, levar o homem religioso, como também, a religião, à descoberta da verdade subjetiva para conhecer Deus, diferente do que a filosofia alemã postulava. Para "Hegel o pensamento não precisa ser interrogado desde fora; pois este pergunta e responde a si mesmo" (KIERKEGAARD, 2005, p. 41). O “objeto é uma divergência a ser ajustada entre aquele que pergunta e aquele que responde e o desenvolvimento do pensamento se consuma neste passo alternado (alterno pede), neste claudicar de ambos os lados" (KIERKEGAARD, 2005, p. 41).

Enquanto a religião cristã dinamarquesa estava presa nas categorias do pensamento, sempre perguntando e afirmando quem é Deus, as suas réplicas não respondiam à identidade do indivíduo, este continuava a sentir-se desamparado, as suas dores e angústias não encontravam entendimento nas construções metafísicas da teologia vigente. $\mathrm{O}$ cristianismo estava longe dos anseios de cada sujeito, preso na coletividade institucional gerenciada pelos

\footnotetext{
${ }^{6}$ Deus é imutável. Na sua onipotência, ele criou este mundo visível - e se fez invisível. Ele vestiu-se no invisível mundo como que com uma roupa - ele mesmo imutável. Assim é no mundo das coisas sensíveis. No mundo dos eventos, ele está presente em toda a parte e em todo o momento; em um sentido mais verdadeiro do que podemos dizer da mais atenta justiça humana que está em todos os lugares (PAULA apud KIERKEGAARD, 2000, p.134).

7 Para não usar o nome "Cristo", Kierkegaard usa a expressão "o deus", ao mesmo tempo, refere-se à encarnação de Deus na história da humanidade (grifo nosso).
} 
bispos, tornava-se uma metáfora, um sistema de sustentabilidade intencional que mantinha os interesses hierárquicos da classe dominante, essa mesma gerava uma dependência da grande massa dos fiéis, os quais não interrogavam a igreja estatal. Ao levantar a voz crítica, Kierkegaard vai minar as estruturas dessas instituições e o arcabouço intelectual predominante na academia dinamarquesa. "A felicidade da fé, ao contrário, está nisso, que Deus é amor. Daí não se segue que a fé compreenda de que modo o desígnio de Deus para com um ser humano é amor. Aqui está justamente o combate da fé: crer sem poder compreender” (KIERKEGAARD, 2018, p. 138).

Sendo do "período pós-hegeliano", Kierkegaard ao utiliza-se das expressões Paradoxo ou Absurdo está se referindo ao "deus", o escândalo para judeus e a loucura para os gregos. Está desse modo, criticando todo o discurso racional que adentrou a Igreja Luterana. Essa predominância entre os pastores, vistos como funcionários do Estado, tem causado uma letargia da fé. Está em cheque a fé no Cristianismo do Novo Testamento, para dá espaço à obediência àqueles que são as autoridades instituídas pelos ritos religiosos.

Se o que o Cristianismo do Novo Testamento queria era: honestidade e sinceridade, fora com a enganação - a mudança que foi produzida é esta: a enganação continua exatamente como o paganismo, "Cada um" (cristão!) "é ladrão em seu ofício", mas a enganação assumiu o predicado "cristão", passou a ser enganação "cristã" - e o "pastor" abençoa essa sociedade cristã, esse Estado cristão, onde a gente engana como no paganismo e, também, ao pagar o "pastor", portanto, o maior dos enganadores, engana-se a si mesmos tomando isso por Cristianismo (KIERKEGAARD, 2019, p. 119).

O Deus do Cristianismo do Novo Testamento é escândalo, loucura revelando-se dentro de uma relação paradoxal, é atingido na compreensão cristã quando essa condição é vivenciada pelo homem crístico. A sociedade cristã, o Estado cristão tem burlado tal religião, introduzindo uma mudança de eixo, ao nível de um status social sem implicação que deveria gerar em cada sujeito o desejo de tornar-se cristão por adesão e vivência de um testemunho arraigado na relação ética e responsável pelo Outro-AbsolutamenteDiferente, mas promovendo barganhas internas, os institucionalizadores trocam interesses em função de títulos e posições. 
Na obra Temor e Tremor, o autor pseudonímico revisita o problema de Abraão e sua relação com o filho Isaac, Johannes de Silentio, discute uma questão de caráter teleológica, trata dos fins necessários, dos propósitos do ato de ser no mundo. Essa situação não é apenas o "estar aí", mas tomando consciência de si, investe numa decisão absoluta. As barganhas perdem interesses, as posições não importam, mas na construção de uma identidade consciente de si, trabalha-se com os interesses edificantes da personalidade, que visa tornar-se um autêntico cristão. Tal movimento interior não é discursivo, mas um paradoxo existencial. Essa dupla categoria Paradoxo/Absurdo na relação da fé estabelece, ao mesmo tempo, o diálogo com Deus, que ultrapassa todo o racionalismo e as suas categorias da aquisição do conhecimento, como também, a edificação da existência, que é um problema em si mesma, vindo a ser investigada interiormente, pois tem o seu fim em si mesma, dada na condição da fé relevada no modo como Deus ama o ser humano.

\section{Afirma Kierkegaard em O Matrimônio:}

Quando declaro que Deus é incompreensível, minha alma se eleva ao Todo Poderoso, e o afirmo nos momentos de felicidade suprema, posto que é incompreensível, porque o é seu amor, e porque seu amor excede a todo o entendimento. Aplicada a Deus, esta palavra, incompreensível designa a perfeição suprema; ao contrário, se a aplicamos ao homem revela sempre um defeito, e, às vezes, um pecado (KIERKEGAARD, 1969, p. 16).

Deus, isto é, o Absoluto como Desconhecido, o Incompreensível nos remete ao paradoxo que afronta o intelecto no limite presente no pensamento. O cristianismo luterano almejou tirar esse paradoxo, e introduzir um dado fenomenológico historicamente comprovado via, interpretações sistemáticas dentro da sua teologia universitária. Assim, com a autoridade eclesiástica provando Deus como fato, um sistema teológico, então, todo o poder fundamenta-se numa prova construída pela hierarquia, e essa não se preocupa com a verdade presente no Cristianismo do Novo Testamento, mas em manter-se detentora da sua pseudoverdade estabelecida em cânones jurídi$\cos$.

Dizer que Deus é o Desconhecido que toca o tempo, é afirmar que Ele toca num instante enquanto acontecimento único a realidade humana. A 
sua encarnação vista como manifestação, implica para o sujeito uma primeira percepção imediata e um conhecimento imediato que o afeta num dado instante em que Ele se encarna como "o deus". Dessa forma, Kierkegaard busca mostrar a impossibilidade de traduzir o cristianismo em relatos históricos ou de ser tratado como uma filosofia da religião, como também demonstra ser uma tentativa fracassada fazer de Deus uma ideia abstrata, uma dúvida hiperbólica, ou simplesmente querer dar provas da existência de Deus.

O intelecto pode pensar o infinito, mas não o "absurdo", porque é absurdo para o pensamento, constitutivamente intranscendível, predispor-se ao encontro com aquilo que o transcende, mas que, ao mesmo tempo, o salva da indiferença por si mesmo. Enquanto o infinito do intelecto distrai o existente do seu próprio existir, o absurdo da fé tudo redime, consentindo que ele faça de sua mesma existência uma "nova criação". "Pelo absurdo", o cavaleiro da fé sabe se mover no mundo com a segurança de quem controla perfeitamente as próprias forcas (REGINA, 2016, p.74).

A fé pode ser objeto do entendimento enquanto conceito, isto é, objeto da dúvida, mas enquanto verdade paradoxal só pode ser vivida e crida, pois sendo o oposto da dúvida, ela é a exigência última da determinação da formação da personalidade do crente.

A fé é o oposto da dúvida. Fé e dúvida não são duas espécies de conhecimento que se deixam determinar no prolongamento uma da outra; pois nenhuma das duas é um ato de conhecimento, e elas são paixões opostas. A fé é o sentido que capta o devir, e a dúvida, o protesto contra toda conclusão que quer ir além da percepção imediata e do conhecimento imediato. $\mathrm{O}$ duvidador não nega, por exemplo, sua própria existência, mas não conclui nada; pois não quer ser iludido (KIERKEGAARD, 2008, p. 123).

O Cristianismo quer apenas revelar, no contexto da fé, uma verdade que seja válida para a interioridade do ser humano, e que está seja-lhe a causa pela qual ele possa existir enquanto consciência de si e responsabilidade pelo outro. "A verdade - nas palavras de Kierkegaard - não era introduzida de fora no indivíduo, mas estava dentro dele" (GARDINER, 2001, p. 79). Ela é encontra no momento da escolha, quando o ser humano elege a si mesmo numa responsabilidade ética, num compromisso religioso inerente ao seu ser no mundo, que o coloca numa situação perante o Outro-Absolutamente-Diferente. Essa compreensão também foi percebida na obra intitula- 
da, Soren Kierkegaard: Subjetividade, Ironia e a Crise da Modernidade. Ela afirma:

Kierkegaard queria evitar dar a impressão de que ele pretendia ensinar as pessoas, e de que elas só precisavam seguir suas instruções. Acreditava que o cristianismo só tinha sentido se o próprio crente tivesse uma experiência com ele. Portanto, uma crença vicária baseada somente na autoridade dos ensinamentos de outra pessoa era insuficiente e até mesmo enganadora. Em vez disso, Kierkegaard insistia que o cristianismo se refere totalmente a uma relação interior de cada indivíduo, e seu objetivo, então, era ajudar as pessoas a encontrar essa relação em si mesmas. Portanto, assim como Sócrates, Kierkegaard acreditava que ele poderia facilitar esse encontro, mas, em última instância, era a outra pessoa quem estaria tendo o trabalho de descobrir a verdade, ou a relação interior, por si mesma (STEWART, 2017, p. 38).

Deus é a verdade subjetiva no indivíduo, a qual se pressupõe ser adquirida na relação interior de cada sujeito, não vislumbrando interferências objetivas para alcançar essa finalidade, senão a fé revelada pelo Cristianismo do Novo Testamento. Essa verdade é dada na esfera do imediatismo, ou seja, quando "o deus" entra no tempo, este tocado num instante presente, isto é, transforma-se na plenitude dos tempos, visto que o Deus criador assume a condição humana, encarnando-se.

Um tal instante tem uma natureza própria. Sem dúvida é breve e temporal como o é todo instante, passando, como todos os outros, ao instante seguinte, e, no entanto é o decisivo, pleno de eternidade. Um tal instante deve ter com efeito um nome especial; vamos chamá-lo: plenitude dos tempos (KIERKEGAARD, 2008, p. 38).

Em Kierkegaard compreendemos que o Absurdo é a entrada de Deus na história, isto é, o tempo é tocado pela eternidade, "o Verbo se fez Carne"» O Absurdo é manifestado quando a verdade eterna entra no tempo pela categoria do instante. Poderíamos chamar esse evento de epifania do Paradoxo. Que Este tenha aparecido, como também nascido e crescido, ou seja, feito carne do mesmo modo que o homem, podendo ser distinguido de outro sujeito, eis o Absurdo, o Paradoxo, em outras palavras, escândalo e loucura para a racionalidade.

Por não se adequar às categorias lógicas, é aceite como paradigma metafórico de uma linguagem mitológica. É contraditório sim, ter um Deus

8 Cf. João $1,1-18$. 
que se manifeste no tempo como homem, que tenha aparecido, nascido e crescido. Kierkegaard concebe Deus como sendo um indivíduo subjetivo, a condição existencial que eleva o sujeito à sua mais profunda transformação e edificação da sua identidade humana. Para ele, Deus é a verdade como manifestação de si mesmo. Ele atua no sujeito não por uma transferência metafísica, mas espontaneamente se move pelo amor eterno em si mesmo.

Mas o deus não precisa de nenhum discípulo para compreender-se a si mesmo; e assim nenhuma ocasião pode agir sobre ele de modo a equivalerem ocasião e decisão. Que é que pode, então, movê-lo a apresentar-se? Ele tem de mover-se a si mesmo e continuar sendo o que Aristóteles diz dele: "Sem mover-se move tudo"... Porém se ele se move, então não é uma necessidade que o faz mover-se, assim como se não pudesse suportar o silêncio, mas precisasse irromper na palavra. Mas se não é por necessidade que se move, o que é que o move, o que será, senão o amor? Pois o amor justamente não tem a satisfação do desejo fora dele, mas em si mesmo. Sua decisão, que não entretém uma relação recíproca direta com a ocasião, deve existir desde toda a eternidade, embora, realizando-se no tempo, ela se torne justamente o instante, pois aí onde a ocasião e o ocasionado se correspondem diretamente, exatamente como no deserto a resposta ao grito, aí o instante não aparece, porém a reminiscência o engole em sua eternidade. $\mathrm{O}$ instante vem à luz justamente pela relação da decisão eterna para com a ocasião que lhe é desigual. Se não for assim desta maneira, recairemos no socrático e então não alcançaremos o deus, nem a decisão eterna, nem o instante (KIERKEGAARD, 2008, p. 46).

Ao apresenta a ideia da imutabilidade de Deus, Kierkegaard dizendo da impossibilidade de conhecer Deus por conceitos científicos ou dogmas religiosos. Se houvesse a mutabilidade de Deus, deixaria de existir o paradoxo e o absurdo em que a fé acredita e postula como verdade interior. A verdade que está descrita no Cristianismo do Novo Testamento, e que continua oculto na religião institucional, é justamente a presença irrevogável do amor. Esse amor se torna justamente um instante porque se manifesta no tempo quando ama o outro, o seu desejo não subtrai outra realidade, mas vive em si mesmo a sua única realidade temporal que é expressar-se como amor em tempo integral. Seu objeto é o próprio amor, não o outro enquanto necessidade alheia, mas o outro enquanto condição de amar sem ser algo alheio, mas como tarefa única do amor. Por isso, o Cristianismo do Novo Testamento, na perspectiva de Kierkegaard, não é encontrado dentro da instituição, mas essa construiu as suas colunas templárias sufocando a verdade, 
e implantando o comércio religioso-estatal. Deus se esconde entre as colunas do tempo e do templo. Não se consegue ver o altar ou a mesa da palavra sagrada, apenas se contempla o circo montado por meia dúzia de sofistas religiosos, fantasiando a fé e ludibriando para que não se tenha acesso à vida em plenitude.

\section{Considerações finais}

Em Kierkegaard, a noção de Deus é mais que um conceito ou dogmas religiosos, é uma experiência de fé vivida e crida na cotidianidade das coisas e das experiências humanas, que está além da religião institucional. É um encantamento com a própria vida. Há de se concordar com Kierkegaard, o cristianismo deve ser transmitido e vivido na perspectiva de uma experiência existencial; capaz de produzir no indivíduo uma relação concreta com Deus sem os intermédios eclesiásticos. O Cristianismo do Novo Testamento não é resumo das interpretações da hierarquia.

Os títulos eclesiásticos mais afastam do que aproximam os fiéis. Quando se invertem os valores e fé, cria-se a submissão aos dogmas, relegando a autoridade do Evangelho e transferindo-a a instituição. Troca-se a liberdade, passa-se a investir na obediência à autoridade, que muitas das vezes oprime a consciência individual, tornando-a um objeto de manipulação social. Kierkegaard é dos autores que consegue a sua liberdade de consciência, propõe um cristianismo baseado na prática do princípio ético e misericordioso, e não nos sermões apologéticos do luteranismo estatal.

\section{Referências}

FARAGO, France. Compreender Kierkegaard. Trad. Ephaim F. Alves. Petrópolis: Vozes, 2006.

GARDINER, Patrick. Kierkegaard. Trad. Antônio Carlos Vilela. São Paulo: Loyola, 2001.

KIERKEGAARD, Soren. As Obras do Amor. Trad. Álvaro L. M. Valls. Bragança Paulista: Ed. Universitária São Francisco; Petrópolis: Vozes, 2005. 
KIERKEGAARD, Soren. Discursos Edificantes em Diversos Espíritos 1847. Trad. Álvaro L. M. Valls e Else Hagelund. São Paulo: Editora LiberArs, 2018.

KIERKEGAARD, Soren. Migalhas Filosóficas ou um Bocadinho de Filosofia de João Clímacus. Trad. Ernani Reichmann e Álvaro L. M. Valls. $2^{\mathrm{a}}$ edição. Petrópolis: Vozes, 2008.

KIERKEGAARD, Soren. O Conceito de Ironia Constantemente Referido a Sócrates. Trad. Álvaro L. M. Valls. $2^{a}$ edição. Bragança Paulista: Ed. Universitária São Francisco, 2005.

KIERKEGAARD, Soren. O Instante. Trad. Álvaro L. M. Valls e Márcio Gimenes de Paula. São Paulo: Editora LierArs, 2019.

KIERKEGAARD, Soren. O Matrimônio. Trad. Rodolfo Konder. Rio de Janeiro: Laemmert S.A, 1969.

KIERKEGAARD, Soren. Ou - Ou: um fragmento de vida (segunda parte). Trad. Elisabete M. de Sousa. Lisboa: Relógio D’Água, 2017.

KIERKEGAARD, Soren. Pós-Escrito Conclusivo não Científico às Migalhas Filosóficas, Vol. I. Trad. Álvaro L. M. Valls e Marília Murta de Almeida. Bragança Paulista: Ed. Universitária São Francisco; Petrópolis: Vozes, 2013.

KIERKEGAARD, Soren. Pós-Escrito Conclusivo não Científico às Migalhas Filosóficas, Vol. II. Trad. Álvaro L. M. Valls e Marília Murta de Almeida. Bragança Paulista: Ed. Universitária São Francisco; Petrópolis: Vozes, 2016.

KIERKEGAARD, Soren. Temor e Tremor. Trad. Maria José Marinho. São Paulo: Abril Cultural, 1979.

PAULA, Márcio Gimenes de. Indivíduo e Comunidade na Filosofia de Kierkegaard. São Paulo: Paulus, 2009.

REGINA, Humberto (2016). Kierkegaard. Trad. Alessandra Siedschlag. São Paulo: Ideias e Letras.

SILVA, Adenilton Moises da. A Fé como Pressuposto para conhecer Deus em Kierkegaard. 151f. Dissertação (Mestrado em Ciências da Religião), Programa de Ciências da Religião - Universidade Católica de Pernambuco. Recife, 2019.

STEWART, Jon. Soren Kierkegaard: subjetividade, ironia e a crise da modernidade. Trad. Humberto Araújo Quaglio de Souza. Petrópolis: Ed. Vozes, 2017. 


\title{
FAKE NEWS E COLONIALIDADE DE MENTES: CONSIDERAÇÕES VIA PARADIGMA DA COMPLEXIDADE
}

\author{
Fake News and coloniality of minds: considerations through the \\ paradigm of complexity
}

\section{Juliana Moroni ${ }^{1}$}

\begin{abstract}
RESUMO
Neste artigo, nós buscamos compreender como a disseminação de fake news, através do uso de tecnologias digitais, tornou-se uma ferramenta poderosa na manipulação da opinião pública, contribuindo para o processo de colonialidade $^{2}$ de mentes. A colonialidade de mentes, contextualizada nos estudos de Dascal (2009), é um tipo de violência epistêmica, caracterizada como transmissão e modificação de hábitos através de sistemas sociais como família, linguagem, religião, ciência, educação, ideologia e mídia que disseminam as formas de imposição do pensamento e ação do colonializador. Nossa hipótese é a de que o paradigma da complexidade, fundamentado no pensamento de Morin (2003; 2005), oferece subsídios teóricos para pensarmos o problema da disseminação de fake news, bem como a sua influência na colonialidade de mentes na medida em que expressa uma visão de mundo não fragmentada e sistêmica, pautada por princípios como o hologramático e o dialógico. Com base nestes princípios, nosso principal foco será oferecer um caminho para pensarmos sobre a colonialidade de mentes através da ética da complexidade.
\end{abstract}

Palavras-chave: Fake News. Tecnologias Digitais. Colonialidade de Mentes. Solitude. Paradigma da Complexidade.

\begin{abstract}
In this work, we try to to understand how the spread of fake news, through the use of digital technologies, has become a powerful tool in the manipulation of public opinion, contributing to the coloniality of minds. The coloniality of minds, contextualized in the studies of Dascal (2009), is a type of epistemic violence which is characterized as transmission and modification

\footnotetext{
${ }^{1}$ Universidade do Estado do Rio de Janeiro e Universidade Estadual Paulista. E-mail: julianamoroni@yahoo.com.br. ORCID: 0000-0002-4878-4823.

2 Não há um consenso acerca do uso dos termos colonização/descolonização e colonialidade/decolonização. Sendo assim, como veremos no decorrer deste texto, optamos por utilizar o termo colonialidade, decolonialização, decolonialidade, colonializador e colonializado ao invés do termo colonização e descolonização de mentes. Adaptamos a terminologia usada por Dascal (2009), colonizing e decolonizing minds, bem como por Walsh (2009), decoloni$a l$, à terminologia que optamos por utilizar, no contexto de nossa análise, sem alterar o sig nificado que os autores propuseram.
} 
of habits through social systems such as family, language, religion, science, education, ideology and media which disseminate imposing forms of the colonizer's thinking and acting. Our hypothesis is that the complexity paradigm, based on the thought of Morin $(2003 ; 2005)$, offers theoretical support for thinking about the problem of the spread of fake news, as well as its influence on the coloniality of minds as it expresses a non-fragmented, systemic world view guided by principles such as holographic and dialogic. Based on these principles, our main focus will be to offer a way to think about the coloniality of minds through the ethics of complexity.

Keywords: Fake News. Digital Technologies. Coloniality of Minds. Solitude. Paradigm of Complexity.

\section{Considerações iniciais}

A “era do algoritmo" tem possibitado a disseminação rápida e abragente de fake news, informação espúria que, antes do desenvolvimento das tecnologias digitais, tinha o seu alcance mais restrito, não causando tantos danos às reputações e, principalmente, aos sistemas democráticos. Auxiliada pelas tecnologias digitais, fake news se tornaram uma ferramenta importante na colonialidade de mentes, gerando crenças nas quais a verdade fica em segundo plano ou se torna inexistente, criando e alterando hábitos de ação.

Neste artigo, propomos uma investigação epistemológica sobre a relação entre fake news e colonialidade de mentes no contexto do paradigma da complexidade. Na seção 2, caracterizamos o conceito de fake news, de acordo com os três tipos propostos por Wardle e Derakhshan (2017), quais sejam, misinformation, disinformation e malinformation, refletindo sobre os seus impactos em filtros-bolha e no atrofiamento do pensamento crítico.

Na seção 3, analisamos a relação entre fake news e colonialidade de mentes mostrando o desequilíbrio de poder entre colonizador e colonizados, no contexto do que Mariconda (2019) designou como estado de exceção tecnológica, oriundo da colonialismo digital realizado pelos oligopólios transnacionais, as Big Techs (KWET, 2021). Questionamos até que ponto o modelo de sistema misto, o qual inclui abordagens conflitantes de colonialidade de mentes, a fim de possibilitar o próprio pensamento, como sugere Dascal (2009), é prejudicado pelas bolhas virtuais por onde circulam informações homogêneas. 
$\mathrm{Na}$ seção 4, argumentamos que, no contexto da teoria da complexidade proposta por Morin $(1977 ; 1995 ; 2003 ; 2005)$, as possíveis medidas de combate às fake news não terão a eficácia desejada se não mudarmos a nossa percepção da realidade. Essa percepção é ampliada pelo pensamento complexo, a partir do qual somos partes do todo e, qualquer alteração nas partes, implica mudança no todo. A nossa percepção da realidade e de como somos colonializados através de fake news pode ser beneficamente alterada se adotarmos a visão de mundo pautada pela ética da complexidade.

Nas considarações finais, seção 5, expomos que a proposta de Dascal (2009) de sistema misto se aproxima do paradigma da complexidade através do princípio dialógico que, segundo Morin (1977; 1995; 2003; 2005), expressa a unidade complexa entre elementos que se completam e que se opõem, indicando a importância da permanência de antagonismos a fim de gerarem entidades ou fenômenos complexos. A permanência destes antagonismos torna a opinião pública heterogênea, sendo fundamentais para a manutenção de sistemas democráticos.

\section{Fake News, algoritimos e tecnologias digitais: a ausência de solitude e do pensamento crítico}

O termo fake news se tornou popularizado e usado desenfreadamente, sobretudo, a partir das eleições presidenciais norte-americanas, em 2016, cujo candidato eleito foi Donald Trump e com o Brexit, saída do Reino Unido da União Europeia. Fake news é um termo reciclado e utilizado na contemporaneidade para caracterizar informações que transmitem conteúdos que não se apoiam ou se apoiam de modo parcial na realidade. A verdade fica em segundo plano ou é algo inexistente. Fake news não são novidade nas relações humanas; a novidade é a sua ampla e rápida disseminação através da evolução das tecnologias da informação e comunicação (TICs), impactando na opinião pública, nas relações entre indivíduos e grupos sociais, bem como politicamente em sistemas democráticos.

Neste trabalho, o termo fake news não será traduzido para a língua portuguesa. Isso porque ele é mais abrangente na língua inglesa do que a sua tradução para a língua portuguesa, como notícias falsas. Consideramos mais 
abrangente o termo na língua inglesa dado que o adjetivo falso que, de acordo com o Dicio (dicionário Online de Português), é caracterizado como: “contrário à verdade; sem correspondência com a realidade. Que oculta o que realmente pensa. Que aparenta ser real, mas não é; cujo conteúdo foi adulterado, modificado; feito por imitação; desprovido de fundamento, de exatidão; [..]". Nesse sentido, ao ser definido como sem correspondência com a realidade, o termo fake news se torna significativamente mais amplo, dado que engloba tanto notícias falsas, como também notícias não totalmente falsas, mas que tem alguma correspondência com a realidade, criadas e disseminadas com objetivo de causar prejuízos ou propagadas inintencionalmente (MORONI, 2018).

Segundo Recuero e Gruzd (2019, p. 32-33), há diversas caracterizações do termo fake news. Atualmente, ele é caracterizado como desinformação que abrange rumores e notícias falsas. Entretanto, há outras conceitualizações para o termo fake news que abrangem desde notícias falsas a boatos e sátiras. A fim de delimitar o conceito de fake news, Recuero e Gruzd (2019) afirmam que boatos não são considerados fake news na medida em que não expressam intenção de autenticidade. Fake news expressam a intenção de enganar, sendo caracterizadas como desinformação, com elementos de falsidade total ou parcial, com o intuito de atingir interesses de grupos ou indivíduos.

Discordamos da classificação de boatos fora do contexto conceitual de fake news. Isso porque boatos apresentam algum nível de intenção de atingir indivíduos ou grupos, bem como quando associados às TICs ganham abrangência capaz de desestabilizar sistemas democráticos e destruir reputações. Concordamos parcialmente com a caracterização de fake news dada por Recuero e Gruzd (2019) como desinformação, porém consideramos que este conceito de fake news ainda é incompleto e optamos, neste trabalho, por adotar a perspectiva conceitual de Wardle e Derakhshan (2017).

Apesar de observarmos e sofrermos com os efeitos perniciosos que a disseminação de fake news causam na sociedade, segundo pesquisadores como Wardle e Derakhshan (2017), ainda estamos na fase inicial da tentativa de entender os impactos que fake news podem causar através de ampla divulgação, via imediatismo, nas redes sociais virtuais. Para Wardle e De- 
rakhshan (2017, p.4), fake news são parte de um panorama mais amplo caracterizado como desordem informacional, a qual está relacionada à "poluição da informação" por conteúdos criados e disseminados através de tecnologias contemporâneas que proporcionam a sua disseminação em larga escala. A disseminação da desordem informacional ocorre através de uma rede de comunicação virtual complexa, voltada para a criação de técnicas de difusão de diversos tipos de conteúdos, os quais são reproduzidos através de inúmeras plataformas que hospedam e reproduzem esses conteúdos informacionais adulterados ou fabricados com propósitos perniciosos.

De acordo com Wardle e Derakhshan (2017, p. 4-5), desde a vitória de Donald Trump nas eleições norte-americanas, em 2016, e das eleições para o Brexit no Reino Unido, as discussões sobre como a desordem informacional influencia Estados democráticos foi intensificada. Além disso, há preocupação crescente sobre como a desordem informacional, em épocas de campanhas eleitorais, podem gerar confusão e desconfiança, elevando a tensão entre diferenças socioculturais ao insuflar nacionalismos, preconceitos étnicos, religiosos, raciais, de gênero etc. No relatório produzido por encomenda do Conselho da Europa em Estrasburgo, em 2017, a desordem informacional é um fenômeno de abrangência mundial que está relacionada à "poluição da informação", tornando o termo fake news insuficiente para expressar a complexidade desse fenômeno. Nesse sentido, Wardle e Derakhshan preferem não utilizar o termo fake news no relatório, preferindo desordem informacional, por dois motivos: 1 - o termo fake news não é suficiente para a complexidade da "poluição da informação" e 2 - devido ao fato de que políticos se apropriaram do termo fake news para usarem a seu bel prazer, acusando organizações de notícias, contrárias aos seus interesses, de manipularem informações. Nesse sentido, diversos políticos pelo mundo afora utilizam o termo fake news para reprimir, limitar e destruir a imprensa livre. Wardle e Derakhshan (2017, p. 5-6) investigam o fenômeno da desordem informacional através da seguinte divisão: três elementos (agente, mensagem e interpretante), três fases (criação, produção e distribuição) e três tipos (misinformation, disinformation e mal-information).

Por ser um panorama amplo de análise, o fenômeno da desordem informacional está fora do escopo deste texto. Sendo assim, optamos por utili- 
zar o termo fake news, caracterizando-o de acordo com Wardle e Derakhshan (2017), refente aos três tipos de desordem informacional, quais sejam:

- Mis-information: quando informações espúrias são criadas e compartilhadas sem a intenção de causar danos.

- Dis-information: quando informações espúrias são conscientemente e deliberamente criadas e compartilhadas a fim de causar danos às pessoas, grupos sociais, organizações ou países.

- Mal-information: quando informações genuínas, isto é, baseadas em fatos, são compartilhadas estrategicamente com objetivos de causar danos, alterando a informação da esfera privada para a pública, prejudicando pessoas, organizações e países.

Como exemplo de mis-information, podemos citar fake news que circulam nas redes sociais, principalmente no YouTube, sobre a suposta propriedade benéfica da planta Aranto para o tratamento do câncer. Segundo Pinheiro (2020), a planta tem sido estudada por pesquisadores, mas ainda não há comprovações que atestam cientificamente o seu uso para o tratamento do câncer.

Para exemplificar a dis-information, podemos citar fake news sobre vacinas veiculadas nas redes sociais, baseadas em negacionismo científico, crenças religiosas e ideologias diversas, as quais são os sustentáculos de teorias da conspiração. Dis-information pode ser canalizada para interesses políticos e usada como ferramenta para confundir as pessoas e prejudicar sistemas democráticos. ${ }^{3}$ Algumas fake news afirmam que vacinas causam autismo, câncer, HIV e até mesmo mortes. Um caso típico de dis-information relacionada às vacinas ocorreu, segundo o site G1 (2019), nas Filipinas,

${ }^{3}$ De acordo com uma pesquisa realizada pelo Centro de Pesquisas e Estudos de Direito Sanitário (CEPEDISA), da Faculdade de Saúde Pública da USP (FSP) e a Conectas Direitos Humanos, o governo federal, comandado pelo presidente Jair Messias Bolsonaro, executou uma estratégia institucional de propagação do coronavírus. A pesquisa colheu dados sobre 3049 normas federais e estaduais, em 2020, atestando discrepâncias entre governo federal e governos estaduais. Segundo Eliane Brum (2021), a pesquisa analisou portarias, medidas provisórias, instruções normativas, decretos, leis, decisões e afirmações feitas em público pelo presidente da república. A pesquisa indica que, contrariamente ao que muitos afirmam, não há incapacidade administrativa do governo federal no que concerne à gestão da pandemia, mas, sim, um desempenho eficaz e uma deliberação favorável à ampla disseminação do Covid-19 no Brasil, com a finalidade de favorecer a política econômica e estratégias de necropoder adotadas pelo governo. A pesquisa intitulada Direitos na Pandemia: Mapeamento e Análise das Normas Jurídicas de Resposta à Covid-19 no Brasil pode ser acessada neste link: https://www.conectas.org/wp/wp-content/uploads/2021/01/Boletim_Direitos-naPandemia ed 10.pdf 
onde uma mulher chamada Arlyn B. Calos perdeu os dois filhos que contraíram sarampo por acreditar em fake news disseminadas via Facebook, as quais afirmavam que vacinas causam mortes.

Podemos citar, também, fake news sobre as vacinas contra o Covid19 disseminadas no Brasil, entre as quais observamos declarações de pastores e do próprio presidente da república, Jair bolsonaro. De acordo com Jucá (2020), em uma celebração religiosa, um pastor teria afirmado que a vacina contra Covid-19 é uma substância que entra no corpo humano e altera o nosso DNA. Outra fake news sobre a vacina contra o Covid-19 foi disseminada pelo presidente Jair Bolsonaro ao afirmar que a vacina transformaria as pessoas em jacaré.

Outros exemplos de dis-information, com finalidade política, são fake news cunhadas para destruírem sistemas democráticos e aniquilar reputações individuais, como no caso das eleições brasileiras, em 2018, bem como nos ataques à ativista ambiental Greta Thunberg. Segundo Ribeiro (2019), Greta sofre ataques nas redes sociais, tendo seu nome associado aos mais variados tipos de informações espúrias. Há casos de dis-information em que a ativista Greta Thunberg, por ter seu cabelo penteado em tranças, é associada às crianças da propaganda nazista. Ou ainda, fake news sobre ela ser neta do bilionário George Soros.

No caso das eleições brasileiras ocorridas em 2018, segundo Avelar (2019), em matéria publicada no Jornal britânico The Guardian, 42\% das mensagens favoráveis à direita eram fake news que favoreciam o então candidado Jair Bolsonaro, do Partido Social Liberal (PSL) e 3\% das mensagens favoráveis à esquerda eram fake news, as quais favoreciam o candidato do Partido dos Trabalhadores (PT), Fernando Haddad.

Por fim, como exemplo de mal-information, podemos citar o caso da divulgação do áudio referente à escuta telefônica entre a ex-presidenta Dilma Rousseff e o ex-presidente Luiz Inácio Lula da Silva, ambos do Partido dos Trabalhadores (PT), sobre o convite feito a ele, por Dilma, para ser ministro da Casa Civil, em 2016. O caso foi retratato pelos principais veículos midiáticos no Brasil como tentativa de evitar a prisão de Lula e travar as investigações da Lava Jato contra ele. Posteriormente o site The Intercept, junto com o jornal Folha de São Paulo, divulgou escutas telefônicas, vazadas 
pelo hacker Walter Delgatti, que colocaram em xeque a operação Lava Jato e todas as acusações contra Lula.

Outro exemplo de mal-information foi o ataque machista sofrido pela cientista Katie Bouman, responsável por divulgar a primeira imagem de um buraco negro na história da ciência. De acordo com a Revista Galileu (2019) e com o site de notícias UOL (2019), Bouman foi alvo de críticas sexistas, as quais afirmavam que ela estava se sobressaindo demais em relação aos outros pesquisadores. Tais críticas originaram fake news sobre a pesquisa, as quais afirmavam que as centenas de milhares de linhas de código do algoritmo que deu origem a captura da imagem, ou seja, 90\% do trabalho, teriam sido feitas pelo colega de Bouman, que desmentiu as fake news.

Fake news atingem amplamente usuários de redes sociais porque são conteúdos informacionais filtrados, pontencializados e direcionados por algoritmos. De acordo com Branco (2017, p. 51-52), nem tudo que os outros postam aparece no nosso news feed, no caso do Facebook. Segundo Pariser (2012, p. 29-30, capítulo 1), em seu livro O filtro invisivel, a solução do Facebook para lidar com a grande quantidade de postagens em sua rede social, logo nos primórdios de sua criação, foi usar o algoritmo EdgeRank que atua por trás da página inicial da plataforma, filtrando conteúdos relevantes. Logo, outras redes sociais e jornais como o The New York Times começaram a usar algoritmos nas suas páginas iniciais. Baseado em três fatores de relevância, o algoritmo filtra as informações e as direciona para os usuários de acordo com a afinidade, o peso relativo da cada conteúdo e o tempo. Assim, temos que:

- Fator de afinidade: é medido pela proximidade que o usuário da rede social, por exemplo, do Facebook, tem com outro usuário através do tempo de interação entre ambos. Quanto mais proximidade eles tiverem, mais atualizações receberão um (a) do outro (a).

- Fator de conteúdo e sua importância para a rede social: é medido através de prioridades conteudísticas. Geralmente conteúdos que indicam informação sobre relacionamentos tem mais prioridade sobre outros.

- Fator tempo: a relevância é dada às postagens mais recentes, as quais têm mais importância do que postagens antigas. 
Segundo Branco (2017, p.52), o Facebook interfere na disponibilização do conteúdo que é mostrado na sua plataforma através de filtros-bolha, que são caracterizados como a personificação do conteúdo da informação relacionada às pegadas digitais que os usuários (as) deixam ao acessarem a rede social. Essa personalização de conteúdo para direcionamento de informação a usuários e grupos de usuários específicos é feita por mecanismos algorítmicos. Nesse sentido, os filtros-bolha aproximam pessoas com ideias semelhantes e afastam aquelas com pensamentos divergentes. A bolha limita a diversidade e aglomera usuários com afinidades ideológicas. Isso vai diretamente contra os princípios básicos do sistema democrático que se fundamenta justamente na interação entre opiniões divergentes e na convivência livre e respeitosa entre pessoas com pontos de vista diferentes.

Através de filtros-bolha, fake news, principalmente aquelas de cunho político, são direcionadas para grupos específicos e amplamente disseminadas em plataformas sociais como Facebook. Em nota recente, datada de 9 de janeiro de 2020, o Facebook anunciou que não faria mudanças que pudessem alterar significativamente as suas regras de publicidade política. Nesse sentido, a disseminação de fake news tem a tendência de aumentar em anúncios que se circunscrevem no cenário político. Segundo Katie Harbath, chefe de política global de eleições do Facebook, a posição da empresa está condizente com a liberdade de expressão, no respeito aos processos democráticos e por acreditarem que em democracias maduras e com imprensa livre, o discurso político já se expressa de forma extremamente minuciosa. Com a decisão do Facebook, diferentemente de outras redes sociais, como Twitter e Spotify, as quais proibiram propagandas com conteúdo político nas suas plataformas, campamhas políticas que utilizam a rede social para dissseminarem fake news continuarão a utilizarem a plataforma para direcionarem conteúdos espúrios, sem que a rede social virtual de Mark Zuckerberg tenha nenhuma responsabilidade em relação aos conteúdos divulgados. (RIBEIRO, 2020).

Os impactos das redes sociais para indivíduos, grupos, organizações e sistemas democráticos é amplamente discutido por especialistas. De acordo com matéria publicada no Jornal El País Brasil, por Rebeca Gimeno, no dia 13 de fevereiro de 2019, não há um consenso sobre os malefícios e su- 
postos benefícios dos impactos do uso das redes sociais virtuais. Entretanto, pesquisas recentes mostram que diminuir ou deixar de usar totalmente as redes sociais, como o Facebook, reduz sentimentos relacionados à depressão e à ansiedade, melhorando o bem-estar dos indivíduos. A pesquisa realizada pela New York University e pela Stanford University utilizou o mesmo método usado por laboratórios farmacêuticos para testar a eficácia de remédios. Os participantes da pesquisa, usuários do Facebook, foram divididos em dois grupos: um grupo permaneceu conectado ao Facebook e o outro ficou desconectado durante a realização da pesquisa. O grupo que ficou desconectado teve melhoras siginificativas no seu bem-estar, na medida em que se sentiam mais felizes, mais satisfeitos com as próprias vidas e, consequentemente, menos depressivos e ansiosos. Ainda, o grupo que permaneceu desconectado do Facebook, o dos usuários abstêmios, apresentou queda na polarização e divisão de opiniões geradas por questões relacionadas à política. Alinhado a essa queda, houve o aumento da capacidade de entender opiniões diferentes. Esse impacto de queda na polarização é observado na comparação entre os dados relativos aos anos de 2006 a 2016, nos quais o nível de polarização na sociedade norte-americana aumentou 100\%. O grupo que ficou ausente do Facebook para a realização da pesquisa diminiu em $42 \%$ esse indicador de polarização.

A decisão de deixar de usar redes sociais, como Facebook, pode proporcionar um encontro com nós mesmos e a reproximação presencial com outras pessoas por um período de tempo maior. Esse encontro com nós mesmos é a condição de solitude que, segundo Bauman (2011), é necessária para que possamos exercitar nossa reflexão sobre assuntos e acontecimentos diversos, soltar nossa imaginação, apreciar detalhes do mundo que ficam escondidos quando somos sugados pelas telas dos nossos smartphones. A fuga da solidão, via redes sociais virtuais, amplia ainda mais a solidão, impedindo a prática de nossa solitude. Entendemos que a inibição da solitude restringe e impede o despertar do pensamento crítico, proporcionando um caminho amplo para a colonialidade de mentes através da disseminação de fake news.

Em seu livro Cartas do mundo líquido moderno, no capítulo intitulado Sozinhos no meio da multidão, Bauman (2011) menciona uma matéria 
que foi publicada no jornal Chronicle of Higher Education, em que relata a história de uma adolescente que havia enviado três mil mensagens de texto em um único mês. Mais precisamente isso indica que a adolescente enviou aproximadamente uma mensagem a cada dez minutos. Nesse período em que esta adolescente esteve conectada às redes sociais virtuais, através das tecnologias digitais, ela nunca esteve só por mais de dez minutos. Assim como milhares de outras pessoas que fazem uso desmedido das tecnologias digitais, ela não teve a oportunidade de estar consigo mesma, imersa em seus pensamentos, vislumbrando o possível futuro, sonhando acordada, refletindo. Como destaca Bauman (2011, p.9):

Assim, a adolescente nunca ficou sozinha por mais de dez minutos; nunca ficou só consigo mesma, com seus pensamentos, seus sonhos, seus medos e esperanças. A essa altura, ela deve ter se esquecido de como uma pessoa vive, pensa, faz coisas, ri ou chora na companhia de si mesma, sem a presença de outros. Melhor dizendo, ela nunca teve a oportunidade de aprender essa arte. O fato é que somente em sua incapacidade de praticar essa arte é que ela não está sozinha.

O medo e a aversão à solidão faz com que as pessoas busquem alternativas para preencher o vácuo deixado pela ausência de companhia. A tecnologia trouxe consigo a internet e surgiu como um alívio para o despreparo em lidar com a solidão e para o medo de estar só. Segundo Bauman (2011, p. 9-10), as tecnologias vieram apenas suprir necessidades das quais elas não criaram, mas apenas tornaram explícitas através de um único apertar de uma tecla ou de alguns toques nas telas. Nesse contexto, quanto mais as pessoas fazem uso das tecnologias, mais adentram ao vazio devido à ausência de companhia e deixam de usar seu corpo, seus músculos, seus pesamentos e sua imaginação. As redes sociais virtuais surgidas a partir do advento da internet substituíram a porta de madeira, que possibilitava sair pelo mundo à procura de companhia quando a solidão era impossível de suportar, pelas telas dos aparelhos digitais, através dos quais num simples toque as portas das redes sociais como o Facebook, Twitter e WhatsApp se abrem com centenas, milhares de contatos online. Assim, nunca mais estivemos sós; os contatos podem ser feitos e desfeitos com apenas um ou dois toques na tela do celular. Situações indesejadas podem ser evitadas, o medo da solidão é ilusoriamente dissipado, os compromissos e comprometimentos se tornam 
superficiais. Como ressalta Bauman (2010, p.19): "O contato face a face é substituído pelo contato tela a tela dos monitores; as superficies é que entram em contato. [...] O que se perde é a intimidade, a profundidade e durabilidade da relação e dos laços humanos."

Para Bauman (2011, p. 11), estar sempre conectado indica que nunca estamos sós. Para fugir da solidão o ser humano deixa escapar a chance de estar consigo mesmo, de estar em solitude. As consequências desastrosas da ausência de solitude é que não conseguimos sentir o prazer de apreciar uma noite estrelada ou ler calmamente um livro; não conseguimos refletir, ponderar sobre nossos próprios pensamentos e, assim, não conseguimos prover de conteúdo e dar sentido à comunicação.

Os termos solidão e solitude tem significados diferentes e expressam condições psicológicas e situações distintas. Solidão, segundo o Dicionário Michaelis online, é o estado ou condição da pessoa que está em isolamento ou se sente só. Solidão também é considerada uma condição de sofrimento de quem foi privado involuntáriamente da companhia de outros. De acordo com o Dicio - Diconário Online de Português, solitude é uma condição de interiorização, de introspecção de quem prefere se isolar propositadamente para o exercício da reflexão. Podemos considerar que é um modo prazeiroso de estar consigo mesmo por algum tempo. Como afirma Paul Tillich (1963, p. 9, capítulo 1): "Nossa linguagem detectou sabiamente esses dois lados do ser humano estar só. Ela criou a palavra "solidão" para expressar a dor de estar só. E criou a palavra "solitude" para expressar a glória de estar só."

Consideramos que a ausência da condição de solitude, ampliada pelo uso das tecnologias digitais, a qual Bauman se refere, propicia a absorção de informação de modo acrítico. Essa informação também pode ser disseminada na forma de fake news (mis-information, dis-information e malinformation), colonializando mentes, manipulando a opiniçao pública e direcionando ações.

\footnotetext{
${ }^{4}$ Our language has wisely sensed these two sides of man's being alone. It has created the word "loneliness" to express the pain of being alone. And it has created the word "solitude" to express the glory of being alone. (TILLICH, 1963, p. 9, capítulo 1).
} 


\section{Colonialidade e decolonialidade de mentes: os impactos de fake news}

$A$ colonialidade de mentes é um dos aspectos mais danosos da subjugação de povos pelos colonizadores. A posse e o controle dos corpos e das mentes das vítimas dessas formas de subjugação permanece até hoje em suas versões contemporâneas, trazendo consigo os rastros de ações e intenções do passado, isto é, dominar para escravizar a fim de manter sob controle e extorquir tudo o que for pertinente aos interesses do colonizador. Em uma de suas versões contemporâneas, a colonialidade de mentes usa como ferramentas as novas tecnologias da informação (TICs), através do colonialismo digital, principalmente via redes sociais virtuais, as quais são aparatos de disseminação de fake news.

A colonialidade de mentes, segundo Dascal (2009, p. 2), é um tipo de violência epistêmica caracterizada como transmissão e modificação de sistemas sociais e de hábitos de pensamentos, tais como família, linguagem, religião, ciência, educação, ideologia, mídia e agrupamentos políticos, os quais disseminam formas de imposição do pensamento e ação do colonizador. A metáfora colonialidade de mentes, usada para indicar o domínio de povos e de seu sistema de pensamento por outros povos, expressa as seguintes características, as quais não estão restritas à situações sócio-políticas classificadas como "coloniais", mas abrangem uma variedade de processos mentais indicativos de colonialidade:

- Intervenção do colonializador, caracterizado como uma fonte externa, no âmbito mental de um indivíduo ou grupos de indivíduos, os quais são definidos como colonializados.

- A intervenção do colonializador afeta aspectos centrais do contéudo, modo de funcionamento e estrutura da mente dos colonializados.

- Os efeitos da colonialidade de mentes são duradouros e não são facilmente removíveis.

- Há um grande desequilíbrio de poder entre as partes envolvidas - colonializador e colonializados.

- Colonializador e colonializados podem estar conscientes ou serem inconscientes dos seus papéis. 
- Ambos, colonializador e colonializados, podem participar do processo de colonialidade de mentes voluntariamente ou involuntariamente.

Como exemplo de colonializadores e colonializados inconscientes de seus papéis, Dascal (2009, p.2-4, para. 5-10) cita o exemplo dado pelo educador brasileiro Paulo Freire, o qual caracteriza o sistema educacional como colonializador de mentes pautado no "modelo bancário". Isso porque o conhecimento é considerado uma commodity que é depositado, por aqueles que o detêm, no caso os professores, na mente de quem não possui o conhecimento, no caso os alunos que recebem passivamente o conhecimento. Aos professores é dada a condição de autoridade epistêmica, assim como em outros domínios da sociedade é designada outras autoridades epistêmicas como religiosos, cientistas, família etc. Na maioria dos casos, os colonializadores não percebem que também tiveram suas mentes colonializadas e que estão colonializando mentes, tampouco os colonializados percebem que estão sendo subjugados por colonializadores via autoridade epistêmica. Ambos não percebem os danos da imposição de crenças e padrões de ações porque acreditam que estão colaborando para o bem comum da sociedade.

Outro exemplo seria o de desiquilíbrio de poder entre colonializador e colonializado e seus efeitos duradouros, nos quais os colonializados não estão cientes de sua colonialização, expresso na contemporaneidade, por exemplo, pela relação entre redes sociais (empresas como Facebook) e seus usuários. As plataformas digitais, como diria Bauman (2011, p. 15, capítulo On-line, off-line), roubam o contato com o olhar e a proximidade física, transformando o contato presencial em não convidativo, em perda de tempo. A tela, janela para a virtualidade, estabelece relações virtuais nas quais não há o desejo de mergulhar na profundidade do sentido das coisas. Mergulhos profundos não fazem parte da superficialidade das relações tecidas na virtualidade. Como afirma Bauman (2011, p, 15, capítulo On-line, off-line):

Numa vida de contínuas emergências, as relações virtuais derrotam facilmente a "vida real". Embora os principais estímulos para que os jovens estejam sempre em movimento provenham do mundo off-line, esses estímulos seriam inúteis sem a capacidade dos equipamentos eletrônicos de multiplicar encontros entre indivíduos, tornando-os breves, superficiais e sobretudo descartáveis. As rela- 
ções virtuais contam com teclas de "excluir" e "remover spams" que protegem contra as consequências inconvenientes (e principalmente consumidoras de tempo) da interação mais profunda.

No mundo off-line, os contatos são menores, em comparação com quantidade exorbitante de amizades virtuais, isso porque os laços são aprofundados e os vínculos fortalecidos, prezando pela qualidade e não pela quantidade. Diferentemente dos laços e compromissos tecidos na virtualidade, que são instantâneos, as relações presenciais são estabelecidas na intenção de serem permanentes. (BAUMAN, 2011). A imediaticidade e o enfraquecimento dos laços entre os usuários das redes sociais virtuais aumenta a sua condição de solidão e isolamento, em detrimento da solitude, propiciando campo fértil para a colonialidade de mentes, via fake news, dado que o pensamento crítico também se esvai junto com a desistência em mergulhar no sentido profundo das coisas. A mídia é designada a ser a autoridade epistêmica, neste caso, a rede social virtual como ferramenta propiciadora de veiculação de fake news.

A autoridade epistêmica como ferramenta de colonialidade recebe o apoio de estruturas que a transforma em autoridade social para ser melhor aplicada. Essa transformação pode ser feita por meio de demonstração simbólica de autoridade a fim de desvalorizar outros, ou por meio de diversos tipos de discriminações, através do uso da violência coercitiva ou por meio de recompensas e punições socioeconômicas. A autoridade social é ineficaz sem o suporte da autoridade epistêmica para garantir o sucesso da implementação da colonialidade de mentes. A colonialidade de mentes efetivamente ocorre quando o colonializado adota os princípios epistêmicos do colonializador em seu modo assimétrico de diferenciação entre dominador e dominado, superior e inferior. (DASCAL, 2009, p. 4).

Para Dascal (2009, p. 5-6; 26), as reações à colonialidade de mentes vem com o movimento de decolonialização que engloba, entre outras, dois tipos de ações: rejeição e resistência. Neste texto, optamos por utilizar o termo decolonializar visto que a concepção de decolonialização de mentes se aproxima da concepção de decolonizar usada por Walsh (2009). Não há um consenso entre pesquisadores sobre o uso dos termos decolonizar e descolonizar. Alguns os usam para expressarem significados diferentes e outros os 
usam como sinônimos. Entre os que defendem a diferença dos conceitos, como Walsh (2009), decolonizar não é simplesmente um desarmar, desfazer ou reverter o colonial, pois isso significaria apenas mudar do colonial para o não colonial, excluindo os padrões e traços da colonialidade, o que não ocorre, de fato. Decolonizar, portanto, é um conceito que marca posicionamentos e atitudes que se expressam em ações contínuas que marcam a luta contra a dominação e controle espistêmico, de subjetividades e de existências que se refletem na opressão de gênero, sexualidade, étnico-raciais, classe social, geracional etc. Desse modo, a decolonização é uma contraposição a colonialidade e a descolonização é uma contraposição ao colonialismo. Colonialismo é entendido como domínio político, geográfico, econômico e cultural dos conquistadores sobre os conquistados e colonialidade é a continuidade da dominação e opressão do poder dos colonizadores em relação aos colonizados, mesmo após a independência política e emergência de Estados-Nação. (SANTOS, 2018).

Não entraremos em discussão mais aprofundanda sobre as diferenças entre os termos decolonizar e descolonizar, o que poderá ser assunto de trabalhos posteriores. Escolhemos utilizar o termo decolonializar devido a que, concordamos que há diferenças entre descolonizar um espaço geográfico e decolonizar subjetividades, o primeiro não está necessariamente atrelado ao segundo. Entretanto, por questões de terminologia, usamos, neste texto, os termos colonialidade, decolonialidade e decolonialização porque ambos estão de acordo com o que Dascal e Walsh propõem. Como veremos, com a emergência das TICs, há um novo tipo de colonização, a colonização digital que, de acordo com Kwet (2021), envolve o domínio de espaços virtuais para subjugar política, econômica e socialmente um espaço geográfico, seja ele algum tipo de território ou um Estado-nação. Consideramos que para haver o processo decolonialização de mentes, é imprescindível que os espaços virtuais sejam descolonizados.

Apesar da perspectiva marxista e libertarianista afirmar que somente a revolução livra os colonizados, Dascal afirma que, de acordo com a concepção de Memmi (2006), estes ainda carregam marcas e "lições" assimilados dos colonizadores, o que induz os colonizados a lutarem, carregando, muitas vezes, técnicas de pensamento e métodos de combates similares aos 
dos colonizadores. Nesse sentido, os rastros maléficos do sistema colonialista não desaparecem com a descolonização, mas persistem através do uso da força, da corrupção, da restrição intelectual, perseguição de minorias, violência contra a mulher etc. Para Dascal, tanto o combate intelectual quanto o prático, baseado na luta efetiva, como o proposto por Frantz Fanon, por exemplo, na sua luta contra a colonialidade de mentes na África, carregam padrões de pensamento endossados pela autoridade epistêmica que servem de modelo para colonialidade de mentes. A transmissão de crenças, padrões de pensamento e comportamento, ideologias etc são peças que constituem a identidade e cultura de uma comunidade ou sociedade.

Nesse contexto, Dascal (2009, p. 16, para. 39-40) questiona se pode haver a total decolonialização de mentes, o que seria a estratégia da rejeição radical, desqualificando totalmente a visão de mundo do colonializador. Três pontos principais direcionam a estratégia de rejeição radical:

- Se qualquer valor mínimo referente ao sistema de pensamento do colonializador for aceito pelo colonializado no processo de decolonialização, isso levará a colonialidade parcial da mente que se estenderia a outros, possibilitando a colaboração com o colonializador, provocando a corrupção na luta contra a colonialidade de mentes.

- A eliminação de qualquer marca de colonialidade de mentes é necessária para recuperar as tradições originais que foram substituídas pelos colonializadores. Para recuperar as suas tradições e sua visão de mundo, o colonializado precisa se livrar de crenças, desejos, medos e hábitos mentais incorporados ao seu sistema de pensamentos através do contato contínuo com o colonializador.

- O sistema conceitual do colonizador precisa ser demolido para suprimir a sua autoridade epistêmica.

Dascal (2009) questiona se depois que for realizada a decolonialidade de mentes de modelos externos vindos dos colonializadores, a estratégia daqueles que defendem modos específicos de decolonialização, como o defendido por Fanon, iria impor a sociedade decolonializada outros contéudos passíveis de recolonialidade de mentes, de outros modos. É óbvio que a decolonialização de mentes visa negar a autoridade epistêmica imposta aos povos oprimidos, devolvendo a estes sua autonomia epistêmica através do 
combate ao colonializador. Não se trata de criticar a luta pela decolonialização de mentes, mas apenas questionar até onde a decolonialização também poderia abrir espaço para novas formas de colonialidade de mentes, sendo ela mesma a protagonista neste processo de colonialidade.

Dascal $(2009$, p. 22-23, para. 53;56) propõe um modo de viver com um tipo de colonialidade de mentes, já que para ele a erradicação total não é possível, no qual significaria não ser dominado e nem perder a total autonomia. Ele parte da proposta de decolonialização mista ao invés de modelos radicais puristas, para as quais decolonializar significa recolocar o esquema de colonialidade mental anti-colonial, autêntico e nativo da comunidade, recolonializando-a, apesar de ter um esquema de autoridade diferente do colonializador externo. Esse tipo de recolonialidade de mentes é um processo passivo como o caso da relação professor-estudante, criticada por Paulo Freire. Dascal afirma que, contrariamente a este processo passivo, o processo de reestruturação (re-framing) é ativo, no qual os participantes atuam para construir um novo modelo de esquema mental ao invés de receber passivamente esquemas mentais prontos. Nesse modelo, elementos de diferentes sistemas que são conflitantes se misturam parcialmente para gerar novas alternativas para resolver conflitos. Isso não implica a total aceitação e, tampouco, a total rejeição dos sistemas em conflito. O estabelecimento dessa linha de comunicação entre os sistemas de pensamento possibilita a condição do próprio pensamento.

Seguindo a posição de Dascal sobre a mistura de sistemas conflitantes, não implicando a rejeição e nem a aceitação total do colonializador, analisamos se seria possível aceitar parcialmente a influência das tecnologias digitais enquanto ferramentas de colonialidade de mentes através de mídias sociais virtuais como Facebook, Twitter, WhatsApp, You Tube etc, as quais veiculam sistemas de pensamentos dos colonializadores, podendo estes serem expressos através de fake news.

Consideramos que fake news carregam crenças ancoradas na relação colonializador/colonializado como forma de subjugação de indivíduos ou grupos sociais a interesses de determinado grupo dominante. Fake news, principalmente as de cunho político, veiculadas nas redes sociais virtuais, as quais transmitem informações relacionadas aos interesses do pensamento do 
colonializador, expressam a tentativa de perpetuação de poder do colonializador e a subjugação de colonializados através de uma representação propositadamente irreal do mundo. Um exemplo dessa subjugação é o Facebook que, como apontamos, anunciou que não fará mudanças significativas nas regras de publicidade política, deixando o espaço aberto para veiculação de fake news, principalmente em épocas de eleições. Se por um lado, o Facebo$o k$ pode abrir espaço para maior representatividade de grupos de minorias políticas, por outro lado, serve como ferramenta para divulgação de fake news que são usadas na perpetuação de aspectos nocivos à sociedade como a alienação, o ódio ao diferente, aos economicamente mais pobres e o ódio à política, consolidando o poder de grupos dominantes em relação a grupos dominados.

Se levarmos em conta as características da colonialidade de mentes proposta por Dascal (2009), podemos considerar que, no que concerne às fake news: elas podem ser criadas por colonializadores que atuam como fontes externas aos colonializados, impactados pelas fake news políticas. Enquanto fontes externas, os colonializadores e criadores de fake news atuam disseminando informações espúrias a fim de alterar a estrutura e o funcionamento do pensamento dos colonializados. Isso se configura no desequilíbrio de poder entre disseminadores de fake news, com propósitos indignos, e os impactados pela informação, cuja verdade fica ausente ou em segundo plano. Os criadores de fake news políticas são colonializadores conscientes de seus papéis, porém, os colonializados podem ser conscientes ou inconscientes de seus papéis. Nesse sentido, ambos, colonializador e colonializados participam voluntariamente ou involuntariamente do processo de colonialidade de mentes. Consideramos que, assim como em outros âmbitos da colonialidade de mentes, os efeitos desta, via fake news, são duradouros e devastadores para a emergência e manutenção de democracias.

O discurso constituído por fake news cria e alimenta crenças alienantes que minam a percepção das relações sociais e da realidade, alcançando uma imensa quantidade de pessoas já que, segundo pesquisas, a grande maioria dos usuários do Facebook e whatsApp (comprado pelo Facebook, em 2014) leem notícias através da timeline do facebook e pelo WhatsApp. Segundo Valente (2018), apesar do relatório sobre notícias digitais do Instituto 
Reuters ter divulgado pesquisa sobre os hábitos de consumo do jornalismo, em 2018, apontando o decréscimo do número de pessoas que leem notícias através de redes sociais, em alguns países como Estados Unidos, Reino Unido e França, o Facebook ainda lidera o ranking das redes sociais mais usadas para acessar notícias. O número de acesso de pessoas que leem notícias pelo WhatsApp teve aumento considerável. No Brasil, o Facebook é a rede social mais popular e acessada enquanto fonte de notícias. De acordo com Matos (2018), pesquisa realizada pelo Datafolha, em 2018, mostra que 35\% dos brasileiros entrevistados se informam sobre notícias via WhatsApp e $40 \%$ dos entrevistados utilizam o Facebook para lerem notícias. $62 \%$ dos brasileiros entrevistados usam o WhatsApp e 55\% o Facebook. Em nova pesquisa realizada pela FGV-Dapp em parceria com o G1 sobre debates políticos e circulação de informações em plataformas digitais, realizou-se um levantamento de informações sobre o que foi postado sobre política entre agosto e outubro de 2019 em grupos no WhatsApp. O You Tube, via WhatsApp, foi o site mais compartilhado contendo fake news. 20\% dos 100 links mais compartilhados do You Tube, no WhatsApp, remetiam a fake news. (PAIVA; LAVADO, 2020).

Nesse sentido, além de tentar entender as crenças infundadas, indicativas de fake news, compartilhadas na redes sociais, também precisamos entender as crenças de quem compartilha, bem como as crenças de quem possibilita as ferramentas para este compartilhamento de informação espúria, filtrada por algoritmos programados para fisgar nossas pegadas digitais. Como ressalta Pariser (2011, p. 18, Introdução):

Precisamos entender aquilo em que acreditam os programadores do Google e do Facebook. Precisamos entender as forças econômicas e sociais que movem a personalização, algumas delas inevitáveis, outras não. E precisamos entender o que tudo isso representa para nossa política, nossa cultura e nosso futuro.

Segundo Ethel Rudnitzki (2019), era previsível que a internet não tornaria o ser humano mais informatizado e politizado, mas nos tornamos mais radicalizados e consumidores assíduos de conteúdos apelativos e sensacionalistas, veiculados nas mídias sociais virtuais. A argumentação coerente se transformou em xingamentos vociferados nas redes sociais, num ambiente de radicalização e restrição de opiniões divergentes. Em uma en- 
trevista concedida a Rudnitzki, da Pública, em 2019, Jamie Bartlett afirma que fomos ingênuos ao acreditarmos que tornar a informação mais disponível, permitindo criá-la e compartilhá-la, transformaria o ambiente em um lugar mais politizado, informado e racional. Para ele, essa visão advém do pensamento extremamente liberal e alienado das questões reais do mundo. Para os defensores dessas ideias extremamente liberais, a internet e as redes sociais seriam totalmente livres sem a interferência e controle da informação. A quantidade de informação exorbitante veiculada nas redes sociais, as quais os usuários estão diariamente expostos, como as fake news, são prejudiciais pois a enorme quantidade de informação faz com que usuários comecem a duvidar da veracidade de tudo o que leem. Como forma de amenizar os impactos da internet e redes sociais na sociedade, Bartlett propõe a criação de departamentos que fiscalizem a atuação dos algoritmos, o impedimento da compra de empresas de comunicação menores por empresas maiores (oligopólios) e a inserção de temas como fake news na educação.

Para Mariconda (2019), o despotismo tecnológico advindo da evolução tecnológica, como o surgimento das TICs, deu origem ao estado de exceção tecnológica que é caracterizado pela ausência e supressão de normas, leis e regulações para o uso de tecnologias, bem como pela instauração e imposição de um Estado onde prevalece o direito do mais forte (corporações transnacionais, grandes companhias, etc). Nesse estado de exceção tecnológica, há a prática contínua da violência contra cidadãos e consumidores dessas novas tecnologias, retirando-lhes a proteção legal de seus direitos em detrimento dos interesses dos detentores do poder econômico.

Entendemos que esse estado de exceção tecnológica é oriundo de uma nova forma de colonialismo, surgida com as TICs, o colonialismo digital realizado pelas Big Techs (corporações transnacionais de tecnologias). Segundo Kwet (2021), o colonialismo digital é o uso, pelos poderes dominantes (colonizadores), das propriedades de infraestruturas digitais, do conhecimento, do controle dos meios de computação (software, hardware e conectividade da rede) para manter o Sul do planeta em uma situação de permanente dependência. Esse uso de infraestruturas digitais e dos meios de computação pode ser observado em plataformas como Google e Facebook, as quais extraem dados dos usuários que podem ser usados para fins diver- 
sos que atendem desde interesses econômicos imperialistas de empresas a interesses políticos, impactando, por exemplo, em eleições, através da disseminação de fake news, prejudicando sistemas de governo democráticos. Como Kwet (2021) aponta: "Nas últimas décadas, as corporações transnacionais de "Big Tech" sediadas nos Estados Unidos acumularam trilhões de dólares e ganharam poderes excessivos para controlar tudo, desde negócios e trabalho até mídia social e entretenimento no Sul Global. O colonialismo digital está agora engolfando o mundo." ${ }^{\circ}$

Consideramos que é nesse estado de exceção tecnológica, oriundo do colonialismo digital, que a disseminação de fake news encontra respaldo. A colonialidade de mentes, possibilitada pela interação contínua e desregrada com as plataformas virtuais, é uma ferramenta de manipulação sócio-econômica-cultural. A não regulamentação das TICs faz com que plataformas digitais, como o Facebook, permitam a circulação de fake news, principalmente de cunho político, influenciando e alterando resultados de eleições e minando Estados democráticos. A proposta de Dascal sobre a mistura de modelos conflitantes de colonialidade de mentes, a fím de possibilitar o próprio pensamento, é minada, nestas plataformas, através das bolhas virtuais onde há interações entre semelhantes e por onde circulam informações homogêneas. O paradigma da complexidade, através de uma ética pensada via princípios hologramático e dialógico, pode jogar luz no problema das bolhas virtuais e oferecer um caminho para amenizar os impactos negativos do uso da internet e das mídias sociais na sociedade, proporcionando subsídios para o processo de decolonialização de mentes.

\section{4. Ética da Complexidade: repensando o problema da colonialidade de mentes}

A ética da complexidade é oriunda do paradigma da complexidade, o qual adota a perspectiva sistêmica, a partir da relação de reciprocidade e emergência das partes com o todo, enquanto formação não linear de padrões, baseado no princípio hologramático. O paradigma da complexidade

\footnotetext{
${ }^{5}$ Over the past decades, transnational "Big Tech" corporations based in the United States have amassed trillions of dollars and gained excessive powers to control everything, from business and labor to social media and entertainment in the Global South. Digital colonialism is now engulfing the world. (KWET, 2021).
} 
vai, portanto, de encontro ao pensamento mecanicista que tem como bases conceituais o determinismo, o reducionismo, a analiticidade e o dualismo que fragmentam o agente do seu ambiente. O pensamento baseado na perspectiva mecanicista de mundo tem como um de seus principais fundamentos o método cartesiano, resumidamente, expresso por Morin (2003, p. 87-88): dividir cada um dos problemas em tantas partes quanto seja possível para melhor maneira de resolvê-los e ordenar os pensamentos a partir dos mais simples e fáceis de obter conhecimento para, paulatinamente, alcançar o conhecimento complexo. Esses dois fundamentos do método cartesiano englobam os princípios reducionista e o de separação que regem e orientam o pensamento científico.

Para Morin (2005, p.183), diferentemente da concepção mecanicista cartesiana, entender a complexidade que envolve as formas de vida não está relacionado à separação, ao isolamento e às demarcações precisas das partes em relação ao todo. Isso porque de acordo com o princípio hologramático, as partes estão no todo, assim como o todo está nas partes. Em outras palavras, um sistema pode ser considerado mais e menos do que a soma de suas partes na medida em que: enquanto todo, ele pode ser caracterizado como mais do que a soma de suas partes, dado que existem propriedades emergentes que se formam a partir da interação entre as partes. O todo é considerado também menos do que a soma de suas partes, visto que algumas propriedades são inibidas pela relação das partes com o todo. O todo é mais do que o todo devido a que ele retroage sobre as partes, que por sua vez, retroagem sobre o todo. Segundo Morin (2003, p. 88), o conhecimento do todo depende do conhecimento das partes e o conhecimento das partes depende do conhecimento do todo. Assim, ao invés de isolar, mutilando cada uma das dimensões dos fenômenos, é necessário investigá-los a partir de suas multidimensionalidades. A complexidade, nas palavras de Morin (1977, p. 344), é caracterizada como:

A complexidade impõe-se, em primeiro lugar, como impossibilidade de simplificar; surge onde a unidade complexa produz as suas emergências, onde se perdem as distinções e clarezas nas identidades e causalidades, onde as desordens e as incertezas perturbam os 
fenómenos, onde o sujeito-observador surpreende o seu próprio rosto no objecto da sua observação, onde as antinomias fazem divagar o curso do raciocinio.

De acordo com Morin (2003, p. 89), é preciso substituir o pensamento isolacionista que fragmenta as partes do todo por um pensamento que diferencia e une. Há a necessidade de substituir um pensamento que separa e reduz por um pensamento do complexo, respeitando diferenças ao mesmo tempo que reconhece a unicidade, tratando as diversas realidades como solidárias e conflituosas, assim como sistemas democráticos que alimentam e regulam antagonismos. Nas palavras de Morin (2003, p, 89): “É preciso substituir um pensamento que isola e separa por um pensamento que distingue e une. É preciso substituir um pensamento disjuntivo e redutor por um pensamento do complexo, no sentido originário do termo complexus: o que é tecido junto." Morin (2003, p. 93-97) concebe sete diretrizes complementares e interdependentes para o pensamento complexo, dentre as quais, para os propósitos deste artigo, destacamos três:

- Princípio hologramático - a parte está no todo assim como o todo está em cada parte do sistema.

- Princípio do circuito retroativo - introduzido por Norbert Wiener, permite o conhecimento de processos auto-reguladores, pautados no feedback negativo que reduz o desvio e estabiliza o sistema, bem como no feedback positivo, o qual funciona como um mecanismo amplificador. Essa amplificação pode ser pensanda nos casos de violência cometida por um indivíduo que pode gerar uma reação violenta que, por sua vez, poderá ocasionar uma relação bem mais violenta que as anteriores. Feedbacks inflacionários ou estabilizadores são observados em contextos sociais, econômicos, políticos, psicológicos etc.

- Princípio dialógico - une dois princípios antagônicos que são considerados excludentes para constituir o fenômeno complexo.

Para Morin (2003), contrariamente a perspectiva fragmentada na qual os âmbitos psicológicos, sociais, culturais, econômicos e políticos são investigados separadamente, os princípios do pensamento complexo os colocam numa realidade multidimensional e interligada. Nessa realidade, os fenômenos são considerados sistêmicos, isto é, um conjunto organizado e 
auto-organizado de partes diferentes que possibilitam a emergência de qualidades que não existiriam nas partes isoladas umas das outras. Por exemplo, indivíduos formam uma sociedade que possibilitará emergências sociais como a língua e a cultura. A concepção dialógica de união dos antagônicos, mas que ao mesmo tempo são complementares, também pode ser rastreada desde a antiguidade nos princípios opostos do yin e yang no pensamento chinês, passando pelo pensamento grego com Heráclito em sua associação de termos contraditórios, na idade clássica com Pascal e sua noção do todo e as partes, no período da modernidade com Kant através da evidência dos limites da razão, na incerteza de Nietzsche, na dialética marxista e no metamarxismo de Adorno e Horkheimer. Todos criticaram a racionalidade predominante em suas épocas, fornecendo elementos para a elaboração da concepção de pensamento complexo, o qual é expresso através das obras de IlyaPrigogine, Norbert Wiener, Henri Atlan, Thomas Khun, von Foerster, Humberto Maturana, Francisco Varela, David Bhom etc.

O pensamento complexo é útil para tratar de problemas organizacionais, sociais e políticos, possibilitando estratégias para lidar com as incertezas, oferecendo clarificações para dificuldades existenciais através da comprensão, bem como para a elaboração de uma ética da solidariedade. (MORIN, 2003). Essa ética, segundo Morin (2005), é denominada antropoética na medida em que, apesar dos problemas relacionados à moral e à ética serem diferentes nas mais variadas culturas e sociedades, há um aspecto social, individual e genérico da espécie humana que estão ligados. Esse aspecto expressa que o ser humano precisa desenvolver a sua autonomia pessoal e as suas responsabilidades pessoais, desenvolver participação social e responsabilidades sociais, dado que compartilhamos destinos comuns. O lado social da antropoética está intrinsecamente ligado à democracia porque é em sistemas democráticos que supostamente deve existir a relação de solidariedade e responsabilidade entre indivíduos e sociedade. A democracia exerce o controle em princípio e o controlado passa a controlar quem controlava, exercendo suas responsabilidades através das eleições. Como ressalta Morin (Os sete saberes necessários à educação do futuro, p.11): 
Evidentemente, não existe democracia absoluta, ela é sempre incompleta, mas sabemos que vivemos em uma época de regressão democrática porque existe, cada vez mais, o poder tecnológico que agrava os problemas econômicos, mas na verdade, é importante orientar e guiar essa tomada de consciência social que leva à cidadania para que o indivíduo exerça sua responsabilidade.

É através do pensamento complexo que percebemos a realidade como todo, isto é, o todo é a realidade. A fragmentação do pensamento faz com que percebamos erroneamente que a realidade é dividida em partes isoladas que se unem para formar um todo não sistêmico. A visão que exprime a inseparabilidade entre as partes que formam o todo também pode ser observada nos trabalhos elaborados por David Bohm; para ele (1996) a maneira como nós vemos e percebemos o mundo é direcionada pelo nosso pensamento que é incompleto e fragmentado. Essa fragmentação, como ressaltamos, é moldada pela visão mecanicista que reduz o mundo a elementos básicos, os quais são externos e independentes uns dos outros. As partes estão dissociadas do contexto e, por isso, desenvolvem-se separadamente e não como constituintes de um todo organizado. Para ele, as partes são dependentes do contexto, estando internamente conectadas com o todo; qualquer alteração em uma das partes implica em mudança no todo.

De acordo com Bhom (2005, p. 20), a fragmentação é uma tentativa de estender a análise do mundo em partes separadas, dividindo o que não é divisível. A tentativa de dividir em partes gera outra tentativa, a de unir o que não tem relação de união. Isso pode ser percebido em grupos políticos, econômicos, religiosos etc nos quais há um senso de divisão e separação dos membros desses grupos em relação ao resto do mundo. $\mathrm{O}$ problema deste tipo de divisão é que os membros não estão de fato separados do resto do mundo, dado que eles estão conectados com o todo. Assim, essa divisão causa problemas e não funciona realmente. Cedo ou tarde os membros desses grupos começarão a enxergar diferenças entre si, provocando disrupções, desentendimentos e desunião. Isso porque a verdadeira unidade dos indivíduos, entre si, e com a natureza só emerge na forma de ação que não fragmenta o todo da realidade. Como afirma Bhom (2005, p. 20-21): “Como 
enfatizei, nós tentamos dividir o que é um e indivisível, e isto implica que o próximo passo será tentar identificar o que é diferente.”6

A abordagem do paradigma da complexidade é muito ampla e não caberia nas páginas deste texto, até mesmo porque não é nosso propósito realizar um estudo mais abrangente sobre o tema, mas apenas oferecer a concepção de pensamento complexo como uma alternativa para o pensamento fragmentado que direciona as nossas ações. Esse pensamento fragmentado e isolacionista é também representado pelas fake news, cujas informações disseminadas causam antagonismos, bem como pelos filtros-bolha, os quais canalizam essas informações e aglomeram separadamente esses antogonismos em espaços de interações virtuais homogêneas. A Ética da complexidade emerge do pensamento complexo, a qual tem entre suas princípais características, o princípio dialógico que, contrariamente ao isolacionismo, expressa unicidade, respeitando as diferenças e antagonismos.

Para Vasconcellos (2003, 113-114), o princípio dialógico, proposto por Morin, busca articulação entre as partes sem reduzir ou eliminar diferenças. Isso significa que não é possível alcançar a unificação primeira ou última, um princípio único, de acordo com uma perspectiva monista. O princípio dialógico expressa a articulação que mantém a dualidade na unidade, sem a busca por uma síntese, como acontece na dialética, a qual a tese e a antítese não preservam suas partes integralmente, mas se diluem na síntese. A dialógica, peça fundamental do pensamento complexo, une conceitos que são opostos e antagônicos, os quais estavam separados em contextos fechados. Um exemplo seria a afirmação de que um indivíduo é autônomo e dependente. Pensar nas duas características em negação uma à outra seria a abordagem da dialética. Na dialógica do pensamento complexo, não teríamos que escolher entre as duas características - autônomo e independente -, tampouco buscar uma caracterização que sintetize os dois aspectos do indivíduo.

Para Morin (2005, p. 209), o paradigma complexo dialógico se expressa através da implicação/distinção/conjunção. Nesse sentido, a proposta de sistema misto de Dascal vai ao encontro do paradigma da complexidade

\footnotetext{
${ }^{6}$ As pointed out, we try to divide what is one and indivisible, and this implies that in the next step we will try to identify what is different. (BOHM, 2005, p. 20-21).
} 
na medida em que, diferentemente da perspectiva mecanicista relacionada a outros vieses que separa, limita e exclui, a concepção de complexidade não está vinculada ao isolamento, à demarcação e à fragmentação do todo em partes. A proposta da complexidade, para Morin, como ressaltamos, é tratar as diferentes realidades como solidárias e conflituosas, condizentes com sistemas democráticos que alimentam e regulam antagonismos. Em relação ao sistema misto de Dascal, não se trata aqui de apoiar a colonialidade de mentes e fechar os olhos para os malefícios que o colonializador pratica com os colonializados, negando a luta e afirmando a aceitação da dominação, mas apenas entender como os movimentos do sistema, enquanto conflitos entre colonializador/colonializados, podem ser abordados pela teoria da complexidade, através da relação hologramática e dialógica de complementaridade e oposição entre partes do sistema.

No caso da colonialidade de mentes, entendemos que fake news produzem feedbacks inflacionários que amplificam as reações dos usuários das redes sociais. Isso pode ser observado nos casos citados sobre dis-information em relação às vacinas e nos casos de dis-information no processo eleitoral brasileiro, influenciando nos resultados das eleições e comprometendo o sistema democrático. A disseminação de fake news (dis-informação e malinformation) tem como um de seus principais propósitos favorecer grupos dominantes e manter o desequilíbrio de poder do sistema colonializador/colonializado.

Se consideramos que esses feedbacks inflacionários, no contexto das redes sociais virtuais, ocorrem no espaço direcionado pelos filtros-bolha, baseados na concepção de complexidade de Bhom, temos que: a divisão gerada pelos filtros-bolha, via algoritmos, induz a uma percepção ilusória de que, escondidos nas redes sociais, estamos de fato separados do resto do mundo. O problema dessa percepção ilusória é a de que ela causa problemas conjuntamente com as crenças fundamentadas em fake news que são disseminadas pela bolha. Esse problema duplo, isto é, de percepção fantasiosa de que estamos fragmentados do resto do mundo e das crenças espúrias advindas de fake news, gerará danos causados pelos membros da bolha entre si e às outras pessoas, na medida em que a fragmentação da bolha em relação ao resto do mundo não funciona realmente. Isso porque em uma bolha homo- 
gênea, mais cedo ou mais tarde, os membros perceberão diferenças entre si e isso causará desentendimento e a ruptura da bolha. A ruptura da bolha é algo positivo, principalmente em tempos de disseminação de fake news, pois a ruptura proporciona abertura para o diálogo entre posições antagônicas, favorecendo o princípio dialógico. Para Bohm, é através da ação que não fragmenta que ocorre a unidade entre indivíduos.

Não se trata aqui de demonizar o uso de algoritmos que são resultados dos avanços tecnológicos, mas apenas ressaltar que os seus aspectos negativos se concentram principalmente no que concerne ao direcionamento de informação para fins que visam prejudicar indivíduos, grupos, organizações e sistemas democráticos. Entretanto, entendemos que também há aspectos positivos quando seu uso é direcionado para fins que atendam o bem comum. $\mathrm{O}$ uso de algoritmos envolve fatores positivos que expressam sua utilidade benéfica para a sociedade, no uso para fins científicos na área médica, na previsão de doenças como câncer etc. No caso específico das redes sociais, eles podem, por exemplo, ser usados como ferramentas no empoderamento e na representatividade de grupos considerados minorias políticas, como LGBTQ+. Neste texto, o que nos concerne são os problemas gerados pela disseminação de fake news, através de redes sociais como $F a$ cebook, bem como os seus impactos negativos no espectro individual e no âmbito social relacionado, por exemplo, ao direcionamento da opinião pública e seus efeitos na política. O que criticamos é o uso de algoritmos para fins de controle e manipulação da ação individual e social, através de filtrosbolha.

O uso de algoritmos para inflar filtros-bolha cria um ambiente virtual homogêneo que restringe e exclui tudo o que se apresente como diferente, tudo o que signifique mistura. De acordo com Bauman (2011, p. 124, cap.39, Estrangeiros são perigosos. Será?), a mixofobia, medo e aversão à mistura, é manifestada nessas ilhas de similaridades e identidades em meio a um mar de diversidades e diferenças. Essas ilhas são bem representadas pelos filtros-bolha nas redes sociais virtuais. A similaridade entre os elementos da bolha não exige um olhar profundo e reflexivo sobre nós mesmos e nossas relações com o outro. A mixofobia expressa a fuga da autorreflexão e da necessidade de compreender, negociar e conciliar com o outro, com o que se 
apresenta como diferente. A superficialidade das relações estabelecidas nas redes sociais virtuais e a homogeneidade dos filtros-bolha abre um espaço amplo para a disseminação de crenças infundadas, baseadas em informações espúrias indicativas de fake news. Isso porque sem a prática do pensamento crítico advindo da autorreflexão e da reflexão em relação ao diferente, ao outro, é mais fácil disseminar fake news porque não há parâmetros de comparação para tecer críticas sólidas onde impera a homogeneidade.

Entre tantas formas de combates à disseminação de fake news, principalmente de cunho político, como afirma Bartlett, estão a educação que envolve aprendizado sobre fake news, fiscalização de agoritmos e leis que englobem a regulamentação democrática da mídia.

Entretanto, consideramos que nenhuma das decisões de combate a fake news serão eficazes se não houver a reestruturação do pensamento através do paradigma da complexidade. Essa reestruturação do pensamento envolve a percepção de que fazemos parte, segundo Morin, de uma realidade multidimensional e interligada, onde há possibilidade de organização mesmo através de elementos que geram incertezas, onde o global e o individual convivem, estabelecendo comunicação. Essa comunicação tem como uma de suas bases o princípio dialógico que une princípios antagônicos para formar o pensamento complexo. Na dialógica, segundo Morin (2005, p. 206), há a unidade complexa entre lógicas, entidades ou instâncias que se completam, mas também que se opõem. Diferentemente da dialética hegeliana, a qual as contradições buscam superar os antagonismos para chegar a uma unidade superior; na dialógica, os antagonismos permancem, gerando fenômenos ou entidades complexas.

De acordo com Morin (2005, p. 159-161; 195-198), como apontamos, através do princípio dialógico é possível a concepção de uma antropoética, caracterizada pelo padrão que liga os seres humanos nos âmbitos social, individual e genérico. A antropoética está baseada na dialógica egocentrismo/altruísmo e fortalece a parte mais subdesenvolvida, o altruísmo, abrindo espaço para ampliar a compreensão humana. Ao compartilharmos padrões e destinos comuns se torna necessário o desenvolvimento da autonomia pessoal e participação social, ampliando as responsabilidades sociais e visando o bem comum. A antropoética conjuntamente com a autoética e 
sócioética fazem parte da ética da complexidade que não impõe uma visão maniqueísta de mundo, abdicando da vingana punititivista. Para a ética da complexidade ser instaurada, é necessária a reforma do pensamento dualista, maniqueísta e mecanicista. Essa reforma acontecerá através da emergência do pensamento complexo, criando novas visões de mundo. A ética da complexidade não está fundamentada numa moralidade de garantias de regras e dogmas ditados por religiões ou partidos políticos. Não propõe a soberania da racionalidade, mas a dialógica, estabelecendo relação entre completudes e opostos, resistente ao ódio e à mentira, buscando a compreensão. Supera a dicotomia humano/natureza na medida em que concebe o ser humano não como organismo da natureza, mas como organismo na natureza, não como organismo do cosmos, mas organismo no cosmos.

De acordo com Carvalho (2002, p. 167), Morin propõe um movimento dialógico, hologramático e recursivo para explicar a complexidade das relações entre partes e todo. Nessa relação, ele procura entender o ser humano como "um vivente cosmo-psico-bio-antropossocial"; um ser biológico e cultural, pertencente à natureza e ao cosmos.

É a partir desse movimento que emerge a ética da complexidade que, como ressalta Morin, é uma ética da resistência (2005, p. 199-200):

O sentido que eu dou, enfim, à ética, caso seja necessário um termo que englobe todos os seus aspectos, é o de resistência à crueldade do mundo e à barbárie humana. A resistência à crueldade do mundo compreende a resistência ao que há de destrutor e de impiedoso na natureza; a resistência à barbárie humana é a resistência à crueldade do sapiens e ao lado negro do demens. Esse sapiens que exterminou o Neandertal da Europa. O mesmo sapiens que exterminou os índios da América, os aborígenes da Austrália e criou a escravidão, as galés, Auschwitz e o Gulag. A barbárie humana não cessou de provocar devastação e não diminuiu; encontrou nas técnicas modernas os meios de aumentar desmesuradamente o seu estrago tanto em guerras étnicas quanto em guerras de religião e de nações, que se combinam e superpõem. Os civilizados continuam a praticar genocídios e etnocídios contra povos arcaicos (índios da Amazônia, tarahumaras da Sierra Madre, México, e tantos outros denunciados por Survival International).

Para Morin (2005, p. 159), a ética da complexidade, na sua forma antropoética, expressa a indissolubidade entre sapiens/demens, atribuindo à dialógica o papel de ponderar a racionalidade e a sabedoria em detrimento da paixão e da loucura, domando as ideias autoritárias e violentas, dissemi- 
nadas, por exemplo, através fake news, bem como reconhecendo no outro a diferença e a identidade.

\section{Considerações finais}

Neste texto, analisamos como a disseminação de fake news, via tecnologias digitais, é uma das ferramentas usadas no processo de colonialidade de mentes. Com base no que foi apresentado, nossa linha de raciocínio seguiu três direcionamentos que se interconectaram:

1 - O uso desenfreado de tecnologias digitais bloqueia e mina o pensamento crítico através da ausência de solitude.

2 - Fake news servem como ferramentas para colonialidade de mentes, a qual é facilitada pela ausência do pensamento crítico e pela homogeneidade nas relações que acontecem nos filtros-bolha.

3 - A perspectiva da complexidade é uma hipótese para pensarmos uma alternativa aos estragos da colonialidade de mentes, aqui via disseminação de fake news, através do princípio dialógico e do princípio hologramático que fundamentam o desenvolvimento da ética da complexidade.

Fake news, como apontamos na seção 2, geram desconfiança e instigam conflitos entre grupos socioculturais diferentes, provocando atos violentos em nome de nacionalismos, preconceitos étnicos, religiosos, raciais, de orientação sexual, de gênero etc. Através do uso de algoritmos, as plataformas digitais, como Facebook, filtram informações e direcionam a usuários formando filtros-bolha, os quais aproximam pessoas com ideias iguais e semelhantes e afastam aquelas com ideias divergentes, aglomerando indivíduos com o mesmo viés ideológico. Como indicado por Pariser (2012), os filtros-bolha usam os fatores afinidade, tempo e conteúdo para aproximar pensamentos semelhantes e distanciar pensamentos diferentes. É através desses filtros-bolha que há o direcionamento de informações de cunho político, no caso de fake news, influenciando negativamente a opinião pública e prejudicando sistemas democráticos. Por conseguinte, faz-se necessário entender, não somente crenças que indicam fake news, mas também as crenças de quem compartilha, bem como de quem possibilita o compartilhamento. 
Vimos também que os usuários das redes sociais acabam reféns dos filtros-bolha na sua tentativa de fugir do seu medo da solidão; usando tecnologias digitais, o ser humano mergulha no mundo virtual, estando à mercê de uma quantidade imensa e imediatista de informação, parte dessas informações indicativas de fake news. Como afirma Bauman (2011), através das tecnologias digitais, o ser humano foge ilusoriamente da sua solidão que sempre o acompanhará, deixando escapar a chance de estar em solitude. Através de sua mixofobia, o ser humano busca o similar e evita as diferenças, criando ilhas (bolhas virtuais) de interações entre semelhantes.

As ilhas virtuais e a ausência de solitude é um dos motivos do atrofiamento do pensamento crítico, aprisionado pelas mídias digitais, redes sociais como Facebook. Como ressaltamos na seção 3, fake news expressam a relação colonializador/colonializado, funcionando como alimento para o processo de colonialidade de mentes. Segundo Dascal (2009), há um grande desequilíbrio ente colonializador e colonializados, às vezes percebido conscientemente, outras vezes inconscientemente. Exemplo desse desequilíbrio seria a plataforma digital Facebook, a qual segundo Bauman (2011), rouba o contato face a face, tranformando o desejo de se aprofundar no conhecimento em algo sem sentido. Esse desequilíbrio é a condição do estado de exceção tecnológica, que se instaura com a colonização digital realizada pelas Big Techs, onde nossos direitos são inexistentes ou usurpados em prol de grupos específicos, impondo a autoridade epistêmica do opressor, instrumentalizada pelas mídias dominantes. Para Dascal (2009), uma das formas de reagir à colonialidade de mentes é pensar a mistura de sistemas conflitantes, não implicando a rejeição e nem a aceitação total do colonializador.

Nossa hipótese é a de que a abordagem de Dascal sobre um sistema misto, enquanto relação entre partes conflitantes, aproxima-se da concepção do paradigma da complexidade, via princípio dialógico, o qual estabelece a relação entre opostos, superando dicotomias reducionistas e fragmentárias. Ao estabelecer a ponte entre partes conflitantes, o princípio dialógico estoura as bolhas sociais virtuais, antro de disseminação de fake news que influenciam a opinião pública e afetam sistemas políticos democráticos.

A possibilidade do estouro dessas bolhas virtuais de interação passa, como afirma Bartlett, por procedimentos que vão desde a criação de setores 
que fiscalizem a atuação de algoritmos, o oligopólio das Big Techs e a inserção na educação de temas relacionados às fake news, até o afastamento dos usuários das redes sociais virtuais como forma de diminuir a polarização e melhorar a capacidade de aceitar e lidar com opiniões divergentes.

Assim sendo, tais procedimentos abrem espaço para que o princípio dialógico se instaure como fator direcionador de relações. Ele é um dos pilares da ética da complexidade, principalmente na sua forma antropoética, desvinculando-se do pensamento dualista e mecanicista, estabelecendo caminhos para a compreensão hologramática do ser humano acerca de sua relação com o mundo.

A emergência da ética da complexidade está atrelada às reformas necessárias visando a mudança na ação e no pensamento. É necessário a reforma da sociedade (civilização), a reforma do espírito (educação) e a reforma da vida, as quais englobam a tríplice identidade humana indivíduo/sociedade/espécie. A atuação conjunta e recíproca dessas reformas abriria espaço para a instauração de democracias planetárias pautadas na substituição dos modos de organizações, baseados na centralização e hierarquia, por outros que misturariam e combinariam policentrismo e centrismo, hierarquia e anarquia, visando a consciência de um destino terrestre comum. Essas reformas também instaurariam a política da responsabilidade e solidariedade, reduzindo a hegemonia do lucro, incentivando economias plurais e solidárias. Através dessas reformas, haveria a tomada de consciência dos problemas políticos, sociais e éticos. (MORIN, 2005, p.168-173).

É no contexto desse movimento do pensamento complexo, a partir do qual emerge a concepção de ética da complexidade, que os malefícios da colonialidade de mentes perdem força, sendo substituídos por crenças que, contrariamente às fake news, geram a concepção sistêmica da natureza, de respeito as diversidades (referentes à nossa espécie e às outras espécies de animais), de responsabilidades sociais e planetárias.

\section{Referências}

AGÊNCIA BRASIL. Vazajato: Grampos nunca divulgados põem em xeque tese de Moro de que Lula pretendia travar as investigações contra ele. Agência Brasil, 8 de set. 2019. Disponível em: https://www.viomundo.com.- 
br/denuncias/grampos-nunca-divulgados-poem-em-xeque-tese-de-moro-deque-lula-como-ministro-pretendia-travar-as-investigacoes-contra-ele.html Acesso em: 19 de jan. 2020.

AVELAR, D. WhatsApp fake news during Brazil election 'favoured Bolsonaro. The Guardian, 30 de out. 2019. Disponível em: https://www.theguardian.com/world/2019/oct/30/whatsapp-fake-news-brazil-election-favouredjair-bolsonaro-analysis-suggests Acesso em: 19 de jan. 2020.

BALTHAZAR, R.; BÄCHTOLD, F.; LARA, B.; BIANCHI, P.; DEMORI, L. Leia diálogos da Lava Jato sobre escutas telefônicas do ex-presidente Lula. Folha de S. Paulo, São Paulo, 8 de set. 2019. Disponível em: https:// www1.folha.uol.com.br/poder/2019/09/leia-dialogos-da-lava-jato-sobreescutas-telefonicas-do-ex-presidente-lula.shtml Acesso em: 19 de jan. 2020.

BARROS, G. Veja o que é \#FATO e o que é \#FAKE sobre imunização. $O$ Globo, Rio de Janeiro, 31 de jul. 2018. Disponível em: https://gl.globo.com/fato-ou-fake/noticia/2018/07/31/veja-o-que-e-fato-e-o-que-e-fakesobre-imunizacao.ghtml Acesso em: 19 de jan. 2020.

BAUMAN, Z. 44 cartas do mundo líquido moderno. Rio de Janeiro: Jorge Zahar Editor, 2011.

BBC. A mãe que perdeu 2 filhos para o sarampo por acreditar em 'fake news' sobre vacinas. BBC, São Paulo, 21 de jun. 2019. Disponível em:https://g1.globo.com/ciencia-e-saude/noticia/2019/06/21/a-mae-que-perdeu-2-filhos-para-o-sarampo-por-acreditar-em-fake-news-sobre-vacinas.g \%E2\%80\%A6 Acesso em: 19 de jan. 2020.

BOGHOSSIAN, B. Entenda como as mensagens da Lava Jato podem afetar os processos da operação. Folha de S. Paulo, São Paulo, 9 de ago. 2019. Disponível em: https://www1.folha.uol.com.br/poder/2019/08/entendacomo-as-mensagens-da-lava-jato-podem-afetar-os-processos-da-operacao.shtml Acesso em: 19 de jan. 2020.

BOHM, D. Unfolding Meaning: a weekend of dialogue.New York:Routlege, 1996.

BOHM, D. Wholeness and the impicate order. New York: Routledge, 2005.

BRANCO, S. Fake News e os Caminhos para Fora da Bolha. In: Interesse Nacional, São Paulo, ano 10, n. 38 , 2017, p. 51-61. Disponível em: https:// itsrio.org/wp-content/uploads/2017/08/sergio-fakenews.pdf Acesso em: 18 de jan. 2020.

BRASIL 247. Para defender vazamento ilegal de áudio entre Dilma e Lula, Deltan articulou nota da ANPR. Brasil 247, São Paulo, 21 de set. 2019. Disponível em: https://www.brasil247.com/brasil/para-defender-vazamentode-audio-entre-dilma-e-lula-deltan-ajudou-o-presidente-da-anpr-a-redigirnota Acesso em: 19 de jan. 2020. 
BRASIL 247. Facebook anuncia que vai continuar permitindo divulgação de fake news em anúncios políticos. Brasil 247, São Paulo, 9 de jan. 2020. Disponível em: https://www.brasil247.com/midia/facebook-anuncia-quevai-continuar-permitindo-divulgacao-de-fake-news-em-anuncios-politicos Acesso em: 19 de jan. 2020.

BRUM, E. Pesquisa revela que Bolsonaro executou uma "estratégia institucional de propagação do coronavírus". El País, 21 de ja. 2021. Disponível em: https://brasil.elpais.com/brasil/2021-01-21/pesquisa-revela-que-bolsonaro-executou-uma-estrategia-institucional-de-propagacao-do-virus.html Acesso em: 15 de março de 2021.

CARVALHO, E. A. Edgar Morin, a dialogia de um Sapiens-demens. In: Margem, São Paulo, n. 16, p. 167-170, 2002. Disponível em: https://www.pucsp.br/margem/pdf/m16ec.pdf Acesso em: 29 de jan. 2020.

CASTRO, F.; NUNES, S.; NETTO, V. Moro derruba sigilo e divulga grampo de ligação entre Lula e Dilma; ouça. G1, Rio de Janeiro, 16 de mar. 2016. Disponível em: http://g1.globo.com/pr/parana/noticia/2016/03/pflibera-documento-que-mostra-ligacao-entre-lula-e-dilma.html Acesso em: 19 de jan. 2020.

CONVERSA AFIADA. Guardian mostra como as fake news elegeram Bolsonaro. Conversa Afiada, São Paulo, 30 de out. 2019. Disponível em: https://www.conversaafiada.com.br/politica/guardian-mostra-como-as-fakenews-elegeram-bolsonaro Acesso em: 19 de jan. 2020.

DASCAL, M. Colonizing and decolonizing minds. 2009. Disponível em: https://philpa-pers.org/rec/DASCAD Acesso em: 30 de out. 2019.

EDUCAÇÃO EM AÇÃO. Análise do Discurso - Discurso e Ideologia (Michel Pêcheux). You Tube, 28 de nov. 2015. Disponível em: https://www.youtube.com/watch?v=No2yqmNTCp4 Acesso em 26 de jan. 2020.

FALSO. In: Dicio, dicionário online de português. Disponível em: https:// www.dicio.com.br/falso/. Acesso em 26 de jan. 2020.

FANON, F. O. Os condenados da terra. Lisboa: Ulisseia, 1965.

FANON, F. Pele negra, máscaras brancas. Salvador: EDUFBA, 2008. Disponível em: https://www.geledes.org.br/wp-content/uploads/2013/08/ Frantz_Fanon_Pele negra mascaras brancas.pdf Acesso em 27 de jan. 2020 .

G1. Facebook tem sido menos usado para ler notícias, enquanto WhatsApp cresce. G1, Rio de Janeiro, 15 de jun. 2018. Disponível em: https://g1.globo.com/economia/tecnologia/noticia/facebook-tem-sido-menos-usado-paraler-noticias-enquanto-whatsapp-cresce.ghtml Acesso em: 19 de jan. 2020. 
G1. Facebook compra o aplicativo WhatsApp por US\$ 16 bilhões. G1, São Paulo, 19 de fev 2014. Disponível em: http://g1.globo.com/tecnologia/noticia/2014/02/facebook-compra-o-aplicativo-whatsapp-por-us-16-bilhoes.html Acesso em: 19 de jan. 2020.

GALILEU. Responsável pela imagem de buraco negro é alvo de ataques machistas. Galileu, 13 de abr. 2019. Disponível em: https://revistagalileu.globo.com/Ciencia/noticia/2019/04/responsavel-pela-imagem-de-buraconegro-e-alvo-de-ataques-machistas.html Acesso em: 19 de jan. 2020.

GALLO, S. L.; FLORES, G. B.; PINOTTI, A.; SOUZA, C. R. Ler o arquivo hoje. Disponível em: http://www.analisedodiscurso.ufrgs.br/anaisdosead/ 1SEAD/Paineis/AngelaPinotti.pdf Acesso em: 19 de jan. 2020.

GIMENO, R. O que acontece com seu cérebro se você largar o Facebook? El País, 13 de fev. 2019. Disponível em: https://brasil.elpais.com/brasil/ 2019/02/12/tecnologia/1549990082 118422.html Acesso em: 20 de jan. 2020 .

GUIMARÃES, K. Vacinação em queda no Brasil preocupa autoridades por risco de surtos e epidemias de doenças fatais. $B B C$, São Paulo, 29 de ago. 2017. Disponível em: https://www.bbc.com/portuguese/brasil-41045273 Acesso em: 20 de jan. 2020.

JUCÁ, B. Chip na vacina, "virar jacaré" e outros mitos criam pandemia de desinformação na luta contra a covid-19. El País, 21 de dez. 2020. Disponível em: https://brasil.elpais.com/brasil/2020-12-20/chip-na-vacina-virarjacare-e-outros-mitos-criam-pandemia-de-desinformacao-na-luta-contra-acovid-19.html Acesso em: 15 de março de 2021.

KWET, M. Digital colonialism: The evolution of US empire. In: TNI Longreads, 4 de mar. 2021. Disponível em: https://longreads.tni.org/digitalcolonialism-the-evolution-of-us-empire Acesso em: 17 de março de 2021.

LAMPOGLIA, F.; DA SILVA, J. R. B.; BASTOS, G. G.; ABRAHÃO E SOUSA, L. M. Gol-pe ou revolução?um jogo discursivo na mídia. In: Entremeios: revista de estudos do discurso. v.12, 2016 Disponível em: http:// www.entremeios.inf.br. Acesso em: 21 de Nov. 2019.

MARICONDA, P. R. Tecnologia, Ignorância e Violência. In: Outras Palavras, 17 de jul. 2019. Disponível em: https://outraspalavras.net/tecnologiaemdisputa/tecnologia-ignorancia-e-violencia/ Acesso em: 20 de jan. 2020.

MATOS, T. Pesquisa Datafolha: 1 em cada 5 brasileiros compartilha notícias de política em Facebook e WhatsApp. G1, Rio de Janeiro, 23 de ago. 2018. Disponível em: http://g1.globo.com/economia/tecnologia/noticia/ 2018/08/23/pesquisa-datafolha-1-em-cada-5-brasileiros-compartilha-noticias-de-politica-em-fac\%E2\%80\%A6/ Acesso em: 20 de jan. 2020. 
MEMMI, A. The Colonizer and the Colonized. Boston, MA: Beacon Press[original French edition, with a prologue by Jean-Paul Sartre, 1957], 1967.

MEMMI, A. Decolonization and the Decolonized. Minneapolis, MN: Universityof Minnesota Press [original French edition, 2004], 2006.

MONIZ, G.; BENITES, A. Áudio com diálogo de Lula e Dilma leva milhares de manifestantes às ruas. El País Brasil, 18 de marc. 2016. Disponível em: https://brasil.elpais.com/brasil/2016/03/17/politica/ 1458179601_208300.html Acesso em: 20 de jan. 2020.

MOREIRA, V. L.; SOUSA ROMÃO, L. M. O discurso no Twitter, efeitos de extermínioem rede. In: Revista Rua, Campinas, N. 17, V. 2 , p. 77-97, 2011. Disponível em: https://www.labeurb.unicamp.br/rua/anteriores/ pages/pdf/17-2/5-17-2.pdf Acesso em: 21 deNov 2019.

MORIN, E. Introdução ao pensamento complexo. Lisboa: Instituto Piaget, 1995.

MORIN, E. Os sete saberes necessários à educação do futuro. Disponível em: http://portal.mec.gov.br/seb/arquivos/pdf/EdgarMorin.pdf Acesso em: 21 deNov 2019.

MORIN, E. Ciência com consciência. Rio de Janeiro: Bertrand Brasil. 2005.

MORIN, E. O método 1. a natureza da natureza. Portugal: Publicações Europa-América, 1977.

MORIN, E. O método 6. Ética. Porto Alegre: Sulina, 2005.

MORIN, E. A cabeça bem-feita. Rio de Janeiro: Sindicato Nacional dos Editores de Livros, 2003.

MORIN, E. Da necessidade de um pensamento complexo. Disponível em: http://www.rogerioa.com/resources/Cult1/necessidade.pdf Acesso em: $20 \mathrm{de}$ jan. 2020.

MORONI, J. Possíveis Impactos de Fake News na Percepção-Ação Coletiva. Complexitas - Rev. Fil. Tem. Belém, v. 3, n. 1, p. 130-160, jan./jun. 2018. Disponível em: https://periodicos.ufpa.br/index.php/complexitas/article/view/6625/pdf. Acesso em: 20 de fevereiro de 2019.

PAIVA, D.; LAVADO, T. Vídeos de YouTube com informações falsas somam milhões de visualizações e alimentam debate político no WhatsApp. G1, Rio de Janeiro, 19 de jan. 2020. Disponível em: https://g1.globo.com/ politica/noticia/2020/01/19/videos-de-youtube-com-informacoes-falsassomam-milhoes-de-visualizacoes-e-alimentam-deba $\% \mathrm{E} 2 \% 80 \% \mathrm{~A} 6$ Acesso em: 20 de jan. 2020. 
PARISER, E. O filtro invisivel. Rio de Janeiro: Jorge Zahar Editor, 2011.

PINHEIRO, C. Aranto mata células do câncer e pode servir de tratamento? Não é bem assim. Veja Saúde, 4 de mar. 2020. Disponível em: https://saude.abril.com.br/blog/e-verdade-ou-fake-news/aranto-mata-celulas-do-cancer-e-pode-servir-de-tratamento-nao-e-bem-assim/ Acesso em: 15 de março de 2021.

PÚBLICA. Vaza Jato. Disponível em: https://apublica.org/especial/vazajato/ Acesso em: 15 de março de 2021.

RECUERO, R.; GRUZD, A. Cascatas de Fake News Políticas: um estudo de caso no Twitter. In: Galaxia (São Paulo, online), n. 41, 2019, p. 31-47. Disponível em: http:/www.scielo.br/pdf/gal/n41/1519-311X-gal-41-0031.pdf Acesso em: 20 de jan. 2020.

RIBEIRO, F. Facebook não vai alterar regras para anúncios políticos em 2020. Yahoo, 13 de jan. 2020. Disponível em: https:// br.noticias.yahoo.com/facebook-não-vai-alterar-regras-172000701.html Acesso em: 20 de jan. 2020.

RIBEIRO, A. Como Greta Thunberg se tornou alvo de uma campanha de desinformação nas redes. Aos Fatos, 27 de set. 2019. Disponível em: https://aosfatos.org/noticias/como-greta-thunberg-se-tornou-alvo-de-umacampanha-de-desinformacao-nas-redes/ Acesso em: 19 de jan. 2020.

RUDNITZKI, E. Como a internet está matando a democracia. Pública, 19 de março 2019. Disponível em: https:/apublica.org/2019/03/como-a-internet-esta-matando-a-democracia/ Acesso em: 19 de jan. 2020.

SANTOS, Vívian Matias dos. Notas desobedientes: decolonialidade e a contribuição para a crítica feminista à ciência. Psicol. Soc., Belo Horizonte , v. 30, e200112, 2018 . Disponível em: https://www.scielo.br/scielo.php? script=sci_arttext\&pid=S0102-71822018000100242 Acesso em: 15 de março de $202 \overline{1}$.

SOLIDÃO. In: Michaelis. Disponível em: http://michaelis.uol.com.br/busca?id=ZNayj Acesso em: 19 de jan. 2020.

SOLITUDE. In: Dicio - dicionário online e português. Disponível em: https://www.dicio.com.br/solitude/ Acesso em: 19 de jan. 2020.

TEODORO, P. Vazamento seletivo de grampo com Dilma comprova prepotência, ódio e perseguição da Lava Jato a Lula. Forum, 8 de set. 2019. Disponível em: https://revistaforum.com.br/politica/vaza-jato/vazamento-seletivo-de-grampo-com-dilma-comprova-prepotencia-odio-e-perseguicao-dalava-jato-a \%E2\%80\%A6 Acesso em: 19 de jan. 2020. 
THE INTERCEPT BRASIL. As mensagens secretas da Lava Jato. Disponível em: https://theintercept.com/series/mensagens-lava-jato/ Acesso em: 15 de março de 2021.

TILLLICH, P. The eternal flow. New York: Charles Scribner's Sons, 1963. Disponível em: https://mercaba.org/SANLUIS/Filosofia/autores/Contempor \%c3\%a1nea/Tillich/The\%20eternal\%20now.pdf Acesso em: 24 de jan. 2020 .

UOL. Katie Bouman sofre onda de ataques machistas na internet e colega a defende. Uol, 12 de abr. 2019. Disponível em: https://www.uol.com.br/universa/noticias/redacao/2019/04/12/colega-de-katie-bouman-a-defende-aposonda-de-ataques-machistas-na-internet.htm Acesso em: 24 de jan. 2020.

VALENTE, J. Redes sociais perdem espaço como fonte de notícia,diz relatório global. Agência Brasil, 15 de jun. 2018. Disponível em: http://agenciabrasil.ebc.com.br/geral/noticia/2018-06/redes-sociais-perdem-espaco-comofonte-de-noticiadiz-relatorio-global Acesso em: 18 de jan. 2020.

VASCONCELLOS, M. J. E. Pensamento sistêmico: o novo paradigma da ciência. Campinas: Papirus Editora, 2003.

VIOMUNDO. Vazajato: Grampos nunca divulgados põem em xeque tese de Moro de que Lula pretendia travar as investigações contra ele. Viomundo, 8 de set. 2019. Disponível em: https://www.viomundo.com.br/denuncias/ grampos-nunca-divulgados-poem-em-xeque-tese-de-moro-de-que-lulacomo-ministro-pretendia-travar-as-investigacoes-contra-ele.html Acesso em: 26 de jan. 2020.

WALSH, C. Intercuturalidade, Estado, Sociedad: Luchas (de)coloniales de nuestra época. Quito: Universidad Andina Simón Bolívar; Ediciones AbyaYala, 2009.

WARDLE, C.; DERAKHSHAN, H. Information Disorder: Toward an interdisciplinary framework for research and policymaking. Strasbourg: the Council of Europe, 2017. Disponível em: https://rm.coe.int/informationdisorder-toward-an-interdisciplinary-framework-for-researc/168076277c . Acesso em: 24 de jan. 2020. 